\title{
Breeding behavior, distribution, and conservation of the Sharp-tailed Tyrant Culicivora caudacuta (Vieillot, 1818) (Aves: Tyrannidae), a South American grassland specialist
}

\author{
Robson Silva e Silva ${ }^{1}$ \\ ${ }^{1}$ Independent Researcher. Santos, SP, Brasil. ORCID: http://orcid.org/0000-0002-4086-7106. E-mail: rsilvaesilva@uol.com.br
}

\begin{abstract}
Culicivora caudacuta occurs in the Cerrado, Pampa and Chaco grasslands of Bolivia, Brazil, Paraguay, Argentina and Uruguay. Its breeding biology is poorly known. Here, I present a summary of the published information and new data gathered between 2003 and 2009 in southeast Brazil at Tapira, Minas Gerais. Breeding occurred during the rainy season (October to March), clutch size being three eggs. Juveniles and immatures show a different plumage from the adults, mostly brownish orange. All nests studied at Tapira showed evidence of cooperative breeding, with one helper engaged in incubation and provisioning the young. This is the first observations of this behavior for the species. The species has a wider range than currently understood and its presence in protected areas is similarly more common.
\end{abstract}

Keywords. Nest description; Cooperative breeding; Eggs; Young plumage; Records.

\section{INTRODUCTION}

The Sharp-tailed Tyrant Culicivora caudacuta (Fig. 1) is a small tyrant flycatcher (Tyrannidae: Elaeniinae) described in 1818 by Louis Jean Pierre Vieillot (1748-1830) as Muscicapa caudacuta (Le Moucherolle a queue en aiguille), based on the original description of the "Cola de agujas" (№ 277) from Paraguay by Félix de Azara (1746-1821) (Vieillot, 1818). Later, in 1822, Coenraad Jacob Temminck (1778-1858) described the same bird under the name Muscicapa stenura (Gobe-Mouche a queue grêle), with an illustration (Fig. 2) based on specimens (Fig. 3) collected in Brazil (São Paulo state) during the expedition of the Austrian naturalist Johann Natterer (1787-1843) (Temminck, 1822; Cory \& Hellmayr, 1927).

Culicivora caudacuta occurs in central South America in habitats dominated by tall grasses and bushes in the Cerrado, Chaco and Pampa of Bolivia, Brazil, Paraguay, Argentina and Uruguay (Azpiroz, 1998; Fitzpatrick, 2004; Lopes et al., 2009).

Brazil accounts for most of the species' range, with records in the states of Amazonas, Maranhão, Tocantins, Bahia, Mato Grosso, Mato Grosso do Sul, Goiás, Distrito Federal, Minas Gerais, São Paulo, Paraná, Santa Catarina, and Rio Grande do Sul (Lopes et al., 2009; WikiAves, 2020).
There are few studies of its biology and breeding behavior, the first data being gathered in Argentina in the early $20^{\text {th }}$ century (Hartert \& Venturi, 1909), with little published since then. Most of the available information refers to breeding records and the presence of nests, young or immatures in the Brazilian states of Tocantins (Dornas \& Pascoal, 2019), Distrito Federal (Marini et al., 2012), Goiás (Hass \& Silva e Silva, 2008), Minas Gerais (Ribon et al., 1995; Silveira, 1998; Lombardi et al., 2010; Peixoto, 2014), Santa Catarina and Rio Grande do Sul (Fontana et al., 2003; Rovedder et al., 2007; Fontana et al., 2008; Repenning et al., 2010), and in Paraguay in Itapúa Department (Smith, 2017).

More detailed data on the breeding biology of $C$. caudacuta were gathered at the Distrito Federal (Braz, 2008; Sousa \& Marini, 2007), Goiás (Braz, 2008) and Minas Gerais (Silva e Silva, 2006) in Brazil, and Formosa (Di Giacomo, 1996, 2005; Di Giacomo et al., 2011) in Argentina.

Here I summarize all the available information on the distribution and breeding biology of C. caudacuta, and add new data mostly based on observations carried out at Tapira, Minas Gerais state, southeast Brazil, with the first observations of cooperative breeding by this species. 


\section{MATERIAL AND METHODS}

\section{Study area}

The main study area is in the municipality of Tapira, southeast Minas Gerais, on the property of Fosfertil (now Mosaic Fertilizantes) known as Tapira Mining Complex (Complexo de Mineração de Tapira - CMT). This covers an area of 7,150.86 ha, including the largest phosphate mining operation in Latin America, with elevations from 950 to $1,300 \mathrm{~m}$ a.s.l. The area has several tailing dams (BDs) built to receive the discards from the mining process and protect the watershed downstream from the CMT (Santos et al., 2002). One of these dams, BD-5 (Fig. 4) (1949'36"S, $46^{\circ} 50^{\prime} 14^{\prime \prime} \mathrm{W}$, elevation 1,160 m), covers an area of $46 \mathrm{ha}$, and was formed by the damming of the Potreiro and Boa Vista creeks, showing varied aquatic habitats with cattails Typha domingensis (Typhaceae), muddy shores and open-water areas with different depths.

This dam is surrounded by open Cerrado, with campos limpos (open grasslands) and campos sujos (grasslands with scattered bushes) showing a mix of invasive exotic grasses such as Melinis minutiflora (Poaceae) and Brachiaria decumbens (Poaceae), and native ones as Echinolaena inflexa (Poaceae), with scattered bushes, such as Baccharis dracunculifolia (Asteraceae) and Solanum lycocarpum (Solanaceae), among others.

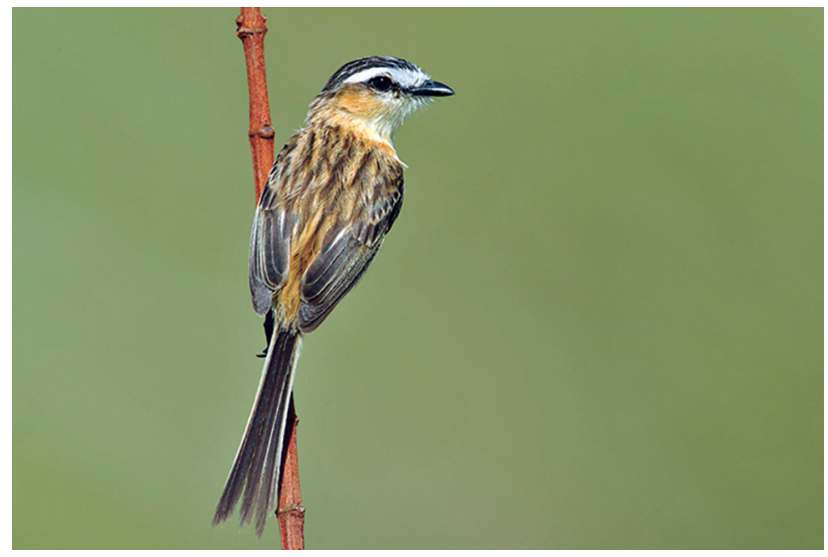

Figure 1. Adult Sharp-tailed Tyrant Culicivora caudacuta, (11 0ctober 2011), Patrocínio, Minas Gerais, Brazil. Photo: RSS.

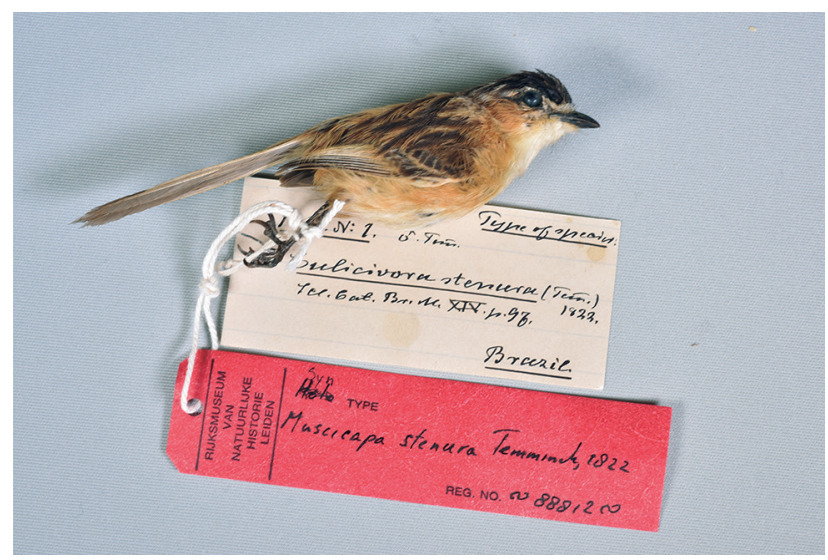

Figure 3. Specimen (RMNH 88812) of Culicivora caudacuta used in Temminck's description. Photo: RSS.
Around the BD-5, as in the vicinity of Tapira and Araxá, there are also a few remnants of Atlantic Forest fragments, especially along watercourses, and a few plantations of Eucalyptus sp. (Myrtaceae).

The grasslands around BD-5 shelter several bird species typical of the Cerrado including Red-winged Tinamou (Rhynchotus rufescens), Spotted Nothura (Nothura maculosa), Dwarf Tinamou (Taoniscus nanus), Ocellated Crake (Micropygia schomburgkii), Red-legged Seriema (Cariama cristata), Collared Crescentchest (Melanopareia torquata), Crested Black-Tyrant (Knipolegus lophotes), Sedge Wren (Cistothorus platensis), Grassland Sparrow (Ammodramus humeralis), Blue Finch (Porphyrospiza caerulescens), Stripe-tailed Yellow-Finch (Sicalis citrina), Wedgetailed Grass-Finch (Emberizoides herbicola), Plumbeous Seedeater (Sporophila plumbea), and Black-masked Finch (Coryphaspiza melanotis). This assemblage, as well as general habitat and setting, are very similar to those at Serra da Canastra National Park (Silveira, 1998), only 25 km away.

Besides the BD-5, Culicivora caudacuta was also found and studied in another two areas in the CMT, one in the $1,430.20$ ha legal reserve upstream from the dam (19 $51^{\prime} 44^{\prime \prime} \mathrm{S}, 46^{\circ} 47^{\prime} 52^{\prime \prime} \mathrm{W}$, elevation 1,250 m), an area with very similar habitat, and near Ribeirão do Inferno, another similar area covering 510 ha partially included in the municipality of Araxá (1946'22"S, 46 $52^{\prime} 48^{\prime \prime} \mathrm{W}$, elevation $1,240 \mathrm{~m})$.

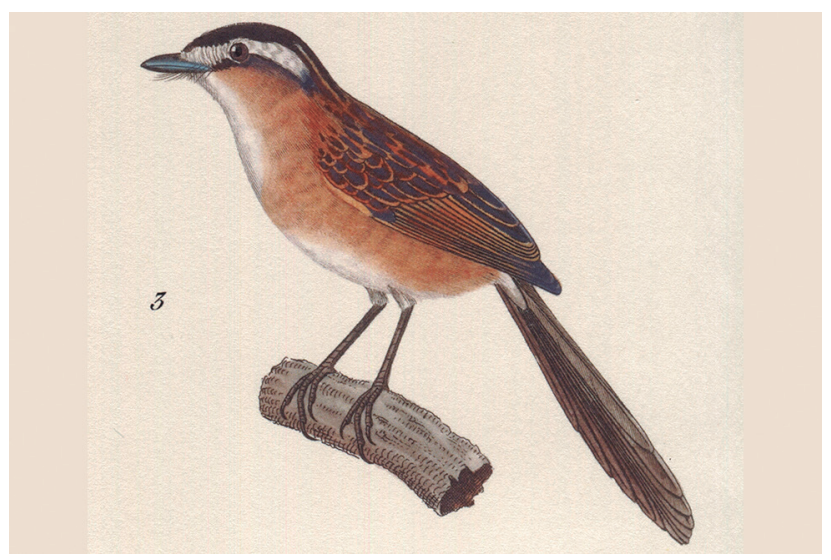

Figure 2. Illustration of Muscicapa stenura (Culicivora caudacuta), by JeanGabriel Prêtre, in Temminck's work, with a wrongly drawn tail.

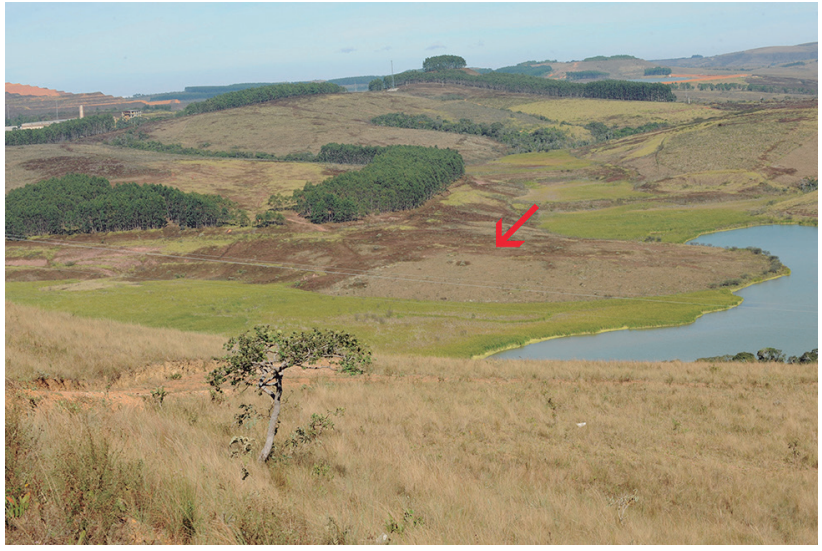

Figure 4. Partial view of BD-5 showing the study site at CMT, Tapira, Minas Gerais (18 June 2009). The arrow shows where nests were found. Photo: RSS. 
Dairy ranching is the main economic activity in the region where CMT is located but grazing animals are excluded from the dam area and the legal reserve. Grazing has transformed the native grasslands in open landscapes dominated by African grasses with some remnant native plants. Fires for "pasture renovation" are frequent and have a direct impact on the avifauna, especially grassland-dependent species.

Supplementary observations on the breeding biology of $C$. caudacuta were made in two additional areas. The first was in the municipality of Patrocínio, in the Triângulo Mineiro and Alto Paranaíba region of Minas Gerais, about $100 \mathrm{~km}$ from CMT. There the species was recorded more frequently in the headwaters of the Córrego Bebedouro $\left(19^{\circ} 00^{\prime} 06^{\prime \prime} \mathrm{S}, 46^{\circ} 46^{\prime} 07^{\prime \prime} \mathrm{W}\right.$, elevation 1,012 m), an area belonging to Mosaic Fertilizantes, and in the headwaters of the Córrego do Mato $\left(19^{\circ} 09^{\prime} 37^{\prime \prime} \mathrm{S}, 46^{\circ} 55^{\prime} 28^{\prime \prime} \mathrm{W}\right.$, elevation 1,005 m), Córrego do Fundão $\left(19^{\circ} 06^{\prime} 49^{\prime \prime} \mathrm{S}, 46^{\circ} 54^{\prime} 07^{\prime \prime} \mathrm{W}\right.$, elevation 1,184 m), and Córrego Capoeira Grande (19¹1'42"S, 46 $55^{\prime} 56^{\prime \prime} \mathrm{W}$, elevation 1,049 m).

The second area, also in Minas Gerais, in the municipality of Paracatu, includes the headwaters of the Ribeirão Batalha $\left(17^{\circ} 29^{\prime} 48^{\prime \prime} \mathrm{S}, 47^{\circ} 15^{\prime} 48^{\prime \prime} \mathrm{W}\right.$, elevation $880 \mathrm{~m}$ ) at the border with Goiás state and the municipality of Catalão, about $260 \mathrm{~km}$ from CMT. The area has remnant veredas dominated by Mauritia palm swamps bordered by hydromorphic grasslands on undulated terrain and grasslands with mounds built by termites campos de murunduns in a landscape where most native vegetation has been replaced by soybean monoculture.

\section{Sampling}

The research done at CMT was part of a broader project to survey the avifauna in areas belonging to Fosfertil in Minas Gerais and Goiás. I made two-day visits every month totalling 158 days between June 2002 and October 2011. Observations were made ad libitum (Altmann, 1974) from sunrise to sunset over the entirety of the areas.

At Patrocínio I made monthly two-day visits between 2007 and 2012, 15 days in August 2020, and 16 days in May-June 2021 totalling 114 days, while at Ribeirão Batalha I made occasional visits between 2004 and 2009 with a total of 28 days.

Territorial groups at CMT were mist-netted in 2005, and as C. caudacuta would easily pass through the mesh I used a speaker to attract the birds while an assistant held the pole supporting one extremity of the net, closing it once a bird hit the net.

Netted birds received both metal rings from CEMAVE (Brazil's official ringing scheme) and colour rings to allow individual identification. Bill, tail, tarsus, wing chord, nests and eggs were measured with a digital Mitutoyo ${ }^{\circledR}$ caliper; birds and eggs were weighted with Pesola ${ }^{\circledR}$ spring scales. All measurements are in $\mathrm{mm}$, and when necessary other units are used.

Birds and their nests were found by active search with playback in suitable habitat inside CMT, especially near
BD-5, where the birds were more habituated to human presence and, when nests were located, monitoring caused little interference in their behavior. Nests were not tagged with tape or other markers to avoid attracting predators.

Additional data on the breeding biology and localities were gathered from records at Wikiaves (http://www. wikiaves.com.br), xeno-canto (http://www.xeno-canto. org), Macaulay Library (http://www.macaulaylibrary.org), eBird (http://www.ebird.org), and from personal communications by fellow researchers.

\section{RESULTS AND DISCUSSION}

\section{Breeding behavior}

\section{Breeding season}

Culicivora caudacuta was first recorded at CMT on 26 November 2002 at BD-5, the same spot where nests were found, and in another two areas along the reservoir.

At CMT, the breeding season occurs from October to March (Silva e Silva, 2006), considering the time the first nests were found to the latest date fledglings were fed by their parents. The actual start of the nesting period is probably September since nest building take 10 to 15 days (Di Giacomo, 2005).

At Águas Emendadas Ecological Station, Central Brazil, the breeding season was bracketed between October and April, based on the presence of brooding patches, active nests and records of young being fed by adult birds (Sousa \& Marini, 2007; Marini et al., 2012). Not far away, at Chapada dos Veadeiros National Park, also in Central Brazil, breeding runs from mid-October to late March (Braz, 2008).

In Formosa, northwestern Argentina, nests were active between October and March, with no information on the time when fledglings were attended by adults ( $\mathrm{Di}$ Giacomo, 1996, 2005; Di Giacomo et al., 2011).

Culicivora caudacuta, as most species breeding at this time of the year, starts nesting at the end of the dry season when the first rains begin in September (Marini et al., 2012), as the rainy season is associated with greater abundance of food, especially insects, to feed the young.

\section{The nest}

The first nest (Nest 1) was found on 8 December 2003 at CMT, on the left bank of BD-5 (19 $\left.49^{\prime} 34^{\prime \prime} \mathrm{S}, 46^{\circ} 50^{\prime} 28^{\prime \prime} \mathrm{W}\right)$ when the fledglings were being attended by the parents (see below). It was a small and delicate, deep cup made of coarser plant fibres, flowers and cotton-like material bound with spider webs and lined with soft material. It was ca. $0.7 \mathrm{~m}$ above ground on the branches of a Baccharis dracunculifolia (Asteraceae) bush ca. $1.40 \mathrm{~m}$ high. The nest was 48.79 high, 40.55 deep, had an external diameter of 51.34. The empty nest was collected and is in the ornithological collection of the Museu de Zoologia da Universidade de São Paulo (MZUSP), São Paulo, Brazil. 
Nest 2 (Fig. 5) was found on 8 November 2004, only $88 \mathrm{~m}$ from Nest 1, in the same area of BD-5 (Fig. 6). It had two very young nestlings and was also built on a $B$. dracunculifolia, at $1.30 \mathrm{~m}$ above ground.

Nest 3 was found on 25 October 2005 in the same area, $48 \mathrm{~m}$ from Nest 1 and $40 \mathrm{~m}$ from Nest 2. It contained three eggs and was built $0.45 \mathrm{~m}$ above ground on a Campomanesia sp. (Myrtaceae) shrub about $0.90 \mathrm{~m}$ tall. Measurements were height 48.63, internal depth 40.93, external diameter at the rim 50.55, internal diameter 49.04.

Nest 4 was found still empty on 10 October 2008 (Fig. 7). It was built on a Vernonanthura cf. polyanthes (Asteraceae), also at BD-5 but was not monitored for long as on 27 October it looked unkempt and abandoned, apparently due to predation.

At Ribeirão Batalha, on 28 November 2007, one adult was seen collecting the soft fibres (Fig. 8), likely for a nest that was not located. This strongly suggests the bird was breeding, as Di Giacomo (2005) points the adults continue to bring nest material throughout laying and incubation.

At Chapada dos Veadeiros, another nest was found while still being built on 3 September 2007, at Fazenda

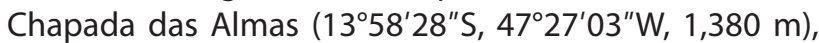
near the Rio das Almas, Alto Paraíso de Goiás, Goiás. This was in a wet grassland dominated by grasses some $40 \mathrm{~cm}$ tall with scattered bushes $c a .1 \mathrm{~m}$ tall by a riverine forest. Built ca. $85 \mathrm{~cm}$ above ground on a bush, the nest had grass seeds lining its structure, which was held to-

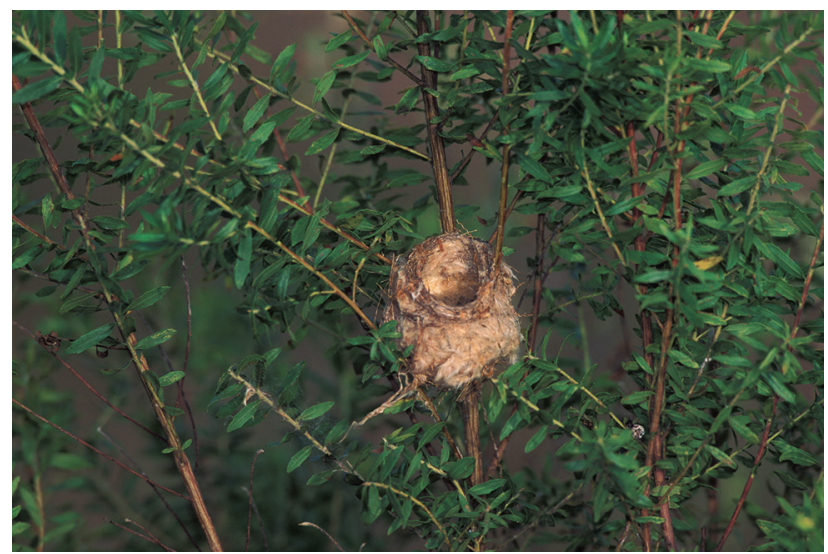

Figure 5. Nest 2, 9 November 2004. Photo: RSS.

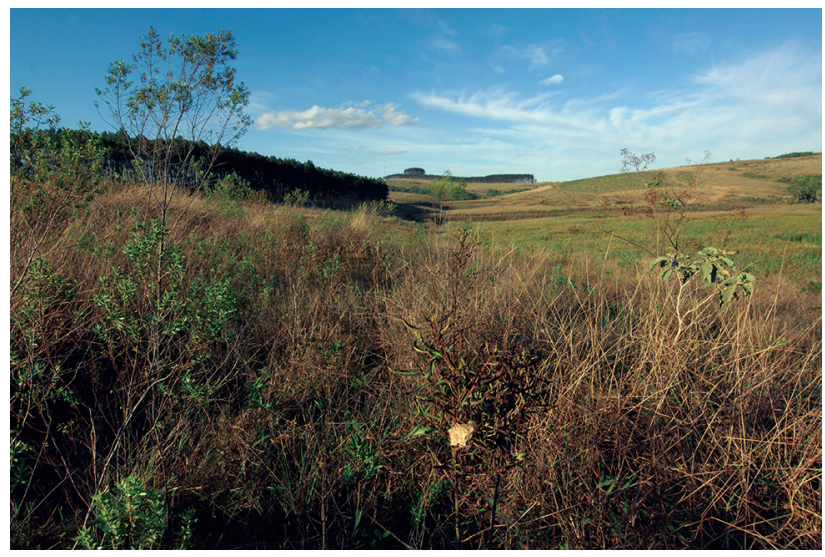

Figure 7. Nest site of Nest 4 in the same area, 110 ctober 2008. Photo: RSS. gether and attached to the branches with spider webs. (Dante Buzzetti pers. comm. May 2020).

Nests found at our study areas agree with descriptions from the Argentine Chaco (Hartert \& Venturi, 1909), Formosa Province (Di Giacomo et al., 2005), Central Brazil (Braz, 2008; Marini et al., 2012), Minas Gerais (Lombardi et al., 2010), and Rio Grande do Sul (Rovedder et al., 2007). In all areas, nests were half-spherical, deep, solid cups made of fine plant material bound with spider silk and lined with soft material, especially fine fibres from Asteraceae seeds. They were built among the vertical branches of low bushes, mostly less than $1 \mathrm{~m}$ above ground.

The exception to the use of bushes seems to be the nest built close to the ground in a grass tussock found by Hass \& Silva e Silva (2008) at Emas National Park, Central Brazil, suggesting some degree of plasticity. The same behavior was recorded by Lombardi et al. (2012) at Carrancas, Minas Gerais, in October 2009.

Peixoto (2014) also recorded an adult carrying cotton-like soft fibres to its nest on 12 October 2013 at Andrelândia, Minas Gerais, in grassland with shrubs.

The first published description of a C. caudacuta nest, from the Chaco of Santa Fe province, Argentina, was made in the early $20^{\text {th }}$ century (Hartert $\&$ Venturi, 1909). The nest, with three eggs, was built on a low spiny bush of a kind growing sparsely in the grasslands; it was solidly built with grass flowers and soft fibres neatly organised and lined with softer material. Its measurements were:

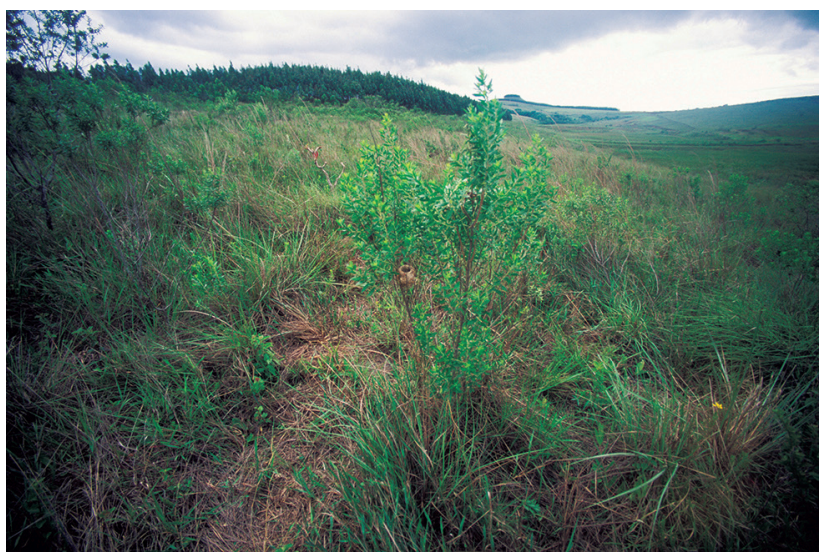

Figure 6. Nest site of Nest 1, 8 December 2003. Photo: RSS.

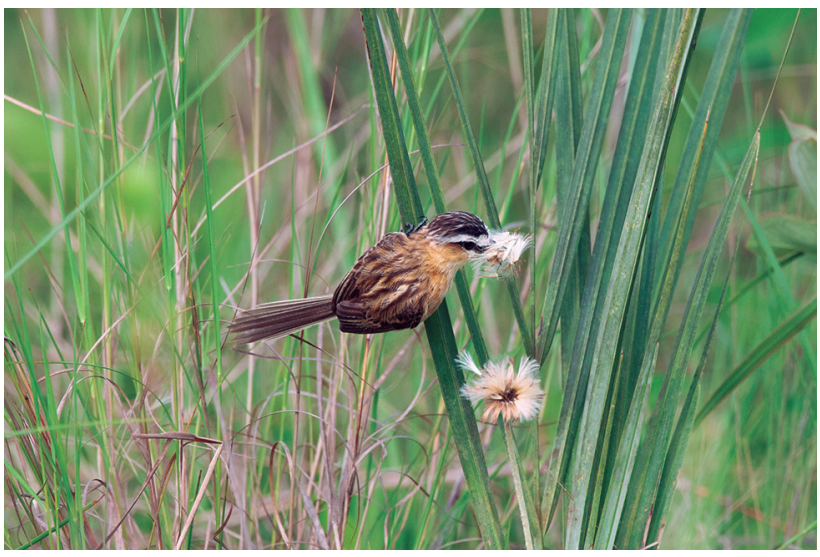

Figure 8. Adult Culicivora caudacuta collecting material for the nest. Photo: RSS. 
height 70, diameter 50, internal depth 40, inner diameter 25-30 (Hartert \& Venturi, 1909).

A more detailed study was carried much later at El Bagual Ecological Reserve (261' S, 58 $\left.56^{\prime} \mathrm{W}\right)$, Formosa province, Argentina, from 1995 to 2010, with more than 500 nests (Di Giacomo, 1996, 2005; Di Giacomo et al., 2011). These were built on annual herbs, the most important ones being Vernonia chamaedrys (Asteraceae) (more than $30 \%$ of the nests), Desmodium cuneatum (Fabaceae) (13\%), Solidago chilensis (Asteraceae) (10\%), and Eupatorium ivaefolium (Asteraceae) (8\%), with additional 10 species accounting for the remainder.

As in our study area, nests were supported by several vertical or nearly vertical branches or, in some cases, inflorescences as in V. cognata, E. eburneum and E. elegans. Average nest height above ground was $1 \mathrm{~m}$, ranging from $0.45 \mathrm{~m}$ to $1.8 \mathrm{~m}$. Most nests were quite visible and similar to each other, built in the shape of compact, wellbuilt half-spheres, straw or yellowish coloured with white inner lining. Nests are built with fine plant matter such as dry fibres, petioles, Poaceae and Asteraceae flowers bound with silk from spider webs or egg sacs. The same material is used to anchor the nest to supporting branches, which varied from three to eight. The nest chamber is lined with very soft material, mostly fine fibres from Asteraceae inflorescences (Di Giacomo, 2005).

Additional nests were found at Brasília National Park ( $\left.15^{\circ} 47^{\prime} \mathrm{S}, 47^{\circ} 56^{\prime} \mathrm{W}\right)$, central Brazil, on 12 November 2004, and two nests were found at Chapada dos Veadeiros National Park $\left(14^{\circ} 05^{\prime} \mathrm{S}, 47^{\circ} 40^{\prime} \mathrm{W}\right)$, Goiás state, in November 2005 and November 2006 (Braz, 2008). The nests were attached to vertical branches and shaped as deep cups. These were built with fine plant material including dried fibres, petioles, grass flowers and leaves woven with spider webs. Height above ground ranged from $64 \mathrm{~cm}$ to $1 \mathrm{~m}$. Measurements of the nest found in November 2006 were inner diameter 20.9, outer diameter 44.4 and depth 54.8 (Braz, 2008).

Another study at Águas Emendadas Ecological Station $\left(15^{\circ} 32^{\prime} \mathrm{S}, 47^{\circ} 36^{\prime} \mathrm{W}, 1,040 \mathrm{~m}\right)$, Distrito Federal, between 2004 and 2007, provided information on three nests. One, with three eggs, was found on 10 November 2005 at $0.34 \mathrm{~m}$ above ground on an Esenbeckia pumila (Rutaceae) bush $0.50 \mathrm{~m}$ tall. The other nests, one found on 22 and the other on 24 November 2007, were about 150 m apart in an open grassland. Both were on Eremanthus glomerulatus (Asteraceae) bushes about $0.55 \mathrm{~m}$ high, built $0.34 \mathrm{~m}$ and $0.53 \mathrm{~m}$ above ground (Sousa \& Marini, 2007). In the same area another nest was found on 4 October 2009 in a campo sujo area built $38 \mathrm{~cm}$ above ground and having three eggs (Marini et al., 2012).

The following additional accounts of nests of C. caudacuta found in Brazil provide more limited but important information as to localities and breeding dates for the species.

A nest found in late October and another in early November 2000 were cup-shaped and built near the ground inside grass clumps at Emas National Park $\left(18^{\circ} 08^{\prime} \mathrm{S}, 52^{\circ} 56^{\prime} \mathrm{W}\right)$, Mineiros municipality, Goiás state (Hass \& Silva e Silva, 2008).
Also at Emas National Park, but at Chapadão do Céu ( $\left.18^{\circ} 17^{\prime} 48^{\prime \prime} \mathrm{S}, 52^{\circ} 46^{\prime} 53^{\prime \prime} \mathrm{W}, 850 \mathrm{~m}\right)$ a nest with three eggs attended by one incubating adult was found on 7 November 2004. The nest had been built $84 \mathrm{~cm}$ above ground on a Vernonia sp. (Asteraceae), in a campo sujo dominated by Tristachya leiostachya (Poaceae), and measured: total height 55, inner depth 30, external diameter 56, inner diameter at the rim 43 (Dante Buzzetti pers. comm. May 2020).

Southeast of Serra de Carrancas $\left(21^{\circ} 27^{\prime} \mathrm{S}, 44^{\circ} 37^{\prime} \mathrm{W}\right.$, ca. 1,250 m), Carrancas, Minas Gerais state, a nest with three eggs was found on 21 October 2008. This was on a Diospyros hispida (Ebenaceae) bush in a small patch of campo sujo by a forest. The nest had been built with grass inflorescences and fine plant fibre (silk cotton), the latter mostly lining the incubation chamber. As other nests, the material was bound by spider webs, resulting in a soft and light, but resistant, construction. Measurements were: depth of the incubation chamber 30, external height 45, inner diameter 30 and external diameter 55 (Lombardi et al., 2010).

On 9 November 2006 a nest with two eggs was found at the headwaters of the Arroio Macena (28 $30^{\prime} 55^{\prime \prime} \mathrm{S}$, $\left.50^{\circ} 47^{\prime} 56^{\prime \prime} \mathrm{W}, 940 \mathrm{~m}\right)$, Vacaria, Rio Grande do Sul. This was described as a delicate cup-shaped structure covered by silk cotton, built on a bush in a small wetland near a fallow dominated by Senecio sp. (Asteraceae) (Rovedder et al., 2007).

One adult was photographed bringing nest material (silk cotton) to its nest at Itirapina Ecological Station ( $\left.22^{\circ} 13^{\prime} \mathrm{S}, 47^{\circ} 54^{\prime} \mathrm{W}, 740 \mathrm{~m}\right)$, Itirapina, São Paulo state, on 27 November 2009. The nest had been built in an isolated bush in open grassland (Motta-Jr. et al., 2020).

Further nests found in different Brazilian localities have been documented with photographs. On 12 November 2019 a nest was found at Barbacena, Minas Gerais state, and on 10 January 2008 a nest with eggs was located at Indianópolis, Minas Gerais. Another was photographed at Piraí do Sul, Paraná state, on 18 January 2014 (WikiAves, 2020).

\section{Eggs, clutch size, incubation}

On 25 October 2005, Nest 3 had three light cream eggs (Fig. 9), measuring $13.31 \times 12.26,13.56 \times 11.75$ and $13.51 \times 11.58$, respectively. The adults were seen taking turns at incubation (Fig. 10), but its length could not be determined.

A nest found at Emas National Park, Goiás, on 7 November 2004 had three light cream eggs measuring $14.3 \times 11.5,14.2 \times 11.3$ e $14.0 \times 11.4$. When revisited on 13 November 2004 it was abandoned (Dante Buzzetti pers. comm. May 2020).

Our small sample precludes generalisations but a clutch size of three and egg colour agree with previous information from Argentina (Hartert \& Venturi, 1909; Di Giacomo, 2005; Di Giacomo et al., 2011), Central Brazil (Sousa \& Marini, 2007; Braz, 2008) and Minas Gerais (Lombardi et al., 2010).

All published information puts egg size range at 14-18.7 $\times 10.3-12.4 \mathrm{~mm}$, the eggs found at CMT being 


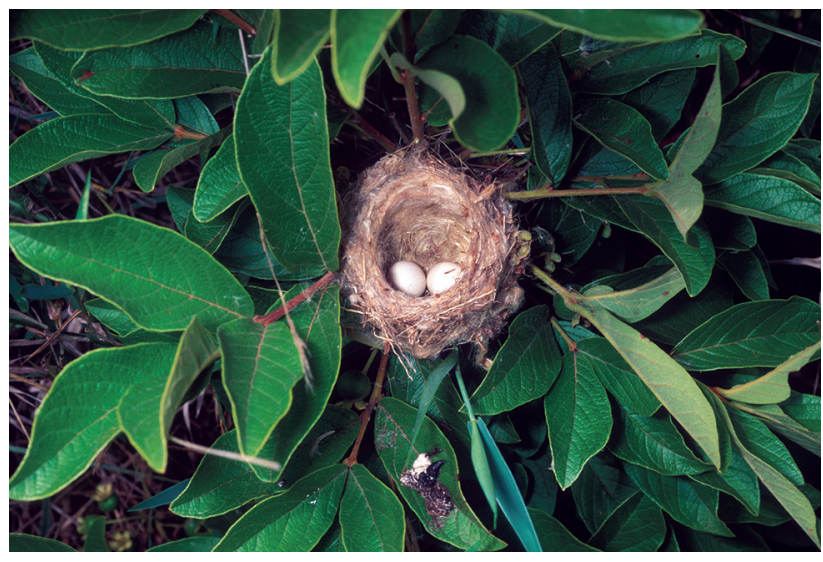

Figure 9. Nest 3 of Culicivora caudacuta with eggs. Photo: RSS.

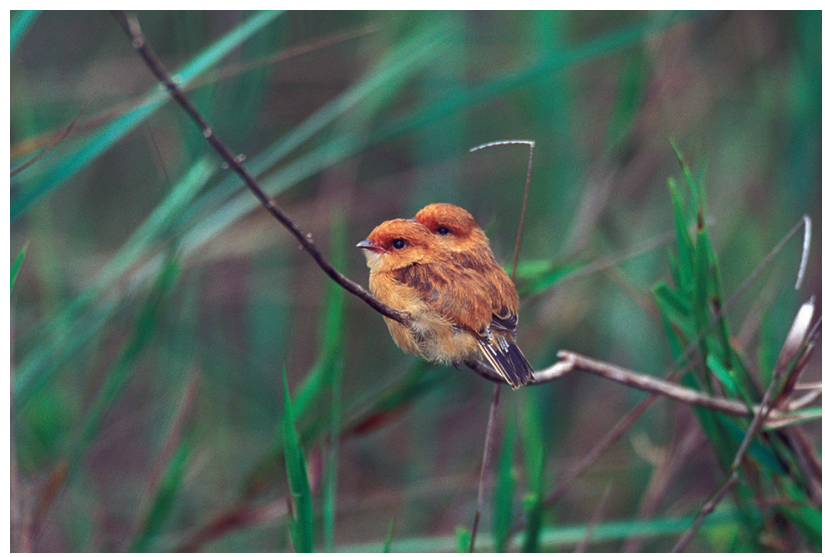

Figure 11. Fledglings of Culicivora caudacuta near Nest 1. Photo: RSS.

unusually short. The significance of this, if any, remains to be assessed.

Di Giacomo (2005) and Di Giacomo et al. (2011) state that incubation begins after the penultimate egg is laid and lasts 15 to 16 days. The pairs may have a second clutch during the same nesting season but this is raised in a newly built nest in a different part of the territory.

\section{Nestlings, juveniles and parental care}

Nest 1 was found on 8 December 2003 when the young had already left and were being attended by the parents. The short-tailed fledglings were orange-brown colour (Fig. 11). They remained in the nearby shrubs and were seen to be fed by three different adults (sometimes at the same time) with dragonflies, horseflies and other flying insects (Figs. 12 and 13) until the 11 December. This family group provided the first published photographs of young C. caudacuta (Silva e Silva, 2004).

Later, on 16-17 January 2004, the young already showed longer tails and foraged by themselves, but always associated with the three adult birds.

On 8 November 2004 Nest 2 had two downy nestlings only a few days old attended by three adults that fed them beetles, dragonflies and flies and removed faecal sacs (Fig. 14), which were dropped $10 \mathrm{~m}$ away from the nest.

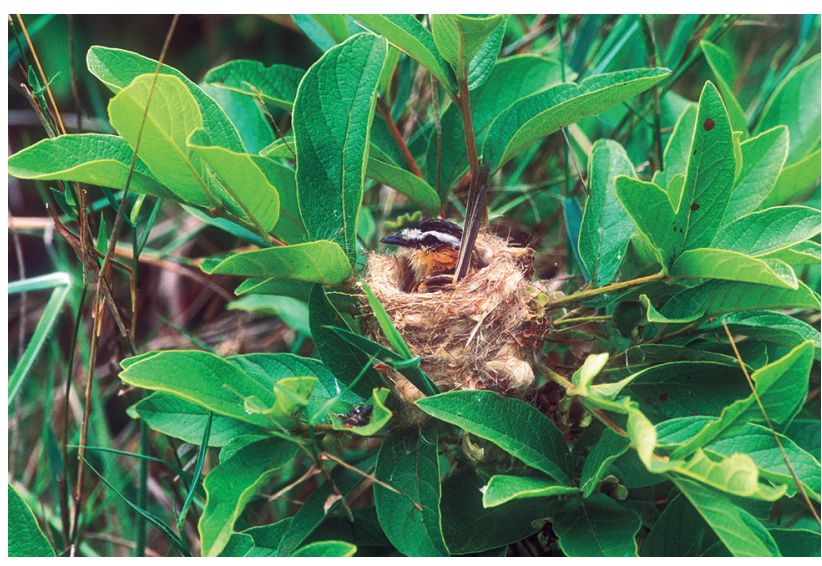

Figure 10. Nest 3 of Culicivora caudacuta, with adult incubating, 250 ctober 2005. Photo: RSS.

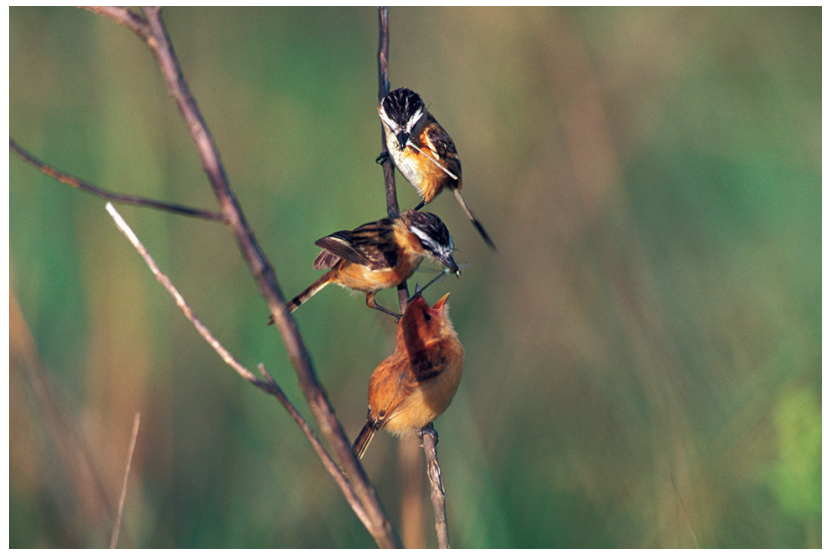

Figure 12. Two adults feeding a nestling with dragonflies, 8 December 2003. Photo: RSS.

On 15 December 2004 the young had already fledged and were foraging by themselves but were still followed by the three adults. A few times two adults were seen to harass the young to direct them back near to the nest.

On 7 and 8 November 2005 Nest 3 had one egg and one nestling (Fig. 15) already covered in orange-cream feathers, lighter on the underparts, and scattered down. It was also attended by three adults that fed it with horseflies, small grasshoppers, flies and dragonflies (Fig. 16) mostly caught 5-10 m from the nest. The nestling would produce a faecal sac soon after being fed and one of the adults would at once take it and drop five meters or so from the nest, closer than seen in the previous nest. The nestling was able to raise itself from the nest but kept still most of the time, calling when it heard the voice or wing sounds of adults nearby.

Nests were not found the following nesting season at CMT but breeding was confirmed on 29 November 2006 when two adults, one previously banded at the site on 2 December 2005, and one short-tailed fledgling were seen. The young bird already showed a long tail and was following the adults when found again on 28 December 2006 and 24 January 2007.

The following day one adult pair followed by two young was found in the same area, with two adults and three young on 7 March 2007. One of these showed a whiter supercilium, a characteristic of an older bird than 


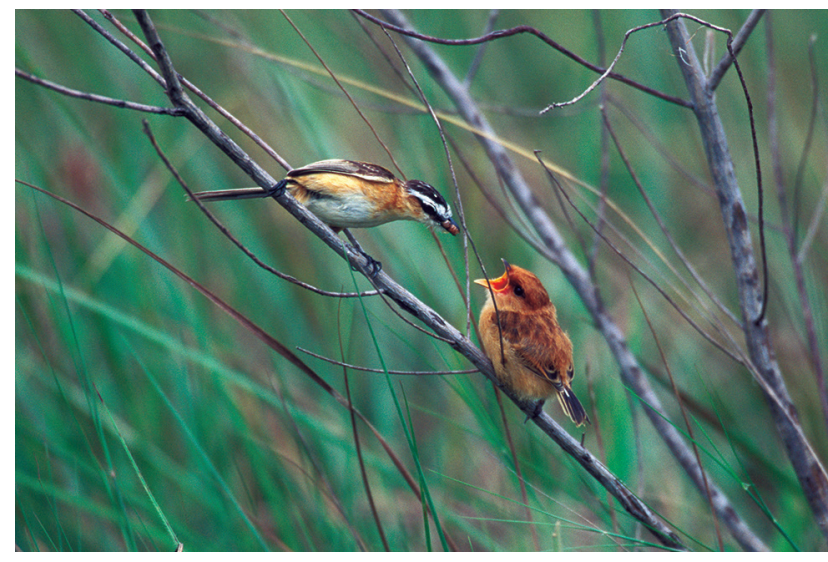

Figure 13. Adult feeding a nestling with a fly, 8 December 2003. Photo: RSS.

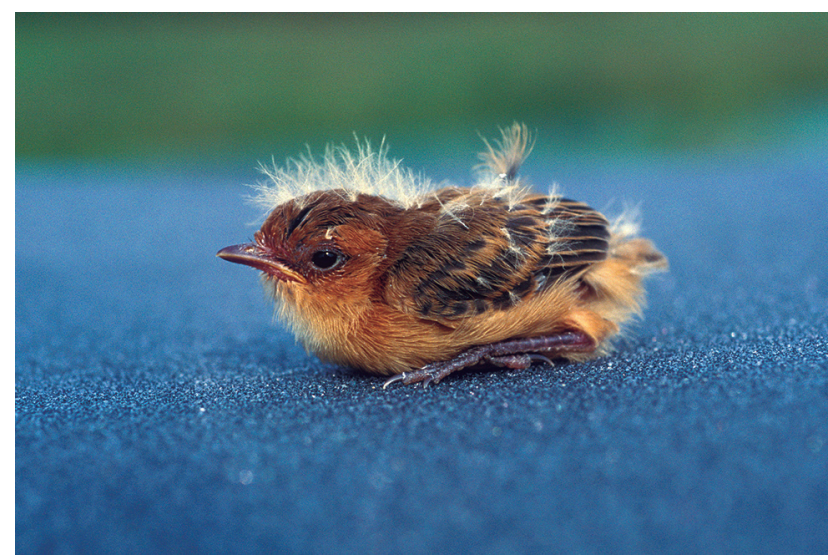

Figure 15. Culicivora caudacuta nestling. Photo: RSS.

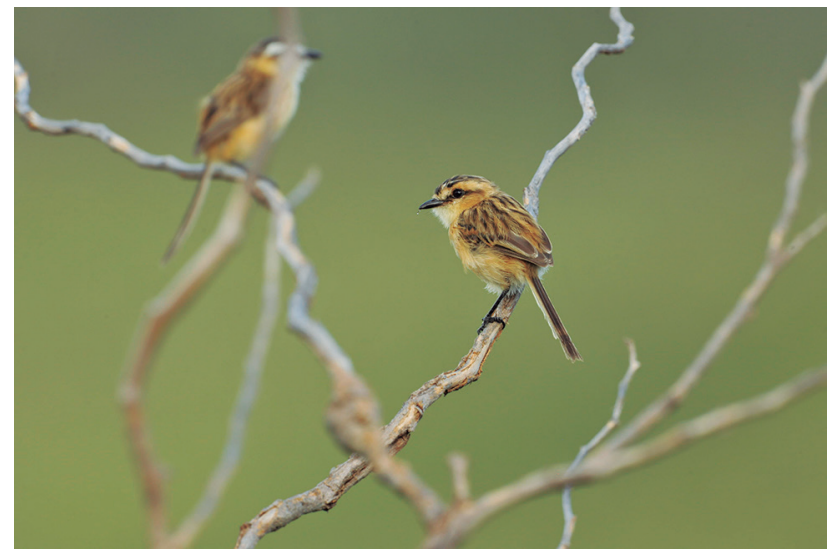

Figure 17. Juvenile Culicivora caudacuta, with adult in the background. Photo: RSS.

its siblings suggesting that the young from two consecutive clutches were following their parents.

Additional information on youngsters was gathered at other sites. At Patrocínio, around the headwaters of Córrego Bebedouro, two adults and one young were found on 6 February 2009, with one adult being captured and banded. Two adults and one young were also seen on 14 and 16 January 2012.

Also at Patrocínio, at the headwaters of Córrego Capoeira Grande, three adults and one young were seen on 1, 6 and 13 March 2011 (Fig. 17). The following sea-

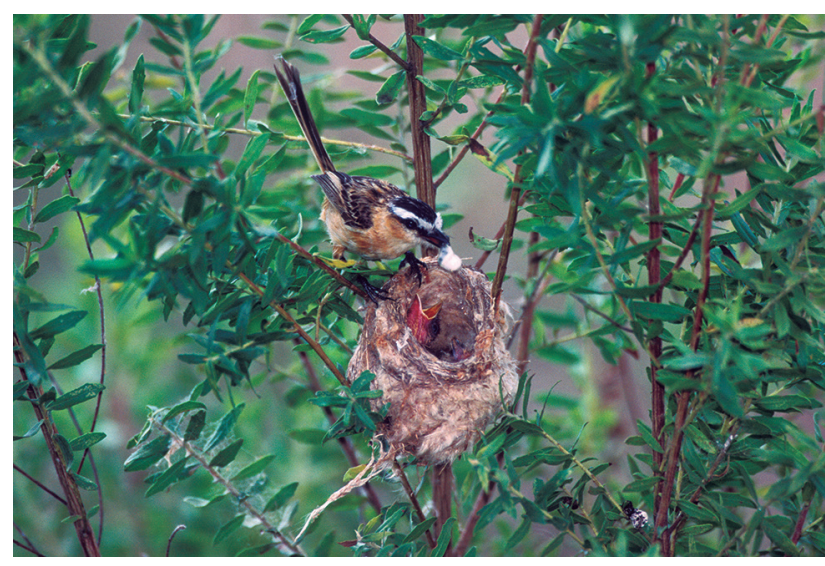

Figure 14. Adult removing a faecal sac from Nest 2 after feeding the nestlings. Photo: RSS.

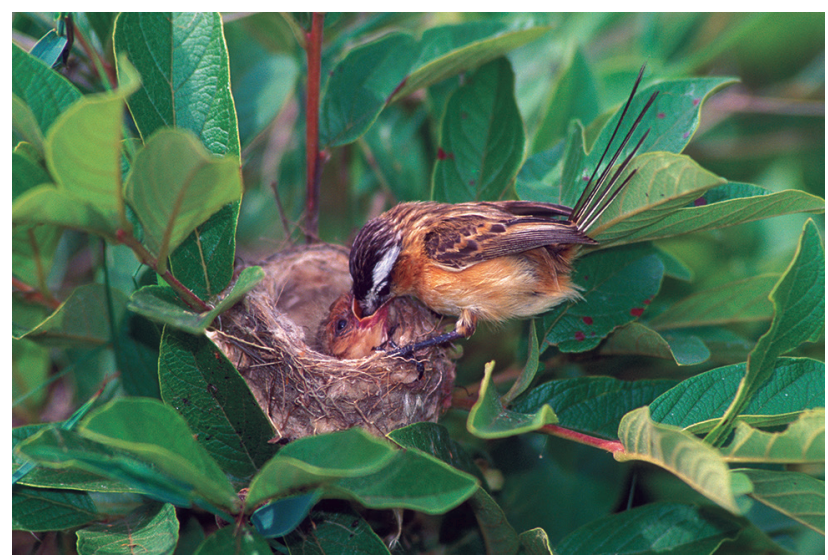

Figure 16. Adult feeding the nestling. Photo: RSS.

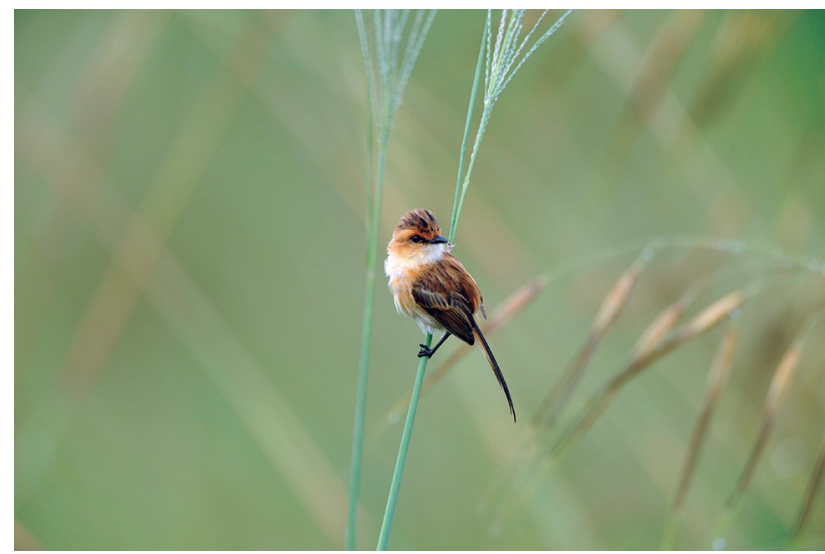

Figure 18. Juvenile of Culicivora caudacuta, Ribeirão Batalha. Photo: RSS.

son, two adults followed by two young were found on 12 January 2012.

At Paracatu, around Ribeirão Batalha, three adults and one young (Fig. 18) were found near a Mauritia palm swamp on 27 January 2009.

The available literature provides further data on the presence of young $C$. caudacuta in other localities, mostly in Brazil. Although most mentions are just brief it is worth listing them in order to add more information.

In Brazil, the first data on young Sharp-tailed Tyrants are from 12 October 1988 at Fazenda Perdões (18¹1'41"S, 
$\left.45^{\circ} 25^{\prime} 17^{\prime \prime} \mathrm{W}, 810-730 \mathrm{~m}\right)$, Três Marias, Minas Gerais. Two adults were seen feeding two juveniles showing a paler colour compared to the adults, lacking the black on the cap (Ribon et al., 1995).

On 17 February 1991 two fledglings were recorded calling at Itirapina Ecological Station (Parker III \& Willis, 1997).

In December 1996, a family group with two dependent young was found at Serra da Canastra National Park $\left(20^{\circ} 15^{\prime} \mathrm{S}, 46^{\circ} 37^{\prime} \mathrm{W}\right)$, São Roque de Minas, Minas Gerais (Silveira, 1998). Adults and three young were seen on 12 February 2002 (Dante Buzetti pers. comm. May 2020), and on 8 February 2006 three adults and one young were seen in the same park (RSS).

At Brasília National Park, a nest was found on 12 November 2004 with three nestlings being fed by two adults. The young had emerging wing, tail and body feathers and an average weight of $4.33 \mathrm{~g}$, but were predated five days later (Braz, 2008).

At Chapada dos Veadeiros National Park a nest was found in November 2006 with two nestlings still showing a mostly naked body, with just some down on the cap, back and wings. These had an average weight of $1.5 \mathrm{~g}$ and were taken by a predator four days later (Braz, 2008).

During a study at Águas Emendadas Ecological Station, two young in different family groups were found in November 2004 and April 2005. They showed completely cinnamon-coloured faces, short tail feathers and limited flight but, two months later, one of them had a full black mask and made several vocalizations (Sousa \& Marini, 2007). In the same area, a nest was found on 4 October 2009. It had three eggs that hatched around 17 October, but the nestlings were preyed on about eight days later (Marini et al., 2012).

At Jalapão, Mateiros, Tocantins state, in a patch of cerrado and campo sujo, bordering a soy plantation $\left(10^{\circ} 27^{\prime} 56^{\prime \prime} \mathrm{S}, 46^{\circ} 08^{\prime} 34^{\prime \prime} \mathrm{W}, 770 \mathrm{~m}\right)$, five birds, including a recently fledged young bird, were seen on 24 March 2018 (Dornas \& Pascoal, 2019).

At Carrancas, Minas Gerais, young were found in May 2009 and January 2010, and in the same region, at Serra da Chapada das Perdizes (1,500 m), on the border of Minduri municipality, further young were recorded in January 2010 (Lombardi et al., 2012).

On 7 October 2005, at Fazenda Indiana $\left(20^{\circ} 25^{\prime} \mathrm{S}\right.$, $\left.56^{\circ} 39^{\prime} \mathrm{W}, 120 \mathrm{~m}\right)$, Rio Salobra, Bodoquena, Mato Grosso do Sul, two adults with two young were observed in a recently burnt fallow near a rice plantation (Pivatto et al., 2006).

At Fazenda Pai João $\left(28^{\circ} 10^{\prime} 58^{\prime \prime} \mathrm{S}, 50^{\circ} 38^{\prime} 28^{\prime \prime} \mathrm{W}\right.$, $1,005 \mathrm{~m})$, Capão Alto, Santa Catarina, one pair of adults followed by a juvenile was found on 13 January 2013 in a grassy area with sparse flowering bushes (RSS). At the same locality, on 22 January 2012, one young and one adult were photographed together, while on 30 January 2012 , one young was photographed (Wikiaves, 2020).

The nest found with two eggs at Vacaria, Rio Grande do Sul, on 9 November 2006 (Rovedder et al., 2007) was photographed on 20 November 2006 with one nestling (Repenning et al., 2010).
Near lbirapuitã Biological Reserve, at Fazenda do Beto, Alegrete, Rio Grande do Sul, four individuals, including young, were found in early February 2001 (Fontana et al., 2003).

In Paraguay, on 13 February 1995, at Aguara Nu, Bosque Mbaracayú Natural Reserve $\left(24^{\circ} 09^{\prime} \mathrm{S}, 55^{\circ} 17^{\prime} \mathrm{W}\right)$, Canindeyu departament, one adult and one immature were seen (Madroño Nieto \& Esquivel, 1997).

Also in Paraguay, at Estancia Kanguery $\left(26^{\circ} 30^{\prime} \mathrm{S}\right.$, $\left.55^{\circ} 47^{\prime} \mathrm{W}\right)$, Itapúa department, San Rafael National Park, three recently fledged juveniles were seen, and photographed together with two adults on 5 April 2016 (Smith, 2017).

In Argentina, at Estancia Virocay ( $\left.28^{\circ} 15^{\prime} \mathrm{S}, 55^{\circ} 57^{\prime} \mathrm{W}\right)$, Corrientes, two young following a pair of adults were found on 16 December 2010 (Marino et al., 2013).

The young acquire full adult plumage five to six months after fledging and juvenile-plumaged birds were not recorded during the cold and dry winter months.

The juvenile plumage of $C$. caudacuta remained undescribed for a long time despite at least two juveniles having been collected by Johann Natterer in the early $19^{\text {th }}$ century. Among the eleven $C$. caudacuta collected by Natterer in Brazil, including nine from São Paulo and two from Paraná (Pelzeln, 1868-1870), two specimens, NMW 17822 and NHMUK 1888.1.13.331 (Fig. 19), both collected on 11 February 1821 at Itararé, São Paulo state, are juvenile. The specimens are held at the collections of the Naturhistorisches Museum Wien (NMW), at Vienna, Austria (Hans Berg-Martin in litt., 2020), and Natural History Museum, Tring, UK (Hein van Grow in litt., 2021).

Another specimen (ZSM 32700), which had probably just fledged judging from its short tail and colour, was collected in Paraguay on 4 December 1931 and is housed in the ornithological collections of the Zoologische Staatssammlung München (ZSM), Munich, Germany (Fig. 20), remained unknown until now (Markus Unsöld in litt., 2020). This is one of four specimens of $C$. caudacuta collected in Paraguay during the 1931 expedition (Laubmann, 1940).

Despite this, the juvenile plumage of C. caudacuta was first shown in a field guide by Sigrist $(2004,2007)$, based on photographs taken at CMT by RSS.

As described in this guide, the juvenile plumage of C. caudacuta, from the time they fledge until acquiring adult plumage, is quite distinctive and unlikely to be confused with the non-breeding plumage or female of the Bearded Tachuri Polystictus pectoralis, as shown by Smith (2017).

The female and young male of $P$. pectoralis show most of the head blackish, contrary to C. caudacuta which, after fledging and while still showing a short tail, has practically no black on the head.

As the tail grows and becomes as long as the head and body, the young start showing the first black streaks on the cap and show a very different jizz from the short, broad-tailed $P$. pectoralis.

Of 1,698 photos of C. caudacuta available at Wikiaves (2020), up to 16 May 2020, only 47 show juvenile birds. These were taken at Tocantins, Goiás, Distrito Federal, Bahia, Minas Gerais, Paraná, Santa Catarina and Rio Grande do Sul, showing the confirmed breeding range 


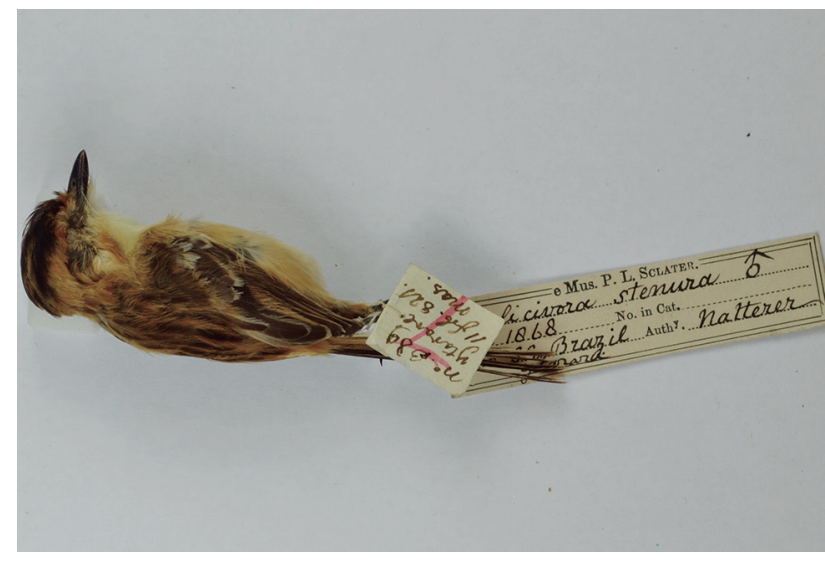

Figure 19. Immature specimen of Culicivora caudacuta at Natural History Museum, Tring. Photo: Hein van Grow.

includes most of the species' range in Brazil. The presence of young in the months of October, November, December, January, February, March, April, and May agrees with the observations in the literature and the ones presented above, and suggest more than one brood can be raised per season.

\section{Cooperative breeding and helpers}

A common feature of family groups of $C$. caudacuta was the presence of three adult birds sharing the duties of incubation and provisioning of the young (Silva e Silva, 2006).

When Nest 1 and its fledglings were found in December 2003, three adults were found caring for the two young that remained next to the nest. Even when the young were already foraging by themselves, on 16 January 2004 and 2 February 2004, the three adults stayed near them, forming a family group, but only two of the adults would react aggressively to playback.

At Nest 2, found with two nestlings, three adults took turns feeding them and removing faecal sacs. The young continued to be attended by the three adults after they left the nest but, again, only two of the adult birds would approach in response to playback, the third remaining some distance away uttering softer and lower calls. Nest 3 also had three adults attending its single young from incubation until well after it had fledged.

The same behavior was also recorded in other sites we visited in Minas Gerais. At Ribeirão Batalha, Paracatu, one young bird attended by three adults was recorded on 9 November 2005 and 27 January 2009. The same grouping was seen on 1, 6 and 13 March 2011 at Patrocínio, near Córrego Capoeira Grande, when three adults and one young bird were attracted with playback.

The same grouping was found during a study on C. caudacuta at Águas Emendadas Ecological Station, where one young bird was attended by three adults, one of these providing food with higher frequency (Sousa \& Marini, 2007).

Cockburn (2006) states that among the 1,097 New World suboscines, cooperative breeding is consistently rare, found in just $1 \%$ of the species. By contrast, a sig-

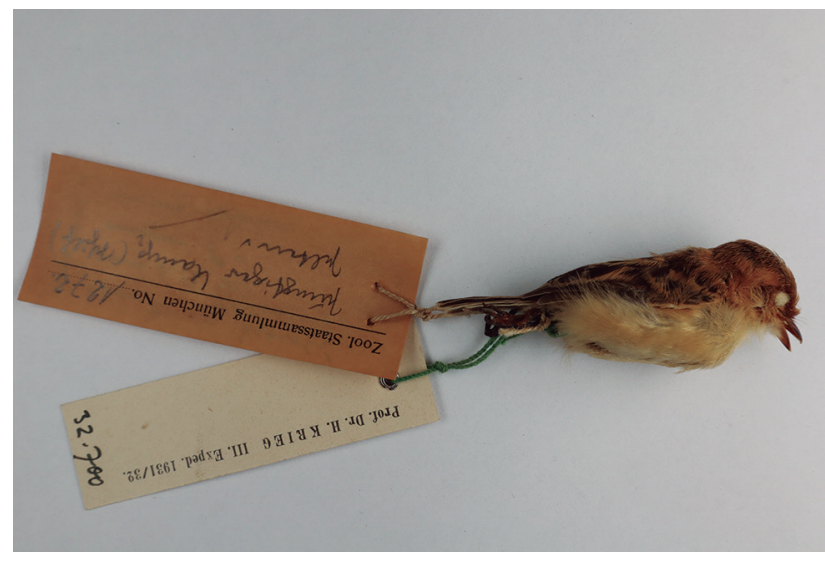

Figure 20. Specimen of young Culicivora caudacuta at Zoologische Staatssammlung München. Photo: Markus Unsöld.

nificantly larger proportion of all oscines are cooperative breeders (13\%).

Although Fitzpatrick (2004) states no tyrant flycatcher is known to exhibit cooperative breeding on a regular basis, Griesser \& Suzuki (2016) show that among the Tyrannidae, six species show cooperative breeding.

According to Griesser \& Suzuki, (2016), most (93\%) helpers are offspring that remain associated with their parents until the next breeding season and provide alloparental care at the nest of their parents or close relatives.

Following this pattern, it is likely the helpers among C. caudacuta are young from the previous nesting season that remained in the natal territory through the following season.

During the fieldwork recently carried out in Patrocínio, Minas Gerais, in August 2020, three groups of three individuals each of $C$. caudacuta were found, where it was noted that only two of these individuals responded promptly to playback, while the third individual was more distant and responded with a much softer and weaker vocalization, being possibly a young bird accompanying its parents.

Detailed studies, including genetic profiling, are necessary to further knowlege on this behavior in C. caudacuta and the few tyrant flycatchers also showing helper behavior like Streamer-tailed Tyrant Gubernetes yetapa (Wagener et al., 2019).

\section{Birds' measurements}

Eleven birds were captured for ringing in the study sites: nine, including one young, at Tapira between 1 and 2 December 2005, one at Paracatu on 28 December 2005, and another at Patrocínio on 6 February 2009. The measurements are in Table 1. These fall in the range of the 13 birds captured at Águas Emendadas Ecological Station (Sousa \& Marini, 2007).

\section{Distribution}

The first information on the distribution of C. caudacuta was supplied in the $18^{\text {th }}$ century by Félix de 
Table 1. Measurements $(\mathrm{mm})$ and body mass $(\mathrm{g})$ of Culicivora caudacuta from Tapira $(n=9)$, Paracatu $(n=1)$ and Patrocínio $(n=1)$.

\begin{tabular}{lccccccccccccccc}
\hline \multirow{2}{*}{ Age } & \multicolumn{3}{c}{ Bill } & \multicolumn{4}{c}{ Tail } & \multicolumn{3}{c}{ Wing } & \multicolumn{3}{c}{ Tarsus } \\
\cline { 2 - 13 } & Min. & Mean & Max. & Min. & Mean & Max. & Min. & Mean & Max. & Min. & Mean & Max. & Min. & Mean & Max. \\
\hline Adult & 7.05 & 7.61 & 8.17 & 42.94 & 47.77 & 52.54 & 36.63 & 38.65 & 39.63 & 12.56 & 14.15 & 15.82 & 6 & 6.2 & 7.5 \\
Juvenile & & 5.77 & & & 40.15 & & & 37.15 & & & 12.81 & \\
\hline
\end{tabular}

Azara and mentioned in the species' description, where Paraguay was assumed as the type locality (Vieillot, 1818). Nevertheless, Azara's observations also covered nearby parts of Argentina and Brazil (Beddall, 1975) where C. caudacuta is known to occur, the presence of the species in Brazil having already been noted in the early $19^{\text {th }}$ century (Temminck, 1822). The assignment of Paraguay as type locality is accordingly best seen as tentative.

It took much longer for the actual distribution of C. caudacuta to be better understood as including parts of Brazil, Bolivia, Paraguay, and Argentina (Lopes et al., 2009). However, coverage was limited and the gaps that were shown may not be real.

Technological progress, especially the greater availability of digital cameras and sound recorders, with the rise of birdwatching and on-line platforms for ornithological data, such as Wikiaves, xeno-canto and eBird has increased coverage in a dramatic way and resulted in a jump in the known localities for the species.

On the other hand, greater coverage and the resulting increase in the number of localities mean that caution is required in considering claims that $C$. caudacuta may be expanding its range.

The recent data show that the area of occupancy of $C$. caudacuta has been underestimated. Using Minas Gerais state $(58,652,800 \mathrm{ha})$, in Brazil, as an example, the species was previously known from just three localities (Lins, 1998), later jumping to 20 (Lopes et al., 2009), and with the compilation presented here this jumps to 134 localities (Appendix 1; Fig. 21).

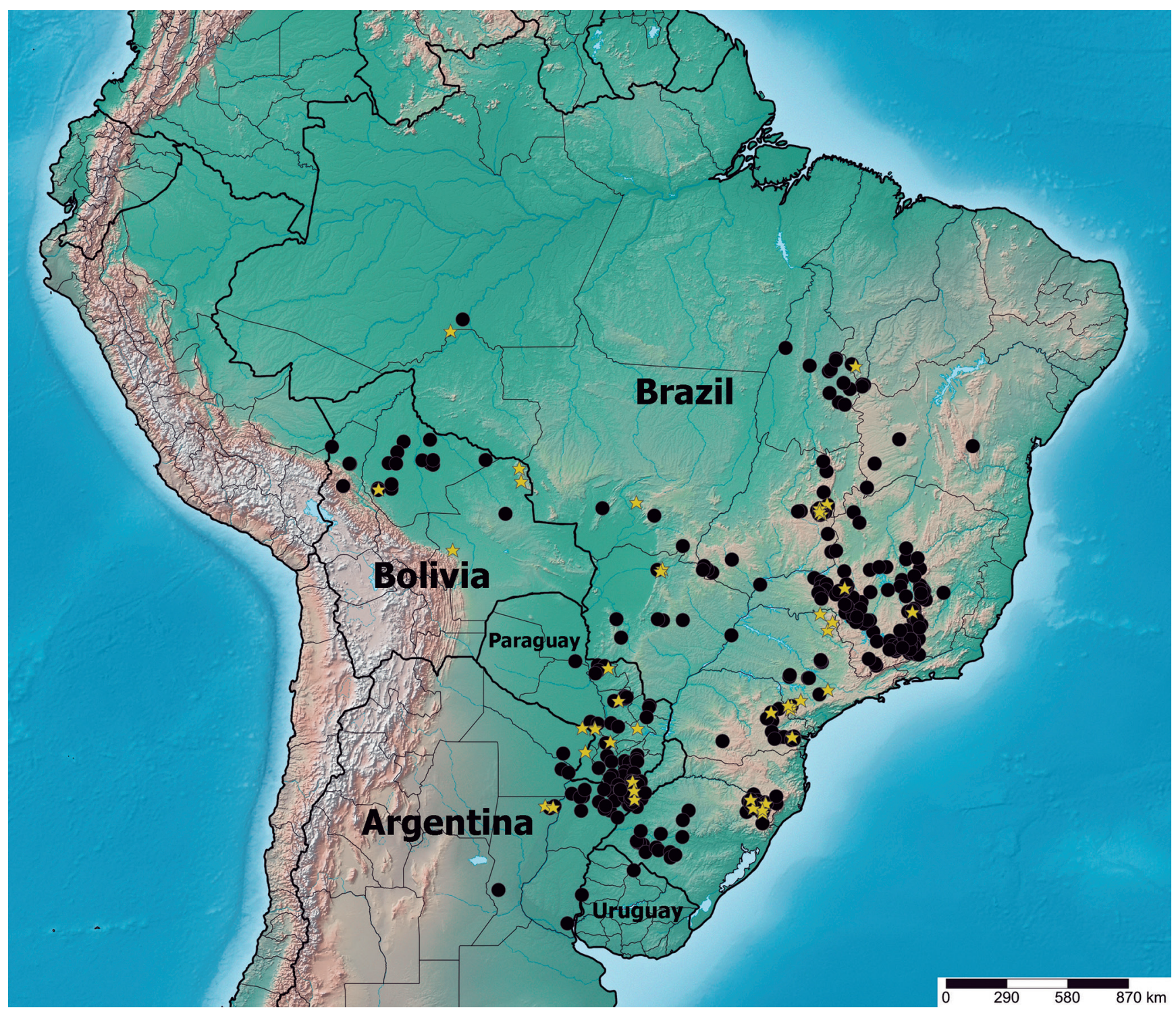

Figure 21. Records of Culicivora caudacuta. Yellow stars indicate museum specimens, dots indicate other categories of records. See Appendix 1 for details. 
Culicivora caudacuta is mostly associated with open grassland and savanna of the Pampa and Cerrado biomes characterized by a dense ground cover of grasses and scattered, well-spaced low bushes, occasionally near watercourses, but it also occurs in areas where the original vegetation has already been contaminated by exotic grasses.

Records show it occurs from elevations of $60 \mathrm{~m}$ in the Chaco of Argentina and Paraguay to 1,550 m at Serra da Chapada das Perdizes, in Brazil (Lombardi et al., 2012).

The species has most of its range in Brazil, occurring in all major regions. Its presence in the states of Amazonas, Tocantins, Bahia, Santa Catarina and Rio Grande do Sul was confirmed only in the past two decades, showing the imperfect knowledge on its distribution. Regarding the last two states, Fontana et al. (2008) point out that the lack of previous records is best considered a result of a lack of studies rather than a colonization event.

Among the new localities where the species has been found are savanna enclaves in the region of Humaitá and Canutama (MZUSP; Wikiaves, 2020), in southern Amazonia (now being converted for soybean crops), and similar habitats at Campos Amazônicos National Park $(961,317.77 \mathrm{ha})$ further east, where other grassland specialists have also been found (Cândido-Jr. \& Dal'Maso, 2016). The Amazonian savannas are of great ecological interest and, in the case of the national park, may protect significant populations of the species.

The species has also been cited as occurring in Amapá state (BirdLife International, 2020b), another Amazonian region with extensive savannas, but the source of this record could not be traced and this locality was excluded here.

The current information shows that $C$. caudacuta has a much broader range than first thought, and besides at least 13 Brazilian states where it has been found, in Bolivia, in the departments of El Beni, La Paz and Santa Cruz; in Paraguay in the departments San Pedro, Presidente Hayes, Cordillera, Paraguarí, Concepción, Canindeyú, Caaguazú, Caazapá, Itapúa and Misiones; in Argentina in the provinces of Misiones, Chaco, Corrientes, Entre Ríos, Formosa and Santa Fe; and In Uruguay it is known from a single record from the department of Rivera.

Its presence is probable but still undocumented in southeast Peru, at Madre de Dios in the Pampas de Heath $\left(12^{\circ} 53^{\prime} \mathrm{S}, 68^{\circ} 54^{\prime} \mathrm{W}\right)$, a seasonally flooded grassland on the Peru-Bolivia border making a northwestern extension of the Gran Chaco Boliviano-Paraguayo, where several grassland specialists such as Rhynchotus rufescens, Micropygia schomburgkii, Ammodramus humeralis, Sporophila plumbea and Coryphaspiza melanotis have been found (Graham et al., 1980). A record of C. caudacuta from Pampa Moscoso was made just $13 \mathrm{~km}$ from Pampas de Heath, adding to the likelihood of the species occurring there.

\section{Conservation}

Culicivora caudacuta has long figured in threatened species lists: at global level it was considered as

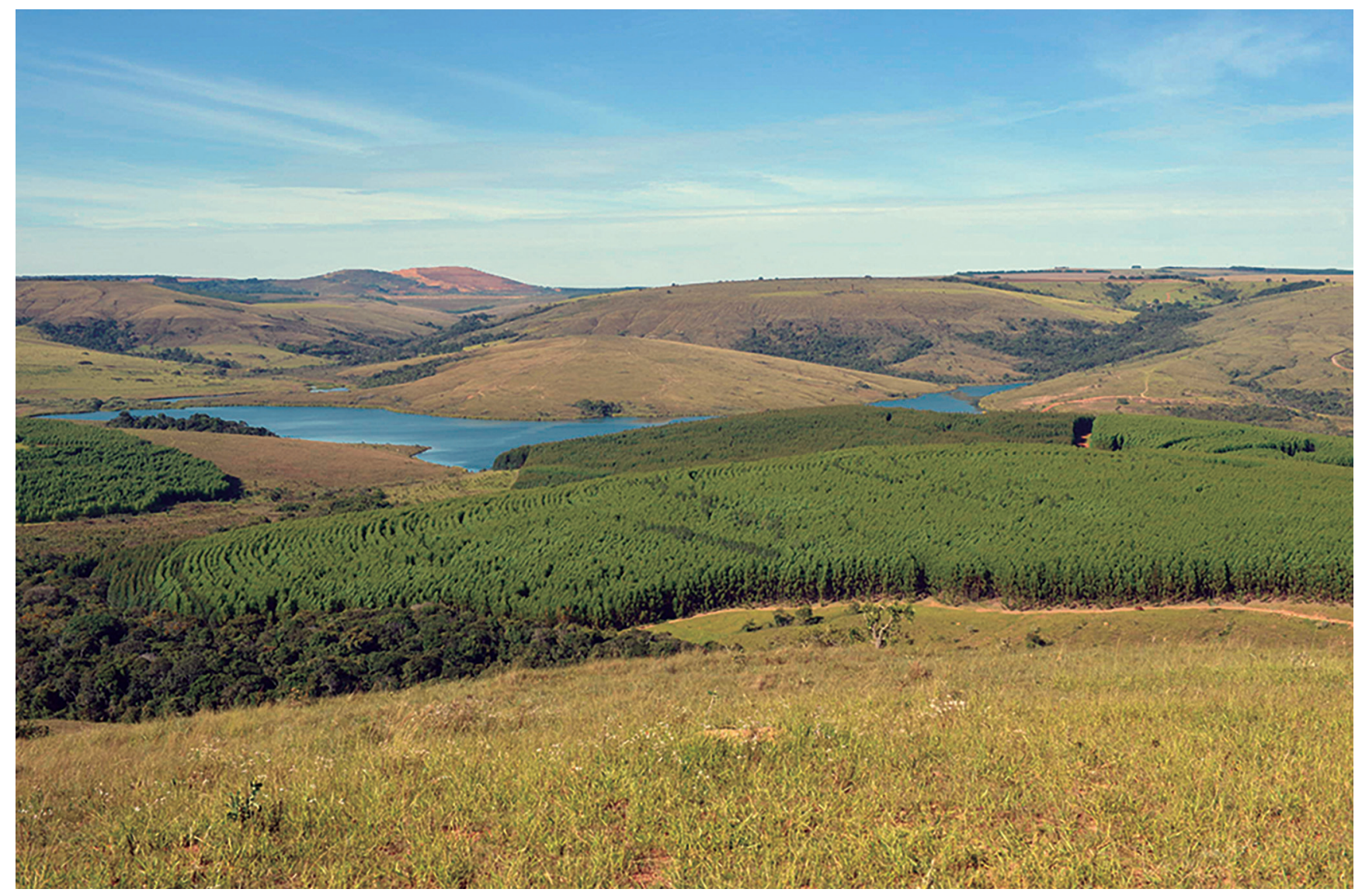

Figure 22. Culicivora caudacuta habitat occupation by Eucalyptus sp. monoculture, Araxá, Ribeirão do Inferno (07 May 2014). Photo: RSS. 
Threatened in 1988, Lower Risk/Near Threatened in 1994 and 2000, and Vulnerable from 2004 to the present (BirdLife International, 2020b).

Most countries in its range consider it to be threatened, as Argentina, where it was considered as Vulnerable (Fraga, 1996), and now as Threatened (Ministerio de Ambiente y Desarrollo Sustentable \& Aves Argentina, 2017).

In Brazil, C. caudacuta is included in several state lists of threatened species, as in Minas Gerais (Lins, 1998; COPAM, 2010), São Paulo (Bressan et al., 2009), Paraná (Mikich \& Bérnils, 2004), Santa Catarina (Occhialini, 2010) and Rio Grande do Sul (Fontana et al., 2003).

On the other hand it has been dropped from the national list since 2014 (ICMBio, 2018), where it was previously listed as Vulnerable (Hass \& Silva e Silva, 2008).

In Uruguay, where it is known from a single locality, it is considered as Vulnerable (Azpiroz et al., 2012), while in Bolivia it is not included in red lists (Balderrama, 2009).

The main reason for $C$. caudacuta to be considered threatened is the widespread conversion of native grasslands all over South America into cultivation, mostly for soybeans, and pastures dominated by exotic grasses where the birds cannot persist (Codesido \& Fraga, 2009; BirdLife International, 2020b).

In the study area the expansion of Eucalyptus monocultures for pulp and charcoal over the natural grasslands continues unchecked and is the main driver of habitat loss (Fig. 22), a trend also in southern Brazil, Uruguay and Argentina also (Modernel et al., 2016).

There are little data on population densities, and all come from Brazil. At Chapada dos Veadeiros National Park the estimated population is $1,475-4,022$ individuals, with an average of 2,433 individuals, while at Brasília National Park there are estimated to be 440 to 2,374 individuals, with an average of 1,021 (Braz, 2008). Kanegae (2011) found densities of 9.6 individuals $/ \mathrm{km}^{2}$ at Itirapina Ecological Station, with a total estimated population of 112 individuals.

Another population has recently been found in Tocantins state, in the Jalapão region including the Serra Geral do Tocantins Ecological Station and Jalapão State Park where a significant population seems to occur (Dornas \& Crozariol, 2012; Dornas \& Pascoal, 2019), especially along the wet grasslands bordering the Mauritia palm swamps veredas.

Culicivora caudacuta has been confirmed to occur at the following state-run protected areas in Brazil: Serra Geral do Tocantins Ecological Station, Jalapão State Park, Chapada Diamantina National Park, RESEX Recanto das Araras de Terra Ronca, Chapada dos Veadeiros National Park, Serra dos Pirineus State Park, Emas National Park, Águas Emendadas Ecological Station, APA Cafuringa, ARIE Cruls, Brasília National Park, Brasília National Forest, Brasília Botanical Garden, Guará Ecological Park, IBGE Ecological Reserve, Serra das Araras Ecological Station, Serra da Boa Esperança State Park, Serra do Cabral State Park, Tabuleiro Municipal Natural Park, Quedas do Rio Bonito Ecological Park, Serra do Intendente State Park, Sempre Vivas National Park, Mata do Limoeiro State Park,
APA Morro da Pedreira, Serra do Rola Moça State Park, Serra do Cipó National Park, Serra da Canastra National Park, São Miguel Wildlife Sanctuary, Santa Bárbara do Rio Pardo Experimental Farm, Santa Bárbara Ecological Station, Itirapina Ecological Station, Botucatu State Forest, Itararé Unit of Research and Development, Vila Velha State Park, Guartelá State Park, APA Rio Iraí, APA Ibirapuitã, Ibirapuitã Biological Reserve, and the following private reserves (as recognised by Brazil's environmental agencies): RPPN Fazenda Minnehaha, RPPN Lagoa do Formoso, RPPN Reserva Natural Serra do Tombador, RPPN SESC Pantanal e Entorno, RPPN Cisalpina, RPPN Fazenda da Barra, RPPN Aves Gerais, RPPN Mata do Jambreiro, RPPN Unidade de Conservação de Galheiros, RPPN Vale Encantado, and RPPN Foz do Rio Aguapeí.

In Bolivia it occurs at Madidi National Park, Barba Azul Nature Reserve, Beni Biological Station, and Noel Kempff Mercado National Park.

Protected areas in Paraguay where C. caudacuta has been recorded are Serranía San Luis National Park, Bosque Mbaracayú Natural Reserve, Kanguery Biological Station, and San Rafael National Park.

In Argentina it occurs in the following protected areas, many private: Puerto San Juan Private Reserve, Campo San Juan Reserve, Urutaú Reserve, Don Lorenzo Refuge, Santa Rosa Private Reserve, Iberá Provincial Reserve, Iberá National Park, Isla Apipé Grande Provincial Natural Reserve, Rincón de Santa María Natural Reserve, Mburucuyá National Park, El Bagual Reserve, Río Pilcomayo National Park, and Federico Wildermuth Provincial Reserve for Multiple Uses.

In Brazil it is likely that C. caudacuta will be found in additional protected areas since about half of the existing ones do not have a management plan with information on their avifauna while others have only preliminary data.

\section{ACKNOWLEDGMENTS}

Most information on the breeding biology of Culicivora caudacuta in Minas Gerais was gathered during bird surveys and monitoring in the properties of Fosfertil (currently Mosaic Fertilizantes), at Uberaba, Tapira, Patos de Minas, Patrocínio and Catalão, this last locality in Goiás. From 2001 to 2012 Fosfertil funded and supported my research and its publicising. My thanks to Paulo Eduardo Batista, communications sector, to the managers of each area, and those who assisted me in fieldwork: Romes do Nascimento, William Caixeta, Wilson Alves Barbosa Filho, Lucio dos Reis Oliveira, and especially, Caroline Favaro Oliveira Valera. Dr. Aristônio M. Teles (Universidade Federal de Goiás) identified the Asteraceae holding nests of Culicivora caudacuta at Tapira. Hans-Martin Berg (NMW), Marco Aurélio Crozariol (MNRJ), Hein van Grow (NHMUK), Eduardo Carrano (MHNCl), Markus Unsöld (ZSM), Luis Fábio Silveira (MZUSP), Maria de Fátima Cunha Lima and Lincoln Carneiro (MPEG), Leonardo Lima Bergamini (IBGE), Steven W. Cardiff (LSUMZ), Sylke Frahnert (ZMB), and Kathia Rivero (MNK), provided information on specimens held at their collections. Markus 
Unsöld, Hein van Grow, Hans-Martin Berg and Eduardo Carrano also kindly provided photographs of the specimens. Dante Buzzetti kindly supplied unpublished data on nests of Culicivora caudacuta. José Fernando Pacheco and Juvêncio Nunes da Costa shared information on localities. Fábio Olmos provided fundamental support for the English version of the manuscript and numerous suggestions and corrections, and Jeremy Minns revised the final English version of the manuscript.

\section{REFERENCES}

Altmann, J. 1974. Observational study of behavior: sampling methods. Behaviour, 49(3-4): 227-267.

Anjos, L. \& Graf, V. 1993. Riqueza de aves da Fazenda Santa Rita, região dos Campos Gerais, Palmeira, Paraná, Brasil. Revista Brasileira de Zoologia, 10(4): 673-693.

Antas, P.T.Z. 1995. Aves do Parque Nacional de Brasília. Brasília, IBAMA.

Antas, P.T.Z.; Cândido-Jr., J.F.; Reinert, B.L.; Pinheiro, R.T. 1993. Lista das aves da Fazenda Jatobá, Correntina, BA. Pp. 29. In: Congresso Brasileiro de Ornitologia, $2^{\circ}$. Resumos. Pelotas, Editora da Universidade Católica de Pelotas.

Antonelli-Filho, R. (Ed.). 2011. Plano de manejo da Reserva Natural Serra do Tombador, Cavalcante, Goiás. Curitiba, Fundação Grupo Boticário de Proteção à Natureza.

Azpiroz, A.B. 1998. Avifauna del Valle del Lunarejo, Rivera. Achará, 1:22-25.

Azpiroz, A.B.; Alfaro, M. \& Jiménez, S. 2012. Lista roja de las aves del Uruguay. Una evaluación del estado de conservación de la avifauna nacional con base em los criterios de la Unión Internacional para la Conservación de la Naturaleza. Montevideo, Dirección de Medio Ambiente.

Bagno, M.A.; Abreu, T.L.S. \& Braz, V.S. 2006. A avifauna da Área de Proteção Ambiental de Cafuringa. In: Neto, P.B.; Mecenas, V.V. \& Cardoso, E.S. (Eds.). APA de Cafuringa: a última fronteira natural do DF. Brasília, Secretaria de Meio Ambiente e Recursos Hídricos do Distrito Federal. Pp. 249-253; 492-501.

Balderrama, J.A. 2009. Aves. Pp. 305-417. In: Aguirre, L.F. (Ed.). Libro rojo de la fauna silvestre de vertebrados de Bolivia. La Paz, Ministerio de Medio Ambiente.

Barnett, J.M.; Klavins, J.; del Castillo, H.; Coconier, E. \& Clay, R. 2004. Nothura minor (Tinamidae) a globally threatened cerrado species new to Paraguay. Ararajuba, 12(2): 153-155.

Bates, J. \& Parker III, T.A. 1998. The avifauna of Parque Nacional Noel Kempff Mercado and surrounding areas. In: Mittermeier, R.A. \& Thomsen, J.B. (Eds.). A biological assessment of Parque Nacional Noel Kempff Mercado, Bolivia. Washington, Conservation International. Pp. 317-340. (RAP Working Papers 10).

Beddall, B.G. 1975. "Un Naturalista Original”: Don Félix de Azara, 1746-1821. Journal of the History of Biology, 8(1): 15-66.

Bencke, G.A. 2001. Lista de referência das aves do Rio Grande do Sul. Porto Alegre, Fundação Zoobotânica do Rio Grande do Sul. (Publicações Avulsas FZB № 10)

Bertoni, A. deW. 1930. Sobre ornitología del Chaco Paraguayo. Aves colectadas por Félix Posner en la Colonia "Monte Sociedad", hoy Benjamin Aceval (Villa Hayes). Revista de la Sociedad Científica del Paraguay, 2(6):241-257.

BirdLife International. 2020a. Important Bird Areas factsheet: Reserva Particular do Patrimônio Natural SESC Pantanal e Entorno. Available: http://www.birdlife.org. Access: 19/06/2020.

BirdLife International. 2020b. Species factsheet: Culicivora caudacuta. Available: http://www.birdlife.org. Access: 19/06/2020.
Bonzi, V.R.; Cabral, H.; del Castillo, H.; Benítez-Riveros, C.; Galluppi, T.; Sforza, L.; Báez, M. \& Yanosky, A. 2020. An assessment of the Important Bird Areas (IBAs) of southern Paraguay grasslands. Bird Conservation International, 1-14.

Brace, R.C.; Hornbuckle, J. \& Pearce-Higgins, J.W. 1997. The avifauna of the Beni Biological Station, Bolivia. Bird Conservation International, 7: 117-159.

Braz, V.S. 2008. Ecologia e conservação das aves campestres do bioma cerrado. PhD Thesis, Departamento de Ecologia do Instituto de Ciências Biológicas, Universidade de Brasília, 178p.

Braz, V.S. \& Cavalcanti, R.B. 2001. A representatividade de áreas protegidas do Distrito Federal na conservação da avifauna do Cerrado. Ararajuba, 9(1): 61-69.

Bressan, P.M.; Kierulff, M.C.M. \& Sugieda, A.M. (Eds.). 2009. Fauna ameaçada de extinção no estado de São Paulo: vertebrados. São Paulo, Secretaria do Meio Ambiente.

Cândido-Jr., J.F. \& Dal'Maso, A. 2016. Avifauna. In: Plano de Manejo Parque Nacional dos Campos Amazônicos. Brasília, ARPA. Pp. 204-209.

Carrara, L.A. \& Faria, L.C.P. 2012. Aves de floresta da Serra do Cipó: Mata Atlântica da Cadeia do Espinhaço. Cotinga, 34: 43-56.

Centrón, S. 2009a. Nuevos registros de especies amenazadas. Urutaú Electrónico, 7(1): 3.

Centrón, S. 2009b. Estancia La Graciela - Misiones, Paraguay. Urutaú Electrónico, 7(4): 8-10.

Centrón, S. 2009c. Salida de observación de aves de pastizales en Barrerito. Urutaú Electrónico, 7(9): 6.

Centrón, S. \& del Castillo, H. 2011. Viaje a las IBAs del sur. Urutaú Electrónico, $9(4): 6-9$.

Chebez, J.C.; Rey, N.R.; Barbaskas, M. \& Di Giacomo, A.G. 1999. Las aves de los Parques Nacionales de la Argentina. Buenos Aires, Administración de Parques Nacionales, Asociación Ornitológica del Plata.

Chubb, C. 1910. On the birds of Paraguay: Part IV. Ibis, $9^{\text {th }}$ series, 16(28): 571-647.

Cockburn, A. 2006. Prevalence of different modes of parental care in birds. Proceedings of the Royal Society B, 273: 1375-1383.

Codesido, M. \& Fraga, R.M. 2009. Distribution of threatened grassland passerines of Paraguay, Argentina and Uruguay, with new locality records and notes on their natural history and habitat. Ornitología Neotropical, 20(4): 585-595.

Conselho Estadual de Política Ambiental (COPAM). 2010. Lista das espécies da fauna ameaçadas de extinção no estado de Minas Gerais. Deliberação Normativa COPAM № 147 de 30 de abril de 2010. Diário do Executivo Minas Gerais, 04 de maio de 2010.

Cory, C.B. \& Hellmayr, C.E. 1927. Catalogue of birds of the Americas and the adjacent islands. Part V. Field Museum of Natural History, Zoological Series, 13:1-517. (Publication, 242)

Darrieu, C.A. \& Camperi, A.R. 1992. Estudio de una colección de aves de Corrientes. III. (Tyrannidae). Hornero, 13(3): 219-224.

del Castillo, H. \& Centrón, S. 2010. Aves del otoño bajo la lluvia en Kangüery. Urutaú Electrónico, 8(5): 7.

Di Giacomo, A.G. 1996. Biología reproductiva del Tachurí Coludo Culicivora caudacuta. In: Reunión Argentina de Ornitología, 9º. Libro de Resúmenes. Buenos Aires, Asociación Ornitológica del Plata. Pp. 16.

Di Giacomo, A.G. 2005. Culicivora caudacuta. In: Di Giacomo, A.G. \& Krapovickas, S.F. (Eds.). Historia natural y paisaje de la Reserva El Bagual, Provincia de Formosa, Argentina. Inventario de la faun a de vertebrados y de Ia flora vascular de un área protegida del Chaco Húmedo. Aves Argentinas/ Asociación Ornitológica del Plata. Pp. 342-343. (Temas de Naturaleza y Conservación 4)

Di Giacomo, A.G.; Di Giacomo, A.S. \& Reboreda, J.C. 2011. Breeding biology and reproductive success of threatened Sharp-tailed Tyrant (Culicivora 
caudacuta) on the Chaco region of Argentina. In: Congreso de Ornitología Neotropical, $9^{\circ}$ y Congreso Peruano de Ornitología, $8^{\circ}$. Libro de Resúmenes. Cusco, Unión de Ornitólogos del Perú. Pp. 442.

Di Giacomo, A.S.; De Francesco, M.V. \& Coconier, E.G. (Eds.). 2007. Áreas importantes para la conservación de las aves en Argentina. Sitios prioritarios para la conservación de la biodiversidad. Temas de Naturaleza y Conservación 5: 1-514. Edición revisada y corregida. Buenos Aires, Aves Argentinas/Asociación ornitológica del Plata.

Dornas, T. \& Crozariol, M.A. 2012. Aves associadas a ambientes de veredas na Estação Ecológica Serra Geral do Tocantins com novos registros para a região e nota sobre a população local de Culicivora caudacuta. Atualidades Ornitológicas, 169: 54-65.

Dornas, T. \& Pascoal, W. 2019. Expansão de distribuição geográfica para a região do Jalapão de três espécies de Passeriformes encontradas no cerrado brasileiro. Cotinga, 41: 81-86.

Esclarski, P.; Gildo, W.L. \& Zanon, C.M.V. 2011. Avifauna do campus CESUMAR. In: EPCC - Encontro Internacional de Produção Científica Cesumar, $7{ }^{\circ}$. Anais. Maringá, Editora CESUMAR.

Esquivel-M., A.; Velázquez, M.C.; Bodrati, A.; Fraga, R.; del Castillo, H.; Klavins, J.; Clay, R.P.; Madroño, A. \& Peris, S.J. 2007. Status of the avifauna of San Rafael National Park, one of the last large fragments of Atlantic Forest in Paraguay. Bird Conservation International, 17: 301-317.

Esteban, J.G. 1953. Nuevas localidades para aves argentinas. Acta Zoologica Lilloana, 13: 349-362.

Felizola, E.R \& Azevedo, R.H.V. (Eds.). 2013. Plano de manejo da Área de Relevante Interesse Ecológico (ARIE) Cruls. Encarte 3 - Diagnóstico Socioambiental. Brasília, Greentec Tecnologia Ambiental.

Ferreira, G.A.;Paniago, L.P.M.; Campos, E.H.M.\& Melo, C. 2015. Monitoramento populacional de espécies de aves endêmicas e ameaçadas de extinção do cerrado no Triângulo Mineiro (MG). In: Congresso Brasileiro de Ornitologia, $22^{\circ}$. Resumos. Manaus, Sociedade Brasileira de Ornitologia. Pp. 256-257.

Fitzpatrick, J.F. 2004. Family Tyraniidae (Tyrant-Flycatchers). In: del Hoyo, J.; Elliot, A. \& Sargatal, J. (Eds.). Handbook of the Birds of the World. Volume 9: Cotingas to Pipits and Wagtails. Barcelona, Lynx Edicions. Pp. 170-463.

Fontana, C.S.; Bencke, G.A. \& Reis, R.E. (Eds.). 2003. Livro vermelho da fauna ameaçada de extinção no Rio Grande do Sul. Porto Alegre, EDIPUCRS.

Fontana, C.S.; Rovedder, C.E.; Repenning, M. \& Gonçalves, M.L. 2008. Estado atual do conhecimento e conservação da avifauna dos Campos de Cima da Serra do sul do Brasil, Rio Grande do Sul e Santa Catarina. Revista Brasileira de Ornitologia, 16(4): 281-307.

Fraga, R.M. 1996. Aves. Pp. 155-219. In: García Fernandez, J.J.; Fraga, R.M.; Díaz, G.B. \& Baigún, R.J. (Eds.). Libro rojo de mamíferos y aves amenazados de la Argentina. Buenos Aires, Fundación para la Conservación de las Especies y Medio Ambiente.

Fundação Pró-Natureza (FUNATURA). 1994. Plano de manejo do Santuário de Vida Silvestre São Miguel. Braślia, Editora Linker Sun.

Godoi, M.N.; Morante-Filho, J.C.; Módena, É.S.; Faxina, C.; Tizianel, F.A.T.; Bocchese, R.; Pivatto, M.A.C.; Nunes, A.P. \& Posso, S.R. 2013. Birds of upper Paraná river basin in the state of Mato Grosso do Sul, Brazil. Revista Brasileira de Ornitologia, 21(3): 176-204.

Graham, G.L.; Graves, G.R.; Schulenberg, T.S. \& 0'Neill, J.P. 1980. Seventeen bird species new to Peru from the Pampas de Heath. The Auk, 97(3): 366-370.

Gressler, D.T. \& Krüger, M.M. 2005. Inventário da avifauna em capinzais no município de São Francisco do Assis, campos sulinos do Rio Grande do Sul. In: Congresso Brasileiro de Ornitologia, $12^{\circ}$. Resumos. Belém, Universidade Federal do Pará. Pp. 100.

Griesser, M. \& Suzuki, T.N. 2016. Occasional cooperative breeding in birds and the robustness of comparative analyses concerning the evolution of cooperative breeding. Zoological Letters, 2(1): 1-11.
Hartert, E. \& Venturi, S. 1909. Notes sur les oiseaux de la République Argentine. Novitates Zoologicae, 16(2): 159-267.

Hass, A. \& Silva e Silva, R. 2008. Culicivora caudacuta. In: Machado, A.B.M.; Drummond, G.M. \& Paglia, A.P. (Org.). Livro Vermelho das Espécies Ameaçadas de Extinção. Brasília, MMA \& Fundação Biodiversitas. v. 2, p. 628-629.

Hayes, F.E. 1995. Status, distribution and biogeography of the birds of Paraguay. Albany, American Birding Association. (Monographs in Field Ornithology, n. 1).

Hoffmann, D.; Vasconcelos, M.F.; Lopes, L.E. \& Rodrigues, M. 2007. Comportamento de forrageamento e dieta de Polystictus superciliaris (Aves, Tyrannidae) no sudeste do Brasil. Iheringia. Série Zoologia, 97(3): 296-300.

Instituto Chico Mendes de Conservação da Biodiversidade (ICMBio). 2018. Livro vermelho da fauna Brasileira ameaçada de extinção - Aves. Brasília, ICMBio. v. 3.

Instituto Estadual de Florestas (IEF). 2016. Plano de manejo do Parque Estadual Serra do Intendente e Parque Natural Municipal do Tabuleiro. Belo Horizonte, Detzel Consulting.

Kanegae, M.F. 2011. Population size of threatened and endemic birds of the cerrado in Estação Ecológica de Itirapina, a fragmented area in the state of São Paulo, Brazil. Bird Conservation International, 22: 144-154.

Krauczuk, E.R. 1997. Levantamiento cuantitativo de aves de pastizal en Campo San Juan, Santa Ana, Misiones, Argentina. Pp. 160. In: Congresso Brasileiro de Ornitologia, $6^{\circ}$. Resumos. Belo Horizonte, Universidade Federal de Minas Gerais.

Krauczuk, E.R. 2005. Aves do Inta-Campo anexo ao Zaiman, e do campus da Universidade Nacional de Misiones, Posadas, Misiones, Argentina. Atualidades Ornitológicas, 126: 17-39.

Krauczuk, E.R. 2006. Las aves del Gran Posadas (Misiones, Argentina) y comentarios sobre especies de interes. Atualidades Ornitológicas, 134: $1-21$.

Laubmann, A. 1940. Wissenschaftliche Ergebnisse der Deutschen Gran ChacoExpedition: Die vögel von Paraguay. Sttutgart, Strecker und Schröder. v. 2.

Lillo, M. 1909. Notas ornitológicas. Apuntes de Historia Natural, Buenos Aires, 1(2): $21-26$

Lins, L.V. 1998. Culicivora caudacuta. Pp. 337-338. In: Machado, A.B.M.; Fonseca, G.A.B.; Machado, R.B.; Aguiar, L.M.S. \& Lins, L.V. (Eds.). Livro vermelho das espécies ameaçadas de extinção da fauna de Minas Gerais. Belo Horizonte, Fundação Biodiversitas.

Lombardi, V.T.; Faetti, R.G.; D’Angelo-Neto, S.; Vasconcelos, M.F. \& Gussoni, C.O.A. 2010. Notas sobre a nidificação de aves brasileiras raras e/ou pouco conhecidas. Cotinga, 32(1): 131-136.

Lombardi, V.T.; Santos, K.K.; D’Angelo-Neto, S.; Mazzoni, L.G.; Rennó, B.; Faetti, R.G.; Epifânio, A.D. \& Miguel, M. 2012. Registros notáveis de aves para 0 sul do Estado de Minas Gerais, Brasil. Cotinga, 34: 32-45.

Lopes, L.E.; Malacco, G.B.; Alteff, E.F.; Vasconcelos, M.F.; Hoffmann, D. \& Silveira, L.F. 2009. Range extensions and conservation of some threatened or little known Brazilian grassland birds. Bird Conservation International, 19: 1-11. DOI

Lopes, L.E.; Malacco, G.B.; Vasconcelos, M.F.; Carvalho, C.E.A.; Duca, C.; Fernandes, A.M.; D'Angelo-Neto, S.; Marini, M.Â. 2008. Aves da região de Unaí e Cabeceira Grande, noroeste de Minas Gerais, Brasil. Revista Brasileira de Ornitologia, 16(3): 193-206.

Madroño Nieto, A. \& Esquivel, E.Z. 1997. Noteworthy records and range extensions of some birds from the Reserva Natural del Bosque Mbaracayú (Mbaracayú Forest Nature Reserve), Departamento de Canindeyú, Paraguay. Bulletin of the British Ornithologists' Club, 117(3): 166-176.

Malacco, G.B.; Valadão, R.M.; Franchin, A.G.; Marçal Júnior, 0. \& Zanzini, A.C.S. 2003. Registro de Culicivora caudacuta (Tyrannidae) na região do alto 
Paranaíba, Minas Gerais. In: Congresso Brasileiro de Ornitologia, $11^{\circ}$. Livro de Resumos. Feira de Santana, Universidade Estadual de Feira de Santana. Pp. 97.

Marini, M.Â.; Borges, F.J.A.; Lopes, L.E.; Sousa, N.O.M.; Gressler, D.T.; Santos, L.R.; Paiva, L.V.; Duca, C.; Manica, L.T.; Rodrigues, S.S.; França, L.F.; Costa, P.M.; França, L.C.; Heming, N.M.; Silveira, M.B.; Pereira, Z.P.; Lobo, Y.; Medeiros, R.C.S. \& Roper, J.J. 2012. Breeding biology of birds in the cerrado of central Brazil. Ornitología Neotropical, 23(3): 385-405.

Marino, G.D.; Miñarro, F.; Zaccagnini, M.E. \& López-Lanús, B. (Eds.). 2013. Pastizales y sabanas del cono sur de Sudamerica: Iniciativas para su conservación en la Argentina. Buenos Aires, Aves Argentinas/Asociación Ornitológica del Plata, Fundación Vida Silvestre Argentina e Instituto Nacional de Tecnología Agropecuaria. (Monografia de Aves Argentinas n. 9).

Mattos, G.T.; Andrade, M.A. \& Freitas, M.V. 1991. Acréscimos à lista de aves do Estado de Minas Gerais. Revista SOM, 39: 3-7.

Mazzoni, L.G.; Perillo, A.; Malacco, G.B.; Almeida, T.0.; Peixoto, H.J.C.; Souza, T.0.; Dutra, E.C. \& França, E.A. 2012. Aves, Micropygia schomburgkii (Schomburgk, 1848), Veniliornis mixtus (Boddaert, 1783), Culicivora caudacuta (Vieillot, 1818) and Coryphaspiza melanotis (Temminck, 1822): documented records in the southern Espinhaço Range, Minas Gerais, Brazil. Check List, 8(1): 138-142.

Melo, V.A. 1997. Poleiros artificiais e dispersão de sementes por aves em uma área de reflorestamento, no estado de Minas Gerais. M.Sc. Dissertation. Viçosa, Universidade Federal de Viçosa.

Mikich, S.B. \& Bérnils, R.S. (Eds.). 2004. Livro vermelho da fauna ameaçada de extinção no estado do Paraná. Curitiba, Instituto Ambiental do Paraná.

Milat, J.; Moschione, F. \& Klimaitis, J. 1985. Azor Variado, Tachurí Coludo y Anó Grande en Entre Ríos. Nuestras Aves, 6: 6-7.

Ministerio de Ambiente y Desarrollo Sustentable \& Aves Argentina. 2017. Categorización de las aves de la Argentina (2015). Buenos Aires, Ministerio de Ambiente y Desarrollo Sustentable \& Aves Argentina.

Miyaji, E.E. 2013. Estrutura, composição e distribuição da avifauna em mosaico de ambientes na região da foz do Rio Aguapeí, SP. M.Sc. Dissertation. Campo Grande, Universidade Federal de Mato Grosso do Sul. 49p.

Modernel, P.; Rossing, W.A.H.; Corbeels, M.; Dogliotti, S.; Picasso, V. \& Tittonell, P. 2016. Land use change and ecosystem service provision in the Pampas and Campos grasslands of southern South America. Environmental Research Letters, 11, 113002.

Morante-Filho, J.C.; Posso, S.R.; Cunha, N.L. \& Bueno, F.A. 2014. Tyrant flycatchers community in a mosaic of habitats of cerrado, Brazil. NorthWestern Journal of Zoology, 10(2): 425-434.

Motta-Jr., J.C.; Ritter, A.C.; Ferrari, A.; Paschotto, F.R.; De Sordi, L.; Morandini, R.S.; Barros, F.M.; Ruffino, P.H.P. \& Braga, A.C.R. 2020. Aves e seus ambientes na Estação Ecológica de Itirapina, SP. São Paulo, Instituto de Biociências da Universidade de São Paulo.

Moura, A.S. \& Corrêa, B.S. 2012. Aves ameaçadas e alguns registros notáveis para Carrancas, sul de Minas Gerais, Brasil. Atualidades Ornitológicas, 165: 4-9.

Moura, A.S.; Corrêa, B.S.; Santos, D.W.M. \& Marques, R.H.R. 2011. Novos registros ornitológicos para Quartel São João, município de Quartel Geral, MG, com novas áreas de ocorrência das espécies ameaçadas, Taoniscus nanus (Tinamidae), Urubitinga coronata (Accipitridae), Culicivora caudacuta (Tyrannidae) e Poospiza cinerea (Emberizidae). Atualidades Ornitológicas, 162: 51-56.

Occhialini, D.S. (Ed.). 2010. Lista das espécies da fauna ameaçada de extinção em Santa Catarina. Relatório Técnico Final. Fundação do Meio Ambiente.

Pacheco, J.F. \& Olmos, F. 2010. As aves do Tocantins, Brasil - 2: Jalapão. Revista Brasileira de Ornitologia, 18(1): 1-18.

Pacheco, J.F., Parrini, R., Lopes, L.E. \& Vasconcelos, M.F. 2008. A avifauna do Parque Estadual do Ibitipoca eáreas adjacentes, Minas Gerais, Brasil, uma revisão crítica dos registros prévios e comentários sobre biogeografia e conservação. Cotinga, 30: 16-32.

Parera, A. (Ed.). 2004. Fauna del Iberá: composición, estado de conservación y propuestas de manejo. Corrientes, Fundación Biodiversidad Argentina.

Parker III, T.A. \& Rocha 0., 0. 1991. La avifauna del Cerro San Simon, una localidad de campo rupestre aislado en el Depto. Beni, noreste Boliviano. Ecología en Bolivia, 17: 15-29.

Parker III, T.A. \& Willis, E.0. 1997. Notes on three tiny grassland flycatchers, with comments on the disappearance of South American fire-diversified savannas. In: Remsen-Jr., J. (Ed.). Studies in Neotropical Ornithology Honoring Ted Parker. Ornithological Monographs, 48: 549-555.

Parker III, T.A.; Castillo, A.; Gell-Mann, M. \& Rocha, 0. 1991. Records of new and unusual birds from northern Bolivia. Bulletin of the British Ornithologists' Club, 111(3): 120-138.

Peixoto, H.J.C. 2014. Ecologia e conservação de aves campestres ameaçadas de extinção no sul de Minas Gerais, Brasil. M.Sc. Dissertation. Viçosa, Universidade Federal de Viçosa. 100p.

Pellin, A.; Fernandes, H.M. \& Scheffler, S.M. (Org.) 2008. Plano de manejo da reserva particular do patrimônio natural Fazenda da Barra. Bonito, Conservação Internacional do Brasil/Associação de Proprietários de RPPNs de Mato Grosso do Sul/Agropecuária Projecto Vivo Ltda.

Pelzeln, A. von. 1868-1870. Zur Ornithologie Brasiliens. Resultate von Johann Natterers Reisen in den Jahren 1817 bis 1835. Parts I-IV. Viena, A. Pichler's Witwe \& Sohn.

Pereira, K.D.L. \& Silva, R. 2009. Levantamento da avifauna da area urbana de Anápolis, Goiás. Ensaios e Ciência: Ciências Biológicas, Agrárias e da Saúde, 13(2): 33-46.

Petermann, P.; Oliveira, C.R.A.; Bernardon, B.; Oliveira, F.F. \& Nabuco, H.C.G. 2001. Aves de uma área do cerrado no divisor continental entre as bacias de La Plata e do Amazonas, sul do Mato Grosso. Pp. 308-309. In: Straube. F.C. (Ed.). Ornitologia sem fronteiras, incluindo os resumos do IX Congresso Brasileiro de Ornitologia. Curitiba, Pontifícia Universidade Católica do Paraná.

Pinto, 0.M.0. 1944. Catálogo das aves do Brasile a lista dos exemplares existentes na coleção do Departamento de Zoologia, $2^{a}$ parte. Ordem Passeriformes (continuação): superfamilia Tyrannoidea e subordem Passeres. São Paulo, Departamento de Zoologia, Secretaria da Agricultura, Indústria e Comércio

Pivatto, M.A.C.; Manço, D.G.; Straube, F.C.; Urben-Filho, A. \& Milano, M. 2006. Aves do Planalto da Bodoquena, estado do Mato Grosso do Sul (Brasil). Atualidades Ornitológicas, 129: 28-53.

Reinert, B.L.; Bornschein, M.R. \& Flores, J.M. 1998. Aves do Parque Nacional da Chapada dos Veadeiros, Goiás (Brasil). Pp. 46. In: Resumos do VII Congresso Brasileiro de Ornitologia. Rio de Janeiro, Universidade do Estado do Rio de Janeiro.

Repenning, M.; Rovedder, C.E. \& Fontana, C.S. 2010. Distribuição e biologia de aves nos campos de altitude do sul do Planalto Meridional Brasileiro. Revista Brasileira de Ornitologia, 18(4): 283-306.

Ribon, R.; Estevão, G.R.M.; Simon, J.E.; Silva, N.F.; Pacheco, S. \& Pinheiro, R.T. 1995. Aves do cerrado de Três Marias, estado de Minas Gerais. Revista Ceres, 42(242): 344-352.

Rocha, V.J.; Machado, R.A.; Filipaki, S.A.; Fier, I.S.N. \& Pucci, J.A.L. 2003. A biodiversidade da fazenda Monte Alegre da Klabin S.A. no estado do Paraná. In: Congresso Florestal Brasileiro, $8^{\circ}$. Anais. São Paulo.

Rodrigues, F.H.G.; Hass, A.; Marini-Filho, 0.J.; Guimarães, M.M. \& Bagno, M.A. 1999. A new record of White-winged Nightjar Caprimulgus candicans in Emas National Park, Goiás, Brazil. Cotinga, 11: 83-85.

Rodrigues, M.; Freitas, G.H.S.; Costa, L.M.; Dias, D.F.; Varela, M.L.M. \& Rodrigues, L.C. 2011. Avifauna, Alto do Palácio, Serra do Cipó National Park, state of Minas Gerais, southeastern Brazil. Check List, 7: 151-161. 
Rovedder, C.E.; Reppening, M. \& Fontana, C.S. 2007. Novos registros de ocorrência do papa-moscas-do-campo Culicivora caudacuta (Tyrannidae) para 0 estado do Rio Grande do Sul, Brasil. In: Congresso Brasileiro de Ornitologia, 15. Resumos. Porto Alegre, PUCRS. Pp. 151-152.

Santos, R.L.C; Sobral, L.G.S.; Araújo, R.V.V. \& Fosfertil, E.T. 2002. Produção de fosfato no Brasil: Complexo de Mineração de Tapira/Fosfertil. In: Encontro Nacional de Tratamento de Minérios e Metalurgia Extrativa, $19^{\circ}$. Anais. Recife.

Santos, R.E.F. 2007. Novo registro documentado do galito Alectrurus tricolor (Vieillot, 1816) para o estado do Paraná, Brasil. Atualidades Ornitológicas, 140: 12-13.

Schmitt, C.G. \& Schmitt, D.C. 1987. Extensions of range of some Bolivian birds. Bulletin of the British Ornithologists' Club, 107(3): 129-134.

Sigrist, T. 2004. Aves do Brasil: uma visão artística. Vinhedo, Avis Brasilis. Sigrist, T. 2007. Guia de campo: aves do Brasil oriental. Vinhedo, Avis Brasilis.

Silva e Silva, R. 2004. Magia no cerrado: aves na imensidão. São Paulo, Editora DBA.

Silva e Silva, R. 2006. Biologia reprodutiva de Culicivora caudacuta (Tyrannidae) em Tapira, MG. In: Congresso Brasileiro de Ornitologia, $14^{\circ}$. Resumos. Ouro Preto, Universidade Federal de Ouro Preto, Sociedade Brasileira de Ornitologia.

Silva, J.M.C., \& Oniki, Y. 1988. Lista preliminar da avifauna da estação ecológica Serra das Araras, Mato Grosso, Brasil. Boletim do Museu Paraense Emílio Goeldi, Série Zoologia, 4(2): 123-143.

Silveira, L.F. 1998. The birds of Serra da Canastra National Park and adjacent areas, Minas Gerais, Brazil. Cotinga, 10: 55-63.

Smith, P. 2017. The juvenile plumage of Sharp-tailed Tyrant Culicivora caudacuta (Aves: Tyrannidae). Revista Brasileira de Ornitologia, 25(2): 122-124.

Soria-Auza, R.W. \& Hennessey, A.B. 2005. Áreas importantes para la conservación de las aves en Bolivia. In: BirdLife International \&
Conservation International (Eds.). Áreas importantes para la conservación de las aves en los Andes tropicales: sitios prioritarios para la conservación de la biodiversidad. Quito, BirdLife International. Pp. 57-116. (Serie de Conservación de BirdLife № 14).

Sousa, N.0. de M. \& Marini, M.Â. 2007. Biologia de Culicivora caudacuta (Aves: Tyrannidae) no Cerrado, Brasília, DF. Revista Brasileira de Ornitologia, 15(4): 569-573.

Souza, T.0.; Teixeira, F.D.; Oliveira, L.A.S.; Oliveira, A.C.S.; Garcia, F.I.A.; Mesquita, E.P.; Silva, G.G.R.; Oliveira, A.P.M.; Passos, M.F.O. \& Silva, A.G. 2018. Levantamento ornitológico do município de Pompéu, região central de Minas Gerais, Brasil. Atualidades Ornitológicas, 202: 49-66.

Superintendência Regional de Meio Ambiente (SUPRAM). 2019. Parecer Técnico № 0538080/2019. Uberlândia, Governo de Minas Gerais.

Temminck, C.J. 1822. Nouveau recueil de planches colorieés d'oiseaux, pour servir de suite et de complément aux planches enluminées de Buffon. Paris, G. Levrault. Livr. 28, pl. 167, fig. 3.

Vieillot, L.J.P. 1818. Nouveau dictionnaire d'histoire naturelle. Paris, Chez Deterville. Tome XXI.

Wagener, T.L.S.; Santos, L.E.S.; Almeida, R.A.; Prestes, N.P. \& Krügel, M.M. 2019. Gubernetes yetapa (Aves: Tyrannidae) as a nest helper: a report. In: Congresso Brasileiro de Ornitologia, $26^{\circ}$. Livro de Resumos. Vila Velha, ES. Pp. 130.

Wetmore, A. 1926. Observations on the birds of Argentina, Paraguay, Uruguay, and Chile. Bulletin. United States National Museum, 133: 1-448.

White, E.W. 1882. Notes on birds collected in the Argentine Republic. Proceedings of the Scientific Meetings of the Zoological Society of London, 4:591-629.

WikiAves. 2020. WikiAves, a Enciclopédia das Aves do Brasil. Available: $\underline{\text { http:// }}$ www.WikiAves.com.br. Access: 01/06/2020.

Willis, E.0. \& Oniki, Y. 2003. Aves do Estado de São Paulo. Rio Claro, Divisa. 


\section{APPENDIX 1}

Records of Sharp-tailed Tyrant Culicivora caudacuta. Record: $\mathrm{O}=$ observation, $\mathrm{P}=$ photography, $\mathrm{S}=\mathrm{specimen}, \mathrm{V}=$ vocalization recorded. Source: AMNH = American Museum of Natural History, New York, USA; ANSP = Academy of Natural Sciences, Philadelphia, USA; CM = Carnegie Museum of Natural History, Pittsburgh, USA; DZUFMG = Departamento de Zoologia da Universidade Federal de Minas Gerais, Belo Horizonte, Brazil; FMNH = Field Museum of Natural History, Chicago, USA; IBGE = Coleção Ornitológica da Reserva Ecológica do IBGE, Brasília, Brazil; LSUMZ = Louisiana State University, Museum of Natural Science, Baton Rouge, USA; MACN = Museo Argentino de Ciencias Naturales "Bernardino Rivadavia", Buenos Aires, Argentina; MCNA = Museu de Ciências Naturais da Pontifícia Universidade Católica de Minas Gerais, Belo Horizonte, Brazil; MCP = Museu de Ciências da Pontifícia Universidade Católica do Rio Grande do Sul, Porto Alegre, Brazil; MCZ = Museum of Comparative Zoology, Cambridge, USA; MHNCI = Museu de História Natural Capão da Imbuia, Curitiba, Brazil; MHNSCP = Museo de Historia Natural de la Sociedad Científica del Paraguay, Asunción, Paraguay; MNK = Museo de Historia Natural Noel Kempff Mercado, Santa Cruz de la Sierra, Bolivia; MNRJ = Museu Nacional, Rio de Janeiro, Brazil; MPEG = Museu Paraense Emílio Goeldi, Belém, Brazil; MZUSP = Museu de Zoologia da Universidade de São Paulo, São Paulo, Brazil; NHMUK = Natural History Museum, Tring, UK; NMW = Naturhistorisches Museum Wien, Wien, Austria; RMNH = Rijksmuseum van Natuurlijke Historie, Leiden, The Netherlands; SMF = Senckenberg Naturmuseum Frankfurt, Germany; USNM = United States National Museum, Washington, USA; ZSM = Zoologische Staatssammlung München, Germany; EB = eBird database; ML = Macaulay Library database; WA = WikiAves database; XC = XenoCanto database. Personal observations: DB = Dante Buzzetti; FO = Fabio Olmos; JFP = José Fernando Pacheco; JNC = Juvêncio Nunes da Costa; RSS = Robson Silva e Silva.

\begin{tabular}{|c|c|c|c|c|}
\hline Country, State/Province/Departament, Municipality, Locality & Latitude & Longitude & Record & Source \\
\hline \multicolumn{5}{|l|}{ BRAZIL } \\
\hline \multicolumn{5}{|l|}{ Amazonas } \\
\hline Canutama, Igarapé Assuã, BR 319 & $08^{\circ} 05^{\prime} S$ & $63^{\circ} 45^{\prime} \mathrm{W}$ & $S, P$ & MZUSP, WA \\
\hline Humaitá & $07^{\circ} 35^{\prime} \mathrm{S}$ & $63^{\circ} 14^{\prime} \mathrm{W}$ & 0 & $E B$ \\
\hline \multicolumn{5}{|l|}{ Maranhão } \\
\hline Alto Parnaíba, Estiva & $09^{\circ} 35^{\prime} \mathrm{S}$ & $46^{\circ} 25^{\prime} \mathrm{W}$ & $S$ & MPEG \\
\hline \multicolumn{5}{|l|}{ Tocantins } \\
\hline Almas, RPPN Fazenda Minnehaha & $11^{\circ} 08^{\prime} \mathrm{S}$ & $47^{\circ} 08^{\prime} \mathrm{W}$ & 0 & (Dornas \& Crozariol, 2012) \\
\hline Araguacema, Rio Piranha & $08^{\circ} 48^{\prime} S$ & $49^{\circ} 25^{\prime} \mathrm{W}$ & 0 & JFP \& F0 \\
\hline Lizarda, $15 \mathrm{~km}$ East & $09^{\circ} 27^{\prime} S$ & $46^{\circ} 35^{\prime} \mathrm{W}$ & 0 & (Pacheco \& Olmos, 2010) \\
\hline Mateiros & $10^{\circ} 22^{\prime} \mathrm{S}$ & $46^{\circ} 08^{\prime} \mathrm{W}$ & 0 & (Dornas \& Pascoal, 2019) \\
\hline Mateiros & $10^{\circ} 23^{\prime} \mathrm{S}$ & $46^{\circ} 03^{\prime} \mathrm{W}$ & P & WA, (Dornas \& Pascoal, 2019) \\
\hline Mateiros & $10^{\circ} 27^{\prime} S$ & $46^{\circ} 08^{\prime} \mathrm{W}$ & 0 & (Dornas \& Pascoal, 2019) \\
\hline Mateiros, Jalapão State Park, lake near the dunes & $10^{\circ} 34^{\prime} \mathrm{S}$ & $46^{\circ} 40^{\prime} \mathrm{W}$ & 0 & RSS, (Pacheco \& Olmos, 2010) \\
\hline Mateiros, Jalapão State Park, near Pousada do Jalapão & $10^{\circ} 18^{\prime} S$ & $46^{\circ} 56^{\prime} \mathrm{W}$ & 0 & RSS \& JFP \\
\hline Miracema do Tocantins & $09^{\circ} 34^{\prime} S$ & $48^{\circ} 23^{\prime} \mathrm{W}$ & $\mathrm{P}$ & WA \\
\hline Ponte Alta do Tocantins & $10^{\circ} 44^{\prime} \mathrm{S}$ & $47^{\circ} 32^{\prime} \mathrm{W}$ & $P$ & WA \\
\hline Rio da Conceição, Serra Geral do Tocantins Ecological Station & $11^{\circ} 14^{\prime} \mathrm{S}$ & $46^{\circ} 53^{\prime} \mathrm{W}$ & $P$ & WA, (Dornas \& Crozariol, 2012) \\
\hline Rio Sono & $09^{\circ} 25^{\prime} \mathrm{S}$ & $47^{\circ} 15^{\prime} \mathrm{W}$ & P & WA, (Dornas \& Pascoal, 2019) \\
\hline Rio Sono, headwaters of Ribeirão Areias & $09^{\circ} 48^{\prime} S$ & $47^{\circ} 34^{\prime} \mathrm{W}$ & 0 & (Dornas \& Pascoal, 2019) \\
\hline Rio Sono, headwaters of Ribeirão Monte Santo & $09^{\circ} 44^{\prime} S$ & $47^{\circ} 29^{\prime} \mathrm{W}$ & $P, V$ & WA, XC, (Dornas \& Pascoal, 2019) \\
\hline Rio Sono, Mansinha & $09^{\circ} 20^{\prime} \mathrm{S}$ & $47^{\circ} 16^{\prime} \mathrm{W}$ & 0 & (Dornas \& Pascoal, 2019) \\
\hline \multicolumn{5}{|l|}{ Bahia } \\
\hline $\operatorname{cocos}$ & $12^{\circ} 43^{\prime} \mathrm{S}$ & $44^{\circ} 33^{\prime} \mathrm{W}$ & $P$ & WA \\
\hline Correntina, Fazenda Jatobá & $13^{\circ} 45^{\prime} \mathrm{S}$ & $45^{\circ} 36^{\prime} \mathrm{W}$ & 0 & (Antas et al., 1993) \\
\hline Jaborandi, Pousada Trijunção, RPPN Lagoa do Formoso & $14^{\circ} 47^{\prime} \mathrm{S}$ & $45^{\circ} 56^{\prime} \mathrm{W}$ & $P$ & WA \\
\hline Mucugê, Gerais of Chapada Diamantina & $13^{\circ} 00^{\prime} \mathrm{S}$ & $41^{\circ} 24^{\prime} \mathrm{W}$ & $P, V$ & $E B, W A, X C$ \\
\hline \multicolumn{5}{|l|}{ Goiás } \\
\hline Água Fria de Goiás, Fazenda Nossa Senhora Aparecida & $14^{\circ} 47^{\prime} \mathrm{S}$ & $47^{\circ} 45^{\prime} \mathrm{W}$ & $P$ & WA, EB \\
\hline Águas Lindas de Goiás, Lago do Descoberto & $15^{\circ} 44^{\prime} \mathrm{S}$ & $48^{\circ} 13^{\prime} \mathrm{W}$ & 0 & JNC \\
\hline Alto Paraíso de Goiás, Chapada dos Veadeiros National Park & $14^{\circ} 05^{\prime} S$ & $47^{\circ} 40^{\prime} \mathrm{W}$ & $P, V$ & (Reinert et al., 1998), (Braz, 2008), WA \\
\hline Alto Paraíso de Goiás, Fazenda dos Anões & $14^{\circ} 19^{\prime} S$ & $47^{\circ} 30^{\prime} \mathrm{W}$ & P & $E B$ \\
\hline Alto Paraíso de Goiás, Fazenda Chapadão das Almas, Rio das Almas & $13^{\circ} 58^{\prime} \mathrm{S}$ & $47^{\circ} 27^{\prime} \mathrm{W}$ & P & DB \\
\hline Alto Paraíso de Goiás, Fazenda Firmeza & $14^{\circ} 17^{\prime} S$ & $47^{\circ} 29^{\prime} \mathrm{W}$ & 0 & $E B$ \\
\hline Alto Paraíso de Goiás, Fazenda São Bento & $14^{\circ} 06^{\prime} S$ & $47^{\circ} 28^{\prime} \mathrm{W}$ & 0 & $E B$ \\
\hline Alto Paraíso de Goiás, Fazenda Volta da Serra & $14^{\circ} 10^{\prime} S$ & $47^{\circ} 46^{\prime} \mathrm{W}$ & 0 & $E B$ \\
\hline Alto Paraíso de Goiás, near Ribeirão São Miguel & $14^{\circ} 09^{\prime} \mathrm{S}$ & $47^{\circ} 47^{\prime} \mathrm{W}$ & 0 & $E B$ \\
\hline Alto Paraíso de Goiás, Pontezinha & $14^{\circ} 08^{\prime} S$ & $47^{\circ} 31^{\prime} \mathrm{W}$ & P & $E B$ \\
\hline Alto Paraíso de Goiás, Road to Osho Lua & $14^{\circ} 18^{\prime} S$ & $47^{\circ} 39^{\prime} \mathrm{W}$ & 0 & $E B$ \\
\hline Alto Paraíso de Goiás, Road to Rio dos Couros & $14^{\circ} 08^{\prime} S$ & $47^{\circ} 40^{\prime} \mathrm{W}$ & 0 & $\mathrm{~EB}$ \\
\hline
\end{tabular}




\begin{tabular}{|c|c|c|c|c|}
\hline Country, State/Province/Departament, Municipality, Locality & Latitude & Longitude & Record & Source \\
\hline Alto Paraíso de Goiás, Templo Centelha Divina & $14^{\circ} 08^{\prime} \mathrm{S}$ & $47^{\circ} 34^{\prime} \mathrm{W}$ & 0 & EB \\
\hline Anápolis, Boa Vista, Chácara das Rosas & $16^{\circ} 18^{\prime} \mathrm{S}$ & $48^{\circ} 54^{\prime} \mathrm{W}$ & 0 & (Pereira \& Silva, 2009) \\
\hline Anápolis, Trilha Ecológica do Tucano & $16^{\circ} 17^{\prime} \mathrm{S}$ & $48^{\circ} 56^{\prime} \mathrm{W}$ & 0 & (Pereira \& Silva, 2009) \\
\hline Aparecida de Goiânia, Serra das Areias, Rio Dourados & $16^{\circ} 51^{\prime} \mathrm{S}$ & $49^{\circ} 18^{\prime} \mathrm{W}$ & 0 & JNC \\
\hline Campo Alegre de Goiás, Serra do Facão & $17^{\circ} 39^{\prime} \mathrm{S}$ & $47^{\circ} 43^{\prime} \mathrm{W}$ & 0 & JNC \\
\hline Catalão, headwaters of Ribeirão Batalha & $17^{\circ} 32^{\prime} \mathrm{S}$ & $47^{\circ} 27^{\prime} \mathrm{W}$ & $P$ & RSS \\
\hline Cavalcante, Fazenda Piqui & $13^{\circ} 29^{\prime} \mathrm{S}$ & $47^{\circ} 33^{\prime} \mathrm{W}$ & 0 & $E B$ \\
\hline Cavalcante, Road BR-10 & $13^{\circ} 56^{\prime} \mathrm{S}$ & $47^{\circ} 27^{\prime} \mathrm{W}$ & 0 & $E B$ \\
\hline Cavalcante, RPPN Reserva Natural Serra do Tombador & $13^{\circ} 40^{\prime} \mathrm{s}$ & $47^{\circ} 48^{\prime} \mathrm{W}$ & $P$ & WA, (Antonelli-Filho, 2011) \\
\hline Chapadão do Céu & $18^{\circ} 25^{\prime} \mathrm{S}$ & $52^{\circ} 33^{\prime} \mathrm{W}$ & $\mathrm{P}, \mathrm{V}$ & WA \\
\hline Chapadão do Céu, Emas National Park & $18^{\circ} 17^{\prime} \mathrm{S}$ & $52^{\circ} 46^{\prime} \mathrm{W}$ & $P$ & (Rodrigues et al., 1999), DB, RSS \\
\hline Cocalzinho de Goiás & $15^{\circ} 47^{\prime} \mathrm{S}$ & $48^{\circ} 46^{\prime} \mathrm{W}$ & $P$ & WA, JNC \\
\hline Cocalzinho de Goiás, headwaters of Rio Corumbá & $15^{\circ} 51^{\prime} \mathrm{s}$ & $48^{\circ} 45^{\prime} \mathrm{W}$ & 0 & JNC \\
\hline Cristalina & $16^{\circ} 46^{\prime} \mathrm{S}$ & $47^{\circ} 36^{\prime} \mathrm{W}$ & $\mathrm{P}, \mathrm{V}$ & $W A, X C$ \\
\hline Cristalina, Córrego Cristal & $16^{\circ} 51^{\prime} \mathrm{S}$ & $47^{\circ} 22^{\prime} \mathrm{W}$ & 0 & JNC \\
\hline Jataí & $17^{\circ} 52^{\prime} \mathrm{S}$ & $51^{\circ} 43^{\prime} \mathrm{W}$ & $P$ & WA \\
\hline Mineiros, Emas National Park & $18^{\circ} 08^{\prime} \mathrm{S}$ & $52^{\circ} 54^{\prime} \mathrm{W}$ & $P$ & (Rodrigues et al., 1999), RSS, WA, XC \\
\hline Ouro Verde & $16^{\circ} 11^{\prime} \mathrm{S}$ & $49^{\circ} 11^{\prime} \mathrm{W}$ & 0 & JNC \\
\hline Pirenópolis. Serra dos Pirineus State Park & $15^{\circ} 48^{\prime} \mathrm{S}$ & $48^{\circ} 53^{\prime} \mathrm{W}$ & $\mathrm{P}$ & WA, EB \\
\hline Planaltina & $15^{\circ} 29^{\prime} \mathrm{S}$ & $47^{\circ} 38^{\prime} \mathrm{W}$ & $s$ & MNRJ \\
\hline Rio Quente & $17^{\circ} 45^{\prime} \mathrm{S}$ & $48^{\circ} 44^{\prime} \mathrm{W}$ & 0 & JNC \\
\hline São Domingos, RESEX Recanto das Araras & $13^{\circ} 36^{\prime} \mathrm{S}$ & $46^{\circ} 17^{\prime} \mathrm{W}$ & 0 & $E B$ \\
\hline Taquaral de Goiás, Serra do Brandão & $16^{\circ} 03^{\prime} S$ & $49^{\circ} 33^{\prime} \mathrm{W}$ & 0 & JNC \\
\hline \multicolumn{5}{|l|}{ Distrito Federal } \\
\hline Brasília, Planaltina, Águas Emendadas Ecological Station & $15^{\circ} 32^{\prime} \mathrm{S}$ & $47^{\circ} 36^{\prime} \mathrm{W}$ & 0 & (Sousa \& Marini, 2007) \\
\hline Brasília, Altiplano Leste & $15^{\circ} 50^{\prime} \mathrm{s}$ & $47^{\circ} 43^{\prime} \mathrm{W}$ & $\mathrm{P}, \mathrm{V}$ & $E B, X C, W A, R S S$ \\
\hline Brasilia, ARIE Cruls & $15^{\circ} 44^{\prime} \mathrm{S}$ & $47^{\circ} 55^{\prime} \mathrm{W}$ & 0 & (Felizola \& Azevedo, 2013) \\
\hline Brasilia, Brazlândia and Sobradinho, APA de Cafuringa & $15^{\circ} 32^{\prime} \mathrm{S}$ & $48^{\circ} 04^{\prime} \mathrm{W}$ & 0 & (Bagno et al., 2006) \\
\hline Brasília, Cristo Redentor, RECOR & $15^{\circ} 55^{\prime} \mathrm{S}$ & $47^{\circ} 53^{\prime} \mathrm{W}$ & $S$ & IBGE \\
\hline Brasília, Taguatinga, Brasília National Forest & $15^{\circ} 45^{\prime} \mathrm{S}$ & $48^{\circ} 04^{\prime} \mathrm{W}$ & $\mathrm{P}, 0$ & EB, RSS \\
\hline Brasília, Lago Sul, Brasília Botanical Gardens & $15^{\circ} 52^{\prime} \mathrm{S}$ & $47^{\circ} 49^{\prime} \mathrm{W}$ & 0 & $E B$ \\
\hline Brasilia, Núcleo Bandeirante, Fazenda Água Limpa & $15^{\circ} 57^{\prime} \mathrm{S}$ & $47^{\circ} 56^{\prime} \mathrm{W}$ & $\mathrm{P}, \mathrm{V}$ & $E B, X C$ \\
\hline Brasília, Núcleo Bandeirante, Granja Modelo do Ipê & $15^{\circ} 55^{\prime} \mathrm{S}$ & $47^{\circ} 59^{\prime} \mathrm{W}$ & 0 & $E B$ \\
\hline Brasília, Santa Maria & $16^{\circ} 00^{\prime} \mathrm{s}$ & $47^{\circ} 56^{\prime} \mathrm{W}$ & 0 & JNC \\
\hline Brasília, Brasília National Park & $15^{\circ} 40^{\prime} \mathrm{S}$ & $47^{\circ} 58^{\prime} \mathrm{W}$ & $S, 0$ & MNRJ, (Antas, 1995), EB \\
\hline Brasília, Guará, Guará Ecological Park & $15^{\circ} 49^{\prime} \mathrm{S}$ & $47^{\circ} 58^{\prime} \mathrm{W}$ & $s$ & MNRJ \\
\hline Brasilia, IBGE Ecological Reserve & $15^{\circ} 55^{\prime} \mathrm{S}$ & $47^{\circ} 52^{\prime} \mathrm{W}$ & v & (Braz \& Cavalcanti, 2001), ML \\
\hline \multicolumn{5}{|l|}{ Mato Grosso } \\
\hline Barão de Melgaço, RPPN SESC Pantanal e Entorno & $16^{\circ} 35^{\prime} \mathrm{S}$ & $56^{\circ} 15^{\prime} \mathrm{W}$ & 0 & (Birdlife International, 2020a) \\
\hline Chapada dos Guimarães, Chapada & $15^{\circ} 25^{\prime} \mathrm{S}$ & $55^{\circ} 48^{\prime} \mathrm{W}$ & $s$ & AMNH, NHMUK \\
\hline Itiquira & $17^{\circ} 17^{\prime} \mathrm{S}$ & $53^{\circ} 49^{\prime} \mathrm{W}$ & $\mathrm{P}, \mathrm{V}$ & WA \\
\hline Jaciara, Fazenda Santa Fé & $15^{\circ} 59^{\prime} \mathrm{S}$ & $55^{\circ} 02^{\prime} \mathrm{W}$ & 0 & (Petermann et al., 2001) \\
\hline Porto Estrela, Serra das Araras Ecological Station, Rio Salobo valley & $15^{\circ} 39^{\prime} \mathrm{S}$ & $57^{\circ} 13^{\prime} \mathrm{W}$ & 0 & (Silva \& Oniki, 1988) \\
\hline \multicolumn{5}{|l|}{ Mato Grosso do Sul } \\
\hline Bodoquena, Fazenda Indiana, Rio Salobra & $20^{\circ} 25^{\prime} \mathrm{S}$ & $56^{\circ} 39^{\prime} \mathrm{W}$ & 0 & (Pivatto et al., 2006) \\
\hline Bonito, RPPN Fazenda da Barra & $21^{\circ} 06^{\prime} \mathrm{S}$ & $56^{\circ} 13^{\prime} \mathrm{W}$ & $P$ & WA, (Pellin et al., 2008) \\
\hline Brazilândia, RPPN Cisalpina & $21^{\circ} 16^{\prime} \mathrm{S}$ & $51^{\circ} 55^{\prime} \mathrm{W}$ & 0 & (Godoi et al., 2013), (Morante-Filho et al., 2014) \\
\hline Campo Grande, airport & $20^{\circ} 28^{\prime} \mathrm{S}$ & $54^{\circ} 40^{\prime} \mathrm{W}$ & $P$ & $E B$, WA \\
\hline Costa Rica & $18^{\circ} 18^{\prime} \mathrm{S}$ & $54^{\circ} 54^{\prime} \mathrm{W}$ & 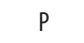 & WA \\
\hline Costa Rica, Emas National Park & $18^{\circ} 18^{\prime} \mathrm{S}$ & $52^{\circ} 57^{\prime} \mathrm{W}$ & $P, 0$ & WA, RSS \\
\hline Coxim, Fazenda Monte Verde & $18^{\circ} 15^{\prime} \mathrm{S}$ & $54^{\circ} 41^{\prime} \mathrm{W}$ & $s$ & MZUSP, MCZ, (Pinto, 1944) \\
\hline Coxim, Fazenda Recreio & $18^{\circ} 22^{\prime} \mathrm{S}$ & $54^{\circ} 46^{\prime} \mathrm{W}$ & $S$ & FMNH, (Pinto, 1944) \\
\hline Ribas do Rio Pardo & $20^{\circ} 27^{\prime} \mathrm{S}$ & $53^{\circ} 49^{\prime} \mathrm{W}$ & $P$ & WA \\
\hline Terenos & $20^{\circ} 25^{\prime} \mathrm{S}$ & $54^{\circ} 53^{\prime} \mathrm{W}$ & $\mathrm{P}, \mathrm{V}$ & $E B$, WA \\
\hline \multicolumn{5}{|l|}{ Minas Gerais } \\
\hline Aiuruoca & $21^{\circ} 47^{\prime} S$ & $44^{\circ} 42^{\prime} \mathrm{W}$ & $P$ & EB, WA, (Peixoto, 2014) \\
\hline Andrelândia & $21^{\circ} 44^{\prime} \mathrm{s}$ & $44^{\circ} 11^{\prime} \mathrm{W}$ & $\mathrm{P}$ & XC, WA, (Peixoto, 2014) \\
\hline Antônio Carlos & $21^{\circ} 18^{\prime} \mathrm{S}$ & $43^{\circ} 45^{\prime} \mathrm{W}$ & $\mathrm{p}$ & WA \\
\hline Antônio Carlos, São Sebastião de Campolide & $21^{\circ} 17^{\prime} \mathrm{S}$ & $43^{\circ} 50^{\prime} \mathrm{W}$ & $P$ & WA \\
\hline Araguari & $18^{\circ} 39^{\prime} \mathrm{S}$ & $48^{\circ} 11^{\prime} \mathrm{W}$ & $\mathrm{P}$ & WA \\
\hline Araxá, Horizonte Perdido & $19^{\circ} 42^{\prime} 5$ & $46^{\circ} 51^{\prime} \mathrm{W}$ & 0 & RSS \\
\hline Araxá, Ribeirão do Inferno & $19^{\circ} 46^{\prime} \mathrm{S}$ & $46^{\circ} 52^{\prime} \mathrm{W}$ & 0 & RSS \\
\hline
\end{tabular}




\begin{tabular}{|c|c|c|c|c|}
\hline Country, State/Province/Departament, Municipality, Locality & Latitude & Longitude & Record & Source \\
\hline Araxá, Serra da Bocaína & $19^{\circ} 43^{\prime} S$ & $46^{\circ} 48^{\prime} \mathrm{W}$ & P & WA \\
\hline Barbacena, Galego & $21^{\circ} 15^{\prime} S$ & $43^{\circ} 43^{\prime} \mathrm{W}$ & $P, V$ & WA \\
\hline Belo Vale, Serra de Belo Vale & $20^{\circ} 25^{\prime} \mathrm{S}$ & $43^{\circ} 56^{\prime} \mathrm{W}$ & V & WA, EB \\
\hline Bias Fortes, Várzea de Santo Antônio & $21^{\circ} 36^{\prime} S$ & $43^{\circ} 43^{\prime} \mathrm{W}$ & $P$ & WA \\
\hline Boa Esperança, Serra da Boa Esperança State Park & $20^{\circ} 58^{\prime} \mathrm{S}$ & $45^{\circ} 40^{\prime} \mathrm{W}$ & $P$ & $E B, W A$ \\
\hline Bom Jardim de Minas, Fazenda Areão & $21^{\circ} 52^{\prime} S$ & $44^{\circ} 07^{\prime} \mathrm{W}$ & 0 & (Pacheco et al., 2008), (Lopes et al., 2009) \\
\hline Brumadinho, Serra da Moeda & $20^{\circ} 05^{\prime} \mathrm{S}$ & $44^{\circ} 10^{\prime} \mathrm{W}$ & $P$ & WA \\
\hline Buenópolis, Serra do Cabral State Park & $17^{\circ} 51^{\prime} S$ & $44^{\circ} 15^{\prime} \mathrm{W}$ & $P$ & WA, RSS \\
\hline Campos Altos & $19^{\circ} 41^{\prime} S$ & $46^{\circ} 10^{\prime} \mathrm{W}$ & $P$ & WA \\
\hline Capitólio & $20^{\circ} 36^{\prime} \mathrm{S}$ & $46^{\circ} 04^{\prime} \mathrm{W}$ & V & WA \\
\hline Carmo da Cachoeira & $21^{\circ} 22^{\prime} S$ & $45^{\circ} 30^{\prime} \mathrm{W}$ & $P$ & WA \\
\hline Carrancas & $21^{\circ} 28^{\prime} S$ & $44^{\circ} 36^{\prime} \mathrm{W}$ & $P, V$ & WA, (Peixoto, 2014) \\
\hline Carrancas & $21^{\circ} 29^{\prime} S$ & $44^{\circ} 38^{\prime} \mathrm{W}$ & 0 & (Lombardi et al., 2012) \\
\hline Carrancas, Fazenda do Oswaldo & $21^{\circ} 30^{\prime} S$ & $44^{\circ} 52^{\prime} \mathrm{W}$ & $P$ & (Moura \& Corrêa, 2012) \\
\hline Carrancas, Serra das Broas & $21^{\circ} 36^{\prime} S$ & $44^{\circ} 36^{\prime} \mathrm{W}$ & $P$ & (Moura \& Corrêa, 2012), WA, RSS \\
\hline Carrancas, Serra de Carrancas & $21^{\circ} 26^{\prime} S$ & $44^{\circ} 42^{\prime} \mathrm{W}$ & $P$ & $E B, X C, W A, R S S$ \\
\hline Conceição do Mato Dentro, Parque Natural Municipal do Tabuleiro & $19^{\circ} 05^{\prime} S$ & $43^{\circ} 34^{\prime} \mathrm{W}$ & 0 & (IEF, 2016) \\
\hline Conceição do Mato Dentro, Parque Natural Municipal do Tabuleiro, headwaters of Ribeirão do Campo & $19^{\circ} 04^{\prime} S$ & $43^{\circ} 37^{\prime} \mathrm{W}$ & 0 & (IEF, 2016) \\
\hline Conceição do Mato Dentro, Serra do Intendente State Park, hedwaters of Rio Cubas & $19^{\circ} 07^{\prime} S$ & $43^{\circ} 33^{\prime} \mathrm{W}$ & 0 & (IEF, 2016) \\
\hline Conceição do Mato Dentro, Serra do Intendente State Park & $18^{\circ} 58^{\prime} S$ & $43^{\circ} 39^{\prime} \mathrm{W}$ & 0 & (IEF, 2016) \\
\hline Congonhas & $20^{\circ} 29^{\prime} S$ & $43^{\circ} 50^{\prime} \mathrm{W}$ & 0 & (Mazzoni et al., 2012) \\
\hline Coronel Xavier Chaves & $21^{\circ} 03^{\prime} S$ & $44^{\circ} 09^{\prime} \mathrm{W}$ & 0 & EB \\
\hline Cruzeiro da Fortaleza & $18^{\circ} 58^{\prime} S$ & $46^{\circ} 40^{\prime} \mathrm{W}$ & $P$ & WA \\
\hline Cruzília & $21^{\circ} 43^{\prime} S$ & $44^{\circ} 43^{\prime} \mathrm{W}$ & V & XC, (Peixoto, 2014) \\
\hline Curvelo & $18^{\circ} 44^{\prime} S$ & $44^{\circ} 26^{\prime} \mathrm{W}$ & $P$ & WA \\
\hline Curvelo, Fazenda Olhos D’Água & $19^{\circ} 00^{\prime} \mathrm{S}$ & $44^{\circ} 30^{\prime} \mathrm{W}$ & 0 & (Melo, 1997) \\
\hline Delfinópolis, Serra da Babilônia & $20^{\circ} 21^{\prime} \mathrm{S}$ & $46^{\circ} 34^{\prime} \mathrm{W}$ & $P$ & WA, RSS \\
\hline Diamantina, Guinda & $18^{\circ} 15^{\prime} S$ & $43^{\circ} 40^{\prime} \mathrm{W}$ & $P$ & WA \\
\hline Diamantina, Sempre-Vivas National Park & $17^{\circ} 48^{\prime} S$ & $43^{\circ} 46^{\prime} \mathrm{W}$ & $P$ & WA \\
\hline Estrela do Sul, Fazenda Monte Carmelo, Ribeirão Piçarrão & $18^{\circ} 48^{\prime} S$ & $47^{\circ} 53^{\prime} \mathrm{W}$ & 0 & (Lopes et al., 2009) \\
\hline Felixlândia & $18^{\circ} 45^{\prime} S$ & $44^{\circ} 52^{\prime} \mathrm{W}$ & P & WA \\
\hline Francisco Dumont, Serra do Cabral, Vereda Córrego do Cachorro & $17^{\circ} 23^{\prime} S$ & $44^{\circ} 15^{\prime} \mathrm{W}$ & P & WA \\
\hline Gouveia & $18^{\circ} 34^{\prime} S$ & $43^{\circ} 54^{\prime} \mathrm{W}$ & $P, V$ & WA \\
\hline Guapé, Serra da Rapadura/Serra dos Macacos & $20^{\circ} 50^{\prime} \mathrm{S}$ & $45^{\circ} 55^{\prime} \mathrm{W}$ & $P$ & WA \\
\hline Ibertioga & $21^{\circ} 24^{\prime} S$ & $43^{\circ} 56^{\prime} \mathrm{W}$ & $P$ & WA, (Peixoto, 2014) \\
\hline Ibiá & $19^{\circ} 29^{\prime} S$ & $46^{\circ} 32^{\prime} \mathrm{W}$ & $P$ & WA \\
\hline Indianópolis & $19^{\circ} 02^{\prime} \mathrm{S}$ & $47^{\circ} 55^{\prime} \mathrm{W}$ & $P$ & WA \\
\hline Indianópolis, Fazenda Monte Carmelo, Ribeirão Mandaguari & $19^{\circ} 02^{\prime} S$ & $47^{\circ} 42^{\prime} \mathrm{W}$ & 0 & EB, (Lopes et al., 2009) \\
\hline Indianópolis, Fazenda Nova Monte Carmelo & $18^{\circ} 55^{\prime} \mathrm{S}$ & $47^{\circ} 40^{\prime} \mathrm{W}$ & 0 & (Ferreira et al., 2015) \\
\hline Itabira, Serra dos Alves & $19^{\circ} 30^{\prime} \mathrm{S}$ & $43^{\circ} 27^{\prime} \mathrm{W}$ & $P, V$ & WA, EB \\
\hline Itabira, Mata do Limoeiro State Park & $19^{\circ} 35^{\prime} \mathrm{S}$ & $43^{\circ} 25^{\prime} \mathrm{W}$ & $P$ & WA \\
\hline Itabirito & $20^{\circ} 15^{\prime} \mathrm{S}$ & $43^{\circ} 53^{\prime} \mathrm{W}$ & $P$ & WA, EB \\
\hline Itajubá, near Frigorífico Frivasa & $22^{\circ} 26^{\prime} S$ & $45^{\circ} 27^{\prime} \mathrm{W}$ & $P$ & WA \\
\hline Itaverava & $20^{\circ} 39^{\prime} \mathrm{S}$ & $43^{\circ} 36^{\prime} \mathrm{W}$ & $P, V$ & WA \\
\hline Itutinga & $21^{\circ} 23^{\prime} S$ & $44^{\circ} 40^{\prime} \mathrm{W}$ & 0 & EB \\
\hline Jaboticatubas, Serra do Cipó National Park & $19^{\circ} 30^{\prime} \mathrm{S}$ & $43^{\circ} 36^{\prime} \mathrm{W}$ & $\mathrm{P}$ & WA \\
\hline Juiz de Fora, Paredão de Pedra, Condomínio do Sol & $21^{\circ} 45^{\prime} S$ & $43^{\circ} 21^{\prime} \mathrm{W}$ & $P$ & WA \\
\hline Juiz de Fora, Road of Torreões & $21^{\circ} 49^{\prime} S$ & $43^{\circ} 28^{\prime} \mathrm{W}$ & $P$ & WA \\
\hline Lavras, Quedas do Rio Bonito Ecological Park & $21^{\circ} 19^{\prime} S$ & $44^{\circ} 58^{\prime} \mathrm{W}$ & 0 & $E B$ \\
\hline Lavras, Serra do Carrapato & $21^{\circ} 20^{\prime} \mathrm{S}$ & $44^{\circ} 57^{\prime} \mathrm{W}$ & $P, V$ & $E B, W A$ \\
\hline Lima Duarte, Fazenda do Sr. G.C. Fonseca & $21^{\circ} 43^{\prime} S$ & $44^{\circ} 00^{\prime} \mathrm{W}$ & 0 & (Lopes et al., 2009) \\
\hline Lima Duarte, São Sebastião do Monte Verde & $21^{\circ} 55^{\prime} \mathrm{S}$ & $43^{\circ} 50^{\prime} \mathrm{W}$ & $P$ & WA \\
\hline Lima Duarte, Souza & $21^{\circ} 48^{\prime} S$ & $44^{\circ} 03^{\prime} \mathrm{W}$ & 0 & (Lopes et al., 2009) \\
\hline Luminárias, Serra Grande & $21^{\circ} 32^{\prime} S$ & $44^{\circ} 49^{\prime} \mathrm{W}$ & $P$ & EB, XC, WA, (Peixoto, 2014) \\
\hline Madre de Deus de Minas & $21^{\circ} 32^{\prime} S$ & $44^{\circ} 21^{\prime} \mathrm{W}$ & $P$ & WA, (Peixoto, 2014) \\
\hline Medeiros & $19^{\circ} 58^{\prime} S$ & $46^{\circ} 13^{\prime} \mathrm{W}$ & $P$ & WA \\
\hline Minduri & $21^{\circ} 40^{\prime} \mathrm{S}$ & $44^{\circ} 36^{\prime} \mathrm{W}$ & 0 & (Lombardi et al., 2012) \\
\hline Minduri, Serra da Chapada das Perdizes & $21^{\circ} 35^{\prime} \mathrm{S}$ & $44^{\circ} 35^{\prime} \mathrm{W}$ & 0 & WA, (Lombardi et al., 2012) \\
\hline Morro do Pilar, APA Morro da Pedreira & $19^{\circ} 17^{\prime} S$ & $42^{\circ} 39^{\prime} \mathrm{W}$ & $P$ & WA \\
\hline Morro do Pilar, RPPN Aves Gerais, headwaters of Rio Picão & $19^{\circ} 13^{\prime} S$ & $43^{\circ} 29^{\prime} \mathrm{W}$ & $P, V$ & (Carrara \& Faria, 2012) \\
\hline Morro do Pilar, Serra do Cipó National Park & $19^{\circ} 15^{\prime} S$ & $43^{\circ} 31^{\prime} \mathrm{W}$ & $P, V$ & WA, XC, (Rodrigues et al., 2011) \\
\hline Nepomuceno & $21^{\circ} 22^{\prime} S$ & $45^{\circ} 14^{\prime} \mathrm{W}$ & 0 & EB \\
\hline
\end{tabular}




\begin{tabular}{|c|c|c|c|c|}
\hline Country, State/Province/Departament, Municipality, Locality & Latitude & Longitude & Record & Source \\
\hline Nova Lima, Estrada de Rio de Peixe & $20^{\circ} 04^{\prime} \mathrm{S}$ & $43^{\circ} 54^{\prime} \mathrm{W}$ & $P$ & WA \\
\hline Nova Lima, Retiro das Pedras & $20^{\circ} 06^{\prime} \mathrm{S}$ & $43^{\circ} 59^{\prime} \mathrm{W}$ & $S, P, V$ & DZUFMG, MCNA, WA \\
\hline Nova Lima, São Sebastião das Águas Claras & $20^{\circ} 02^{\prime} \mathrm{S}$ & $43^{\circ} 57^{\prime} \mathrm{W}$ & $P$ & WA \\
\hline Nova Lima, Serra do Curral, RPPN Mata do Jambreiro & $19^{\circ} 58^{\prime} \mathrm{S}$ & $43^{\circ} 54^{\prime} \mathrm{W}$ & $P$ & WA \\
\hline Nova Lima, Serra do Rola Moça State Park & $20^{\circ} 03^{\prime} \mathrm{S}$ & $44^{\circ} 00^{\prime} \mathrm{W}$ & 0 & (Hoffmann et al., 2007) \\
\hline Nova Ponte & $19^{\circ} 09^{\prime} \mathrm{S}$ & $47^{\circ} 41^{\prime} \mathrm{W}$ & 0 & $E B$ \\
\hline Nova Ponte, Fazenda São Pedro & $18^{\circ} 55^{\prime} \mathrm{S}$ & $47^{\circ} 42^{\prime} \mathrm{W}$ & 0 & (SUPRAM, 2019) \\
\hline Olaria & $21^{\circ} 52^{\prime} \mathrm{S}$ & $43^{\circ} 55^{\prime} \mathrm{W}$ & $P$ & WA \\
\hline Ouro Preto, Miguel Burnier & $20^{\circ} 26^{\prime} \mathrm{S}$ & $43^{\circ} 47^{\prime} \mathrm{W}$ & $P, V$ & (Mazzoni et al., 2012) \\
\hline Paracatu, headwaters of Ribeirão Batalha & $17^{\circ} 29^{\prime} \mathrm{S}$ & $47^{\circ} 15^{\prime} \mathrm{W}$ & $P$ & RSS \\
\hline Patos de Minas, Mosaic Fertilizantes & $18^{\circ} 22^{\prime} \mathrm{S}$ & $46^{\circ} 54^{\prime} \mathrm{W}$ & $P$ & RSS \\
\hline Patrocínio, headwaters of Córrego Bebedouro, Mosaic Fertilizantes & $19^{\circ} 00^{\prime} \mathrm{S}$ & $46^{\circ} 46^{\prime} \mathrm{W}$ & $S, P$ & RSS, MZUSP \\
\hline Patrocínio, headwaters of Córrego Capoeira Grande & $19^{\circ} 11^{\prime} \mathrm{S}$ & $46^{\circ} 55^{\prime} \mathrm{W}$ & $\mathrm{S}, \mathrm{P}, \mathrm{V}$ & RSS, XC, MZUSP \\
\hline Patrocínio, headwaters of Córrego do Fundão & $19^{\circ} 05^{\prime} \mathrm{S}$ & $46^{\circ} 53^{\prime} \mathrm{W}$ & $S, P$ & MZUSP, RSS \\
\hline Patrocínio, headwaters of Córrego do Jacu & $19^{\circ} 03^{\prime} \mathrm{S}$ & $46^{\circ} 52^{\prime} \mathrm{W}$ & $P$ & RSS \\
\hline Patrocínio, headwaters of Córrego do Mato & $19^{\circ} 09^{\prime} \mathrm{S}$ & $46^{\circ} 55^{\prime} \mathrm{W}$ & $P$ & RSS \\
\hline Patrocínio, headwaters of Córrego Duas Pontes & $19^{\circ} 09^{\prime} \mathrm{S}$ & $46^{\circ} 56^{\prime} W$ & $P$ & RSS \\
\hline Patrocínio, near power line 1 & $19^{\circ} 04^{\prime} \mathrm{S}$ & $46^{\circ} 52^{\prime} W$ & $P$ & RSS \\
\hline Patrocínio, Serra Chapadão de Ferro & $18^{\circ} 55^{\prime} \mathrm{S}$ & $46^{\circ} 49^{\prime} \mathrm{W}$ & 0 & (Mattos et al., 1991), RSS \\
\hline Perdizes & $19^{\circ} 21^{\prime} \mathrm{S}$ & $47^{\circ} 16^{\prime} \mathrm{W}$ & $P, V$ & WA \\
\hline Perdizes, RPPN Unidade de Conservação de Galheiros & $19^{\circ} 12^{\prime} \mathrm{S}$ & $47^{\circ} 08^{\prime} \mathrm{W}$ & $0, V$ & (Malacco et al., 2003), (Lopes et al., 2009) \\
\hline Piedade do Rio Grande & $21^{\circ} 27^{\prime} \mathrm{S}$ & $44^{\circ} 11^{\prime} \mathrm{W}$ & $P, V$ & WA, XC \\
\hline Pimenta & $20^{\circ} 28^{\prime} S$ & $45^{\circ} 48^{\prime} \mathrm{W}$ & $P$ & WA \\
\hline Piranguinho & $22^{\circ} 24^{\prime} \mathrm{S}$ & $45^{\circ} 32^{\prime} \mathrm{W}$ & $P$ & WA \\
\hline Piranguinho, Olegário Maciel & $22^{\circ} 19^{\prime} S$ & $45^{\circ} 35^{\prime} \mathrm{W}$ & 0 & (Mattos et al., 1991) \\
\hline Piumhi, Serra de Piumhi & $20^{\circ} 28^{\prime} \mathrm{S}$ & $45^{\circ} 55^{\prime} \mathrm{W}$ & $P$ & WA \\
\hline Pompéu & $19^{\circ} 10^{\prime} \mathrm{S}$ & $45^{\circ} 02^{\prime} \mathrm{W}$ & $P, V$ & WA, (Souza et al., 2018) \\
\hline Pouso Alegre & $22^{\circ} 07^{\prime} \mathrm{S}$ & $45^{\circ} 51^{\prime} \mathrm{W}$ & $P, V$ & $W A, E B$ \\
\hline Prados, Pitangueiras & $21^{\circ} 12^{\prime} \mathrm{S}$ & $44^{\circ} 04^{\prime} \mathrm{W}$ & $P$ & WA \\
\hline Prados, Ribeirão do Elvas & $21^{\circ} 08^{\prime} S$ & $44^{\circ} 06^{\prime} \mathrm{W}$ & $P$ & WA \\
\hline Quartel Geral, Quartel São João & $19^{\circ} 15^{\prime} \mathrm{S}$ & $45^{\circ} 47^{\prime} \mathrm{W}$ & $P, V$ & (Moura et al., 2011) \\
\hline Resende Costa, Córrego da Cruz & $20^{\circ} 54^{\prime} \mathrm{S}$ & $44^{\circ} 15^{\prime} \mathrm{W}$ & $P, V$ & $W A, E B$ \\
\hline Sacramento, Serra da Canastra National Park & $20^{\circ} 08^{\prime} \mathrm{S}$ & $46^{\circ} 51^{\prime} \mathrm{W}$ & $P$ & RSS, WA \\
\hline Santa Bárbara do Monte Verde & $21^{\circ} 56^{\prime} \mathrm{S}$ & $43^{\circ} 42^{\prime} \mathrm{W}$ & P & WA \\
\hline Santa Rita de Ibitipoca & $21^{\circ} 33^{\prime} S$ & $43^{\circ} 55^{\prime} \mathrm{W}$ & V & $X C$ \\
\hline Santa Rita do Sapucaí & $21^{\circ} 12^{\prime} S$ & $45^{\circ} 42^{\prime} W$ & 0 & $E B$ \\
\hline Santa Vitória, São Simão Channel, Serra Negra & $18^{\circ} 56^{\prime} \mathrm{S}$ & $50^{\circ} 30^{\prime} \mathrm{W}$ & 0 & (Mattos et al., 1991) \\
\hline Santana do Garambéu & $21^{\circ} 34^{\prime} \mathrm{S}$ & $44^{\circ} 04^{\prime} \mathrm{W}$ & $P, V$ & WA, XC \\
\hline Santana do Garambéu, Fazenda do Sr. Pp.S. Almeida & $21^{\circ} 43^{\prime} \mathrm{S}$ & $44^{\circ} 05^{\prime} \mathrm{W}$ & 0 & (Lopes et al., 2009) \\
\hline Santana do Riacho, Lapinha da Serra, Serra do Cipó & $19^{\circ} 07^{\prime} \mathrm{S}$ & $43^{\circ} 40^{\prime} \mathrm{W}$ & $P$ & WA, EB \\
\hline Santana do Riacho, Cardeal Mota, Serra do Cipó & $19^{\circ} 19^{\prime} \mathrm{S}$ & $43^{\circ} 37^{\prime} \mathrm{W}$ & $P$ & WA \\
\hline Santana dos Montes & $20^{\circ} 47^{\prime} \mathrm{S}$ & $43^{\circ} 41^{\prime} \mathrm{W}$ & P & WA, EB \\
\hline Santo Hilário & $20^{\circ} 39^{\prime} \mathrm{S}$ & $45^{\circ} 50^{\prime} \mathrm{W}$ & 0 & $\mathrm{~EB}$ \\
\hline São Gonçalo do Abaeté, Fazenda São Francisco 4 and 10 & $18^{\circ} 18^{\prime} S$ & $45^{\circ} 48^{\prime} \mathrm{W}$ & $P, V$ & WA \\
\hline São João Batista do Glória, Serra da Canastra National Park & $20^{\circ} 32^{\prime} S$ & $46^{\circ} 24^{\prime} \mathrm{W}$ & $P$ & WA, EB \\
\hline São João del Rei & $21^{\circ} 15^{\prime} \mathrm{S}$ & $44^{\circ} 20^{\prime} \mathrm{W}$ & $P, V$ & WA, (Peixoto, 2014) \\
\hline São João del Rei & $21^{\circ} 16^{\prime} S$ & $44^{\circ} 08^{\prime} W$ & 0 & (Peixoto, 2014), RSS \\
\hline São João del Rei & $21^{\circ} 16^{\prime} S$ & $44^{\circ} 04^{\prime} \mathrm{W}$ & 0 & (Peixoto, 2014) \\
\hline São João del Rei, Serra do Carvoeiro & $21^{\circ} 09^{\prime} \mathrm{S}$ & $44^{\circ} 11^{\prime} \mathrm{W}$ & $P$ & $E B$ \\
\hline São Roque de Minas, Serra da Canastra National Park & $20^{\circ} 14^{\prime} \mathrm{S}$ & $46^{\circ} 32^{\prime} W$ & $P, V$ & (Silveira, 1998), EB, ML, WA, XC, RSS \\
\hline São Thomé das Letras & $21^{\circ} 43^{\prime} \mathrm{S}$ & $44^{\circ} 58^{\prime} \mathrm{W}$ & $P$ & WA \\
\hline São Tiago & $20^{\circ} 54^{\prime} \mathrm{S}$ & $44^{\circ} 30^{\prime} \mathrm{W}$ & $P$ & WA \\
\hline São Vicente de Minas, Fazenda Bom Jardim & $21^{\circ} 38^{\prime} S$ & $44^{\circ} 25^{\prime} \mathrm{W}$ & $P$ & $E B, W A$ \\
\hline Sete Lagoas, Serra de Santa Helena & $19^{\circ} 26^{\prime} S$ & $44^{\circ} 16^{\prime} \mathrm{W}$ & $P$ & WA \\
\hline Tapira, Mosaic Fertilizantes (BD-5) & $19^{\circ} 49^{\prime} \mathrm{S}$ & $46^{\circ} 50^{\prime} \mathrm{W}$ & $P, V$ & RSS, XC \\
\hline Tapira, Mosaic Fertilizantes (Natural Reserve) & $19^{\circ} 51^{\prime} \mathrm{S}$ & $46^{\circ} 47^{\prime} \mathrm{W}$ & P & RSS \\
\hline Tapira, Ribeirão do Inferno & $19^{\circ} 47^{\prime} \mathrm{S}$ & $46^{\circ} 53^{\prime} \mathrm{W}$ & $P$ & RSS \\
\hline Três Marias, Fazenda Araras 8 & $18^{\circ} 11^{\prime} S$ & $45^{\circ} 06^{\prime} \mathrm{W}$ & $P$ & WA \\
\hline Três Marias, Fazenda Perdões & $18^{\circ} 11^{\prime} \mathrm{S}$ & $45^{\circ} 25^{\prime} \mathrm{W}$ & 0 & (Ribon et al., 1995) \\
\hline Uberaba, headwaters of Rio Uberabinha & $19^{\circ} 21^{\prime} \mathrm{S}$ & $47^{\circ} 54^{\prime} \mathrm{W}$ & $P$ & WA, EB \\
\hline Uberaba, Fazenda Água Emendada & $19^{\circ} 17^{\prime} \mathrm{S}$ & $48^{\circ} 01^{\prime} \mathrm{W}$ & 0 & (Lopes et al., 2009) \\
\hline Uberaba, RPPN Vale Encantado & $19^{\circ} 32^{\prime} S$ & $47^{\circ} 53^{\prime} \mathrm{W}$ & $\mathrm{P}$ & WA \\
\hline
\end{tabular}




\begin{tabular}{|c|c|c|c|c|}
\hline Country, State/Province/Departament, Municipality, Locality & Latitude & Longitude & Record & Source \\
\hline Unaí, Santuário da Vida Silvestre São Miguel, Fazenda São Miguel & $15^{\circ} 50^{\prime} \mathrm{S}$ & $46^{\circ} 30^{\prime} \mathrm{W}$ & 0 & (FUNATURA, 1994), (Lopes et al., 2008) \\
\hline Uruana de Minas, Cercado & $16^{\circ} 17^{\prime} S$ & $46^{\circ} 15^{\prime} \mathrm{W}$ & $\mathrm{P}$ & WA \\
\hline Vargem Bonita & $20^{\circ} 19^{\prime} S$ & $46^{\circ} 22^{\prime} \mathrm{W}$ & $\mathrm{P}$ & WA \\
\hline \multicolumn{5}{|l|}{ São Paulo } \\
\hline Águas de Santa Bárbara, Fazenda Experimental Santa Bárbara do Rio Pardo & $22^{\circ} 53^{\prime} S$ & $49^{\circ} 15^{\prime} \mathrm{W}$ & 0 & (Willis \& Oniki, 2003) \\
\hline Águas de Santa Bárbara, Santa Bárbara Ecological Station & $22^{\circ} 48^{\prime} S$ & $49^{\circ} 14^{\prime} \mathrm{W}$ & 0 & (Willis \& Oniki, 2003) \\
\hline Batatais & $20^{\circ} 53^{\prime} \mathrm{S}$ & $47^{\circ} 37^{\prime} \mathrm{W}$ & $S$ & MZUSP, (Pinto, 1944) \\
\hline Bofete & $23^{\circ} 05^{\prime} S$ & $48^{\circ} 16^{\prime} \mathrm{W}$ & $P$ & $W A, E B$ \\
\hline Botucatu, Botucatu State Forest & $22^{\circ} 56^{\prime} S$ & $48^{\circ} 27^{\prime} \mathrm{W}$ & $P, V$ & WA, EB, XC \\
\hline Botucatu, Sítio São José & $22^{\circ} 56^{\prime} \mathrm{S}$ & $48^{\circ} 25^{\prime} \mathrm{W}$ & $P$ & WA \\
\hline Broa, Rio Itaqueri & $22^{\circ} 15^{\prime} S$ & $47^{\circ} 52^{\prime} \mathrm{W}$ & 0 & (Willis \& Oniki, 2003) \\
\hline Castilho, RPPN Foz do Rio Aguapeí & $21^{\circ} 06^{\prime} \mathrm{S}$ & $51^{\circ} 44^{\prime} \mathrm{W}$ & 0 & (Miyaji, 2013) \\
\hline Franca & $20^{\circ} 32^{\prime} \mathrm{S}$ & $47^{\circ} 24^{\prime} \mathrm{W}$ & $S$ & MZUSP, (Pinto, 1944) \\
\hline Iperó, Ipanema & $23^{\circ} 26^{\prime} S$ & $47^{\circ} 36^{\prime} \mathrm{W}$ & $S$ & SMF, NMW \\
\hline Itapetininga, Fazenda Campo Grande & $23^{\circ} 38^{\prime} S$ & $47^{\circ} 58^{\prime} \mathrm{W}$ & 0 & (Willis \& Oniki, 2003) \\
\hline Itararé & $24^{\circ} 06^{\prime} S$ & $49^{\circ} 18^{\prime} \mathrm{W}$ & $S$ & NMW, NHMUK, RMNH \\
\hline Itararé, Fazenda Santa Andrea & $24^{\circ} 08^{\prime} \mathrm{S}$ & $49^{\circ} 10^{\prime} \mathrm{W}$ & 0 & (Willis \& Oniki, 2003) \\
\hline Itararé, Unidade de Pesquisa e Desenvolvimento de Itararé & $24^{\circ} 16^{\prime} S$ & $49^{\circ} 13^{\prime} \mathrm{W}$ & $S$ & MCP \\
\hline Itirapina, Itirapina Ecological Station & $22^{\circ} 13^{\prime} S$ & $47^{\circ} 54^{\prime} \mathrm{W}$ & $\mathrm{P}, \mathrm{V}$ & (Willis \& Oniki, 2003), WA \\
\hline Ituverava, Rio das Pedras & $20^{\circ} 11^{\prime} \mathrm{S}$ & $47^{\circ} 56^{\prime} \mathrm{W}$ & $S$ & NMW \\
\hline Santa Lúcia & $21^{\circ} 41^{\prime} S$ & $48^{\circ} 04^{\prime} \mathrm{W}$ & $S$ & $Z M B$ \\
\hline São Carlos, Fazenda Santa Maria da Fábrica & $22^{\circ} 10^{\prime} S$ & $47^{\circ} 55^{\prime} \mathrm{W}$ & 0 & (Willis \& Oniki, 2003) \\
\hline Taquarivaí, Córrego Escaramuça (Scaramuza) & $23^{\circ} 53^{\prime} \mathrm{S}$ & $48^{\circ} 46^{\prime} \mathrm{W}$ & $S$ & NMW \\
\hline \multicolumn{5}{|l|}{ Paraná } \\
\hline Balsa Nova, São Luiz do Purunã & $25^{\circ} 28^{\prime} \mathrm{S}$ & $49^{\circ} 42^{\prime} \mathrm{W}$ & $P, V$ & $W A, E B, X C$ \\
\hline Campo Largo & $25^{\circ} 27^{\prime} S$ & $49^{\circ} 29^{\prime} \mathrm{W}$ & $P$ & WA \\
\hline Candói, Fazenda Rodeio Velho & $25^{\circ} 38^{\prime} \mathrm{S}$ & $52^{\circ} 07^{\prime} \mathrm{W}$ & $\mathrm{P}, \mathrm{V}$ & WA, EB \\
\hline Castro & $24^{\circ} 46^{\prime} S$ & $49^{\circ} 59^{\prime} \mathrm{W}$ & $P$ & WA \\
\hline Curitiba & $25^{\circ} 27^{\prime} \mathrm{S}$ & $49^{\circ} 08^{\prime} \mathrm{W}$ & $S, V$ & NMW, NHMUK, XC \\
\hline Jaguariaíva & $24^{\circ} 15^{\prime} \mathrm{S}$ & $49^{\circ} 42^{\prime} \mathrm{W}$ & $0, P, V$ & (Santos, 2007), WA, EB \\
\hline Maringá, Campus do Centro Universitário de Maringá (CESUMAR) & $23^{\circ} 26^{\prime} S$ & $51^{\circ} 55^{\prime} \mathrm{W}$ & 0 & (Esclarski et al., 2011) \\
\hline Palmeira, Fazenda Santa Rita & $28^{\circ} 18^{\prime} S$ & $49^{\circ} 48^{\prime} \mathrm{W}$ & 0 & (Anjos \& Graf, 1993) \\
\hline Piraí do Sul, Fazenda Cuiabá & $24^{\circ} 24^{\prime} S$ & $50^{\circ} 02^{\prime} \mathrm{W}$ & $S, P$ & MCP,WA \\
\hline Piraquara & $25^{\circ} 26^{\prime} S$ & $49^{\circ} 04^{\prime} \mathrm{W}$ & $P, V$ & WA \\
\hline Ponta Grossa, Vila Velha State Park & $25^{\circ} 14^{\prime} S$ & $50^{\circ} 00^{\prime} \mathrm{W}$ & 0 & (Mikich \& Bérnils, 2004) \\
\hline Porto Amazonas & $25^{\circ} 32^{\prime} \mathrm{S}$ & $49^{\circ} 53^{\prime} \mathrm{W}$ & $\mathrm{P}$ & WA \\
\hline Quatro Barras, APA Estadual do Rio Iraí & $25^{\circ} 23^{\prime} \mathrm{S}$ & $49^{\circ} 04^{\prime} \mathrm{W}$ & $S$ & MHNCl, (Mikich \& Bérnils, 2004) \\
\hline São José dos Pinhais, Banhados do Rio Miringuava & $25^{\circ} 35^{\prime} \mathrm{S}$ & $49^{\circ} 10^{\prime} \mathrm{W}$ & $\mathrm{P}$ & WA \\
\hline São José dos Pinhais, Várzea na estrada do Curralinho & $25^{\circ} 33^{\prime} S$ & $49^{\circ} 03^{\prime} \mathrm{W}$ & $P$ & $E B$ \\
\hline Telêmaco Borba, Fazenda Monte Alegre & $24^{\circ} 12^{\prime} S$ & $50^{\circ} 33^{\prime} \mathrm{W}$ & 0 & (Rocha et al., 2003) \\
\hline Tibagi, Guartelá State Park & $24^{\circ} 40^{\prime} S$ & $50^{\circ} 13^{\prime} \mathrm{W}$ & $P, V$ & $E B, W A$ \\
\hline \multicolumn{5}{|l|}{ Santa Catarina } \\
\hline Campo Belo do Sul & $27^{\circ} 55^{\prime} \mathrm{S}$ & $50^{\circ} 47^{\prime} \mathrm{W}$ & $P, V$ & $E B, W A$ \\
\hline Capão Alto, Fazenda Pai João & $28^{\circ} 10^{\prime} S$ & $50^{\circ} 38^{\prime} \mathrm{W}$ & $P, V$ & WA, RSS \\
\hline Lages, Coxilha Rica & $28^{\circ} 17^{\prime} S$ & $50^{\circ} 17^{\prime} \mathrm{W}$ & $S, P, V$ & MCP, (Repenning et al., 2010) \\
\hline Lages, Coxilha Rica & $28^{\circ} 18^{\prime} S$ & $50^{\circ} 16^{\prime} \mathrm{W}$ & $S, P, V$ & MCP, (Repenning et al., 2010) \\
\hline Lages, Fazenda Santa Maria, Coxilha Rica & $28^{\circ} 15^{\prime} \mathrm{S}$ & $50^{\circ} 18^{\prime} \mathrm{W}$ & $P, V$ & (Repenning et al., 2010) \\
\hline Lages, Morrinhos, Coxilha Rica & $28^{\circ} 16^{\prime} S$ & $50^{\circ} 17^{\prime} \mathrm{W}$ & $\mathrm{P}$ & WA \\
\hline Lages, Rio Lava-Tudo Valley, Coxilha Rica & $28^{\circ} 18^{\prime} \mathrm{S}$ & $50^{\circ} 14^{\prime} \mathrm{W}$ & $\mathrm{P}$ & WA \\
\hline Urupema, Morro do Combate & $28^{\circ} 00^{\prime} S$ & $49^{\circ} 49^{\prime} \mathrm{W}$ & 0 & RSS \\
\hline \multicolumn{5}{|l|}{ Rio Grande do Sul } \\
\hline Alegrete, Fazenda Cerro dos Porongos & $30^{\circ} 04^{\prime} \mathrm{S}$ & $55^{\circ} 31^{\prime} \mathrm{W}$ & 0 & $E B$ \\
\hline Alegrete, Fazenda do Beto & $29^{\circ} 54^{\prime} \mathrm{S}$ & $55^{\circ} 49^{\prime} \mathrm{W}$ & 0 & (Fontana et al., 2003) \\
\hline Alegrete, Fazenda Sá Brito & $29^{\circ} 58^{\prime} \mathrm{S}$ & $55^{\circ} 45^{\prime} \mathrm{W}$ & 0 & $\mathrm{~EB}$ \\
\hline Alegrete. Ibirapuitã APA & $29^{\circ} 59^{\prime} S$ & $55^{\circ} 40^{\prime} \mathrm{W}$ & 0 & $E B$ \\
\hline Alegrete, Ibirapuitã Biological Reserve & $29^{\circ} 55^{\prime} \mathrm{S}$ & $55^{\circ} 47^{\prime} \mathrm{W}$ & V & (Bencke, 2001) \\
\hline Alegrete, Serra do Caverá & $30^{\circ} 23^{\prime} \mathrm{S}$ & $55^{\circ} 24^{\prime} \mathrm{W}$ & $P$ & WA \\
\hline Bom Jesus & $28^{\circ} 42^{\prime} \mathrm{S}$ & $50^{\circ} 24^{\prime} \mathrm{W}$ & $S, P, V$ & $M C P, X C, W A$ \\
\hline Bom Jesus, Arroio Água Branca & $28^{\circ} 35^{\prime} \mathrm{S}$ & $50^{\circ} 24^{\prime} \mathrm{W}$ & $S, P, V$ & MCP, (Repenning et al., 2010) \\
\hline Bom Jesus, Banhado do Arroio Água Branca & $28^{\circ} 36^{\prime} S$ & $50^{\circ} 23^{\prime} \mathrm{W}$ & $S, V$ & $M C P, E B$ \\
\hline Bom Jesus, Cachoeira dos Baggio & $28^{\circ} 40^{\prime} \mathrm{S}$ & $50^{\circ} 28^{\prime} \mathrm{W}$ & $P, V$ & (Repenning et al., 2010) \\
\hline Bom Jesus, Fazenda da Ronda & $28^{\circ} 28^{\prime} \mathrm{S}$ & $50^{\circ} 42^{\prime} \mathrm{W}$ & $P, V$ & (Repenning et al., 2010) \\
\hline
\end{tabular}




\begin{tabular}{|c|c|c|c|c|}
\hline Country, State/Province/Departament, Municipality, Locality & Latitude & Longitude & Record & Source \\
\hline Bom Jesus, northeast of Rio Santana & $28^{\circ} 26^{\prime} S$ & $50^{\circ} 41^{\prime} \mathrm{W}$ & $P, V$ & (Repenning et al., 2010) \\
\hline Bom Jesus, Road RS-110 & $28^{\circ} 35^{\prime} \mathrm{S}$ & $50^{\circ} 22^{\prime} \mathrm{W}$ & $P, V$ & (Repenning et al., 2010) \\
\hline Bom Jesus, Sanga José Luis & $28^{\circ} 28^{\prime} S$ & $50^{\circ} 42^{\prime} \mathrm{W}$ & $P, V$ & (Repenning et al., 2010) \\
\hline Bom Jesus, Várzea do Rio Santana & $28^{\circ} 29^{\prime} \mathrm{S}$ & $50^{\circ} 43^{\prime} \mathrm{W}$ & $P, V$ & (Repenning et al., 2010) \\
\hline Campestre da Serra, Guacho & $28^{\circ} 40^{\prime} \mathrm{S}$ & $51^{\circ} 05^{\prime} \mathrm{W}$ & $P$ & (Repenning et al., 2010), WA \\
\hline Cruz Alta & $28^{\circ} 36^{\prime} \mathrm{S}$ & $53^{\circ} 34^{\prime} \mathrm{W}$ & $P, V$ & WA \\
\hline Manoel Viana, Assentamento Santa Maria do Ibicuí & $29^{\circ} 29^{\prime} S$ & $55^{\circ} 37^{\prime} \mathrm{W}$ & 0 & $E B$ \\
\hline Rosário do Sul & $30^{\circ} 11^{\prime} \mathrm{S}$ & $54^{\circ} 57^{\prime} \mathrm{W}$ & $P$ & WA \\
\hline Rosário do Sul, Fazenda Schütz & $30^{\circ} 18^{\prime} \mathrm{S}$ & $54^{\circ} 51^{\prime} \mathrm{W}$ & 0 & EB \\
\hline Rosário do Sul, São Bento & $30^{\circ} 17^{\prime} \mathrm{S}$ & $54^{\circ} 46^{\prime} \mathrm{W}$ & 0 & EB \\
\hline Rosário do Sul, Vila Temp & $30^{\circ} 14^{\prime} \mathrm{S}$ & $54^{\circ} 51^{\prime} \mathrm{W}$ & 0 & $E B$ \\
\hline Santa Margarida do Sul & $30^{\circ} 21^{\prime} \mathrm{S}$ & $54^{\circ} 04^{\prime} \mathrm{W}$ & $P$ & WA \\
\hline Santa Maria & $29^{\circ} 44^{\prime} S$ & $53^{\circ} 50^{\prime} \mathrm{W}$ & $P$ & WA \\
\hline São Francisco de Assis & $29^{\circ} 36^{\prime} S$ & $54^{\circ} 45^{\prime} \mathrm{W}$ & 0 & (Gressler \& Krüger, 2005) \\
\hline São Francisco de Paula & $29^{\circ} 09^{\prime} S$ & $50^{\circ} 24^{\prime} \mathrm{W}$ & 0 & $E B$ \\
\hline São Gabriel & $30^{\circ} 23^{\prime} S$ & $54^{\circ} 21^{\prime} \mathrm{W}$ & $\mathrm{P}$ & $E B, W A$ \\
\hline São Gabriel, Suspiro & $30^{\circ} 37^{\prime} \mathrm{S}$ & $54^{\circ} 20^{\prime} \mathrm{W}$ & $P$ & $E B, W A$ \\
\hline São Gabriel, Horto Florestal Formosa (CMPC) & $30^{\circ} 17^{\prime} S$ & $54^{\circ} 47^{\prime} \mathrm{W}$ & $P$ & WA \\
\hline Tupanciretã, Porteira Encantada - Fazenda Moresco & $28^{\circ} 57^{\prime} \mathrm{S}$ & $53^{\circ} 46^{\prime} \mathrm{W}$ & $P$ & WA \\
\hline Tupanciretã, old Road Tupã-Cruz Alta & $28^{\circ} 56^{\prime} \mathrm{S}$ & $53^{\circ} 45^{\prime} \mathrm{W}$ & $P, V$ & $\mathrm{~EB}, \mathrm{WA}$ \\
\hline Vacaria, Arroio Pessegueiro & $28^{\circ} 22^{\prime} S$ & $50^{\circ} 45^{\prime} \mathrm{W}$ & $P, V$ & (Repenning et al., 2010) \\
\hline Vacaria, Banhado Rio Santana & $28^{\circ} 28^{\prime} S$ & $50^{\circ} 42^{\prime} \mathrm{W}$ & 0 & $E B$ \\
\hline Vacaria, Capão Alto & $28^{\circ} 12^{\prime} S$ & $51^{\circ} 00^{\prime} \mathrm{W}$ & $P, V$ & (Repenning et al., 2010) \\
\hline Vacaria, East of Rio Socorro & $28^{\circ} 21^{\prime} S$ & $50^{\circ} 53^{\prime} \mathrm{W}$ & $P, V$ & (Repenning et al., 2010) \\
\hline Vacaria, Estrada de Ferro & $28^{\circ} 21^{\prime} \mathrm{S}$ & $50^{\circ} 46^{\prime} \mathrm{W}$ & $P, V$ & (Repenning et al., 2010) \\
\hline Vacaria, Estrada de Ferro, Fazenda Socorro & $28^{\circ} 21^{\prime} S$ & $50^{\circ} 47^{\prime} \mathrm{W}$ & $P, V$ & (Repenning et al., 2010) \\
\hline Vacaria, headwaters of Arroio Macena & $28^{\circ} 30^{\prime} \mathrm{S}$ & $50^{\circ} 47^{\prime} \mathrm{W}$ & $P, V$ & (Repenning et al., 2010), WA \\
\hline Vacaria, Itacolomi & $28^{\circ} 13^{\prime} S$ & $50^{\circ} 52^{\prime} \mathrm{W}$ & $P, V$ & (Repenning et al., 2010) \\
\hline Vacaria, São Pedro, Capela do Caravaggio & $28^{\circ} 08^{\prime} S$ & $50^{\circ} 54^{\prime} \mathrm{W}$ & $S, P, V$ & MCP, (Repenning et al., 2010) \\
\hline Vacaria, Túneis da Estrada de Ferro & $28^{\circ} 19^{\prime} S$ & $50^{\circ} 43^{\prime} \mathrm{W}$ & $P, V$ & (Repenning et al., 2010) \\
\hline Vacaria, West of Rio Socorro & $28^{\circ} 20^{\prime} \mathrm{S}$ & $50^{\circ} 55^{\prime} \mathrm{W}$ & $P, V$ & (Repenning et al., 2010) \\
\hline Vacaria, Várzea do Arroio Moema & $28^{\circ} 30^{\prime} \mathrm{S}$ & $50^{\circ} 48^{\prime} \mathrm{W}$ & $S$ & MCP \\
\hline \multicolumn{5}{|l|}{ BOLIVIA } \\
\hline \multicolumn{5}{|l|}{ La Paz } \\
\hline $7 \mathrm{~km}$ East of Ixiamas & $13^{\circ} 46^{\prime} \mathrm{S}$ & $68^{\circ} 03^{\prime} \mathrm{W}$ & 0 & (Parker III et al., 1991) \\
\hline Franz Tamayo, Apolo, Madidi Savanna, Madidi National Park & $14^{\circ} 43^{\prime} \mathrm{S}$ & $68^{\circ} 21^{\prime} \mathrm{W}$ & V & (Soria-Auza \& Hennessey, 2005), ML \\
\hline Ixiamas & $13^{\circ} 45^{\prime} \mathrm{S}$ & $68^{\circ} 05^{\prime} \mathrm{W}$ & 0 & $E B$ \\
\hline Pampa Moscoso & $13^{\circ} 02^{\prime} \mathrm{S}$ & $68^{\circ} 50^{\prime} \mathrm{W}$ & 0 & $E B$ \\
\hline \multicolumn{5}{|l|}{ El Beni } \\
\hline 10 km Southwest of San Borja & $14^{\circ} 53^{\prime} S$ & $66^{\circ} 51^{\prime} W$ & 0 & (Parker III et al., 1991) \\
\hline 26 and $30 \mathrm{~km}$ East of San Borja & $14^{\circ} 49^{\prime} S$ & $66^{\circ} 51^{\prime} \mathrm{W}$ & V & (Parker III et al., 1991), ML \\
\hline Barba Azul Nature Reserve & $13^{\circ} 45^{\prime} S$ & $66^{\circ} 05^{\prime} \mathrm{W}$ & $P$ & $E B$ \\
\hline Beni Biosphere Station & $14^{\circ} 38^{\prime} S$ & $66^{\circ} 17^{\prime} \mathrm{W}$ & 0 & $E B$ \\
\hline Cerro San Simón & $13^{\circ} 36^{\prime} S$ & $62^{\circ} 15^{\prime} \mathrm{W}$ & 0 & (Parker III \& Rocha, 1991) \\
\hline Estancia El Porvenir, Beni Biological Station & $14^{\circ} 50^{\prime} \mathrm{S}$ & $66^{\circ} 17^{\prime} \mathrm{W}$ & 0 & (Brace et al., 1997) \\
\hline Estancia Motacuzal & $13^{\circ} 45^{\prime} S$ & $64^{\circ} 37^{\prime} \mathrm{W}$ & 0 & EB \\
\hline Estancia Peñas Verdes & $13^{\circ} 36^{\prime} S$ & $64^{\circ} 30^{\prime} \mathrm{W}$ & 0 & $E B$ \\
\hline General Jose Ballivan, 3 km Southwest of San Borja & $14^{\circ} 51^{\prime} \mathrm{S}$ & $66^{\circ} 50^{\prime} \mathrm{W}$ & $S$ & LSUMZ, (Schmitt \& Schmitt, 1987) \\
\hline Las Palmiras & $13^{\circ} 44^{\prime} \mathrm{S}$ & $66^{\circ} 24^{\prime} W$ & 0 & $E B$ \\
\hline Llanos de Mojos, 7 Islas Camp & $13^{\circ} 48^{\prime} \mathrm{S}$ & $64^{\circ} 30^{\prime} \mathrm{W}$ & 0 & $E B$ \\
\hline North of Trinidad & $13^{\circ} 37^{\prime} \mathrm{S}$ & $64^{\circ} 58^{\prime} \mathrm{W}$ & 0 & (Soria-Auza \& Hennessey, 2005) \\
\hline Puerto Ustarez & $12^{\circ} 44^{\prime} \mathrm{S}$ & $64^{\circ} 38^{\prime} \mathrm{W}$ & $P$ & $E B$ \\
\hline Selva Blue, Laguna Larga & $12^{\circ} 49^{\prime} \mathrm{S}$ & $65^{\circ} 46^{\prime} W$ & 0 & $E B$ \\
\hline Upper Yata/Tapado & $13^{\circ} 16^{\prime} S$ & $66^{\circ} 02^{\prime} \mathrm{W}$ & 0 & $E B$ \\
\hline \multicolumn{5}{|l|}{ Santa Cruz } \\
\hline Buena Vista & $17^{\circ} 27^{\prime} S$ & $63^{\circ} 40^{\prime} \mathrm{W}$ & $S$ & ANSP, CM \\
\hline Santa Rosa de la Roca & $15^{\circ} 54^{\prime} \mathrm{S}$ & $61^{\circ} 24^{\prime} \mathrm{W}$ & $P$ & EB \\
\hline Serranía de Huanchaca I, Noel Kempff Mercado National Park & $13^{\circ} 57^{\prime} \mathrm{S}$ & $60^{\circ} 49^{\prime} \mathrm{W}$ & $S$ & LSUMZ, (Bates \& Parker III, 1998) \\
\hline Serranía de Huanchaca II, Noel Kempff Mercado National Park & $14^{\circ} 31^{\prime} S$ & $60^{\circ} 44^{\prime} \mathrm{W}$ & $S$ & LSUMZ, MNK, (Bates \& Parker III, 1998), EB \\
\hline \multicolumn{5}{|l|}{ PARAGUAY } \\
\hline \multicolumn{5}{|l|}{ San Pedro } \\
\hline Establecimiento Laguna Blanca, Retiro Malvina & $23^{\circ} 49^{\prime} \mathrm{S}$ & $56^{\circ} 18^{\prime} W$ & 0 & (Barnett et al., 2004) \\
\hline
\end{tabular}




\begin{tabular}{|c|c|c|c|c|}
\hline Country, State/Province/Departament, Municipality, Locality & Latitude & Longitude & Record & Source \\
\hline Estancia Villa Josefina & $23^{\circ} 55^{\prime} \mathrm{S}$ & $56^{\circ} 45^{\prime} \mathrm{W}$ & 0 & $E B$ \\
\hline Forestadora Río Verde & $23^{\circ} 46^{\prime} S$ & $56^{\circ} 20^{\prime} \mathrm{W}$ & $\mathrm{P}$ & $E B$ \\
\hline Laguna Blanca & $23^{\circ} 46^{\prime} \mathrm{S}$ & $56^{\circ} 17^{\prime} \mathrm{W}$ & $P$ & (Centrón, 2009a), EB \\
\hline North Yboty & $23^{\circ} 43^{\prime} S$ & $56^{\circ} 18^{\prime} \mathrm{W}$ & 0 & $E B$ \\
\hline Nueva Germania & $23^{\circ} 54^{\prime} S$ & $56^{\circ} 34^{\prime} \mathrm{W}$ & $S$ & ZSM, (Laubmann, 1940) \\
\hline Señorita & $23^{\circ} 45^{\prime} S$ & $56^{\circ} 13^{\prime} \mathrm{W}$ & 0 & $E B$ \\
\hline \multicolumn{5}{|l|}{ Presidente Hayes } \\
\hline Benjamín Aceval, Villa Hayes & $25^{\circ} 06^{\prime} \mathrm{S}$ & $57^{\circ} 34^{\prime} \mathrm{W}$ & $S$ & MHNSCP, (Bertoni, 1930) \\
\hline Estancia La Rafaela & $24^{\circ} 53^{\prime} \mathrm{S}$ & $57^{\circ} 27^{\prime} \mathrm{W}$ & 0 & $E B$ \\
\hline Monte Sociedad & $25^{\circ} 03^{\prime} \mathrm{S}$ & $57^{\circ} 35^{\prime} \mathrm{W}$ & $S$ & (Laubmann, 1940) \\
\hline Pirizal area, Catholic Mission & $22^{\circ} 13^{\prime} S$ & $58^{\circ} 25^{\prime} \mathrm{W}$ & 0 & $E B$ \\
\hline Ruta Transchaco, km 20 to 79 & $24^{\circ} 48^{\prime} S$ & $57^{\circ} 46^{\prime} \mathrm{W}$ & 0 & $E B$ \\
\hline Ruta Transchaco, km 60 & $24^{\circ} 55^{\prime} \mathrm{S}$ & $57^{\circ} 38^{\prime} \mathrm{W}$ & 0 & (Hayes, 1995) \\
\hline \multicolumn{5}{|l|}{ Cordillera } \\
\hline Arroyos y Esteros, km 100 & $24^{\circ} 52^{\prime} \mathrm{S}$ & $56^{\circ} 53^{\prime} \mathrm{W}$ & 0 & $E B$ \\
\hline Estancia Sombrero & $25^{\circ} 01^{\prime} \mathrm{S}$ & $56^{\circ} 35^{\prime} \mathrm{W}$ & 0 & $E B$ \\
\hline \multicolumn{5}{|l|}{ Paraguarí } \\
\hline Agromonte & $25^{\circ} 43^{\prime} \mathrm{S}$ & $57^{\circ} 06^{\prime} \mathrm{W}$ & 0 & $E B$ \\
\hline Estancia Barrerito & $26^{\circ} 16^{\prime} S$ & $57^{\circ} 03^{\prime} \mathrm{W}$ & 0 & (Centrón, 2009c), EB \\
\hline Sapucái & $25^{\circ} 40^{\prime} \mathrm{S}$ & $56^{\circ} 55^{\prime} \mathrm{W}$ & $S$ & NHMUK, (Chubb, 1910) \\
\hline \multicolumn{5}{|l|}{ Concepción } \\
\hline Arroyo Tagatiya, Campos Cerrados & $22^{\circ} 44^{\prime} S$ & $57^{\circ} 33^{\prime} \mathrm{W}$ & 0 & $E B$ \\
\hline Cerrados de Concepción & $22^{\circ} 25^{\prime} \mathrm{S}$ & $57^{\circ} 10^{\prime} \mathrm{W}$ & 0 & $E B$ \\
\hline Estancia San Luis de La Sierra, Arroyo La Paz & $22^{\circ} 23^{\prime} \mathrm{S}$ & $57^{\circ} 27^{\prime} \mathrm{W}$ & 0 & $E B$ \\
\hline Serranía San Luis National Park & $22^{\circ} 36^{\prime} S$ & $57^{\circ} 25^{\prime} \mathrm{W}$ & 0 & $E B$ \\
\hline Zanja Moroti, Río Apa & $22^{\circ} 30^{\prime} S$ & $57^{\circ} 00^{\prime} \mathrm{W}$ & $S$ & ZSM, (Laubmann, 1940) \\
\hline \multicolumn{5}{|l|}{ Canindeyú } \\
\hline Aguara Ñú & $24^{\circ} 11^{\prime} S$ & $55^{\circ} 16^{\prime} \mathrm{W}$ & $P$ & $\mathrm{~EB}, \mathrm{XC}$ \\
\hline Reserva Natural del Bosque Mbaracayú & $24^{\circ} 06^{\prime} S$ & $55^{\circ} 14^{\prime} \mathrm{W}$ & 0 & (Madroño Nieto \& Esquivel, 1997), EB \\
\hline \multicolumn{5}{|l|}{ Caaguazú } \\
\hline Morombi & $24^{\circ} 37^{\prime} \mathrm{S}$ & $55^{\circ} 22^{\prime} \mathrm{W}$ & 0 & $E B$ \\
\hline Upper Iguazú River & $25^{\circ} 05^{\prime} \mathrm{S}$ & $55^{\circ} 45^{\prime} \mathrm{W}$ & $S$ & AMNH \\
\hline \multicolumn{5}{|l|}{ Caazapá } \\
\hline Arrozal Codas & $26^{\circ} 29^{\prime} S$ & $56^{\circ} 18^{\prime} \mathrm{W}$ & 0 & $E B$ \\
\hline Estancia Roa Coé & $26^{\circ} 33^{\prime} S$ & $56^{\circ} 06^{\prime} \mathrm{W}$ & 0 & (Codesido \& Fraga, 2009) \\
\hline Estancia Tapyta & $26^{\circ} 14^{\prime} S$ & $55^{\circ} 46^{\prime} \mathrm{W}$ & 0 & $\mathrm{~EB}, \mathrm{XC}$ \\
\hline San Juan Nepomuceno & $26^{\circ} 08^{\prime} S$ & $55^{\circ} 56^{\prime} \mathrm{W}$ & 0 & $E B$ \\
\hline \multicolumn{5}{|l|}{ Itapúa } \\
\hline Carmen del Paraná & $27^{\circ} 15^{\prime} \mathrm{S}$ & $56^{\circ} 08^{\prime} \mathrm{W}$ & 0 & (Codesido \& Fraga, 2009) \\
\hline Coronel Bogado, Fundación San Rafael & $27^{\circ} 07^{\prime} \mathrm{S}$ & $56^{\circ} 22^{\prime} \mathrm{W}$ & 0 & $E B$ \\
\hline Dr. Blas Garay & $26^{\circ} 46^{\prime} S$ & $56^{\circ} 16^{\prime} W$ & 0 & $E B$ \\
\hline Estero San José & $26^{\circ} 55^{\prime} \mathrm{S}$ & $56^{\circ} 04^{\prime} \mathrm{W}$ & 0 & (Bonzi et al., 2020) \\
\hline General Artigas, Estero Ñu Guasu & $26^{\circ} 56^{\prime} \mathrm{S}$ & $56^{\circ} 18^{\prime} \mathrm{W}$ & 0 & (Bonzi et al., 2020), EB \\
\hline Isla Yacyretá Natural Reserve & $27^{\circ} 25^{\prime} S$ & $56^{\circ} 43^{\prime} \mathrm{W}$ & 0 & (Codesido \& Fraga, 2009), (Bonzi et al., 2020), EB \\
\hline La Paz Fish Farm & $27^{\circ} 00^{\prime} S$ & $55^{\circ} 54^{\prime} \mathrm{W}$ & $P$ & $E B$ \\
\hline Leandro Oviedo & $26^{\circ} 43^{\prime} S$ & $56^{\circ} 16^{\prime} \mathrm{W}$ & 0 & $E B$ \\
\hline San Miguel Potrero & $27^{\circ} 03^{\prime} S$ & $56^{\circ} 08^{\prime} \mathrm{W}$ & 0 & (Bonzi et al., 2020) \\
\hline San Rafael, Guyra Reta Reserve, Kanguery Biological Station & $26^{\circ} 30^{\prime} \mathrm{S}$ & $55^{\circ} 46^{\prime} \mathrm{W}$ & 0 & (del Castillo \& Centrón, 2010), EB \\
\hline San Rafael National Park, Estancia Kanguery & $26^{\circ} 25^{\prime} \mathrm{S}$ & $55^{\circ} 48^{\prime} \mathrm{W}$ & 0 & (Esquivel-M. et al., 2007), (Smith, 2017), EB \\
\hline \multicolumn{5}{|l|}{ Misiones } \\
\hline Campo Llano & $26^{\circ} 47^{\prime} \mathrm{S}$ & $57^{\circ} 25^{\prime} \mathrm{W}$ & 0 & (Centrón \& del Castillo, 2011), EB \\
\hline Estancia La Graciela & $26^{\circ} 31^{\prime} \mathrm{S}$ & $56^{\circ} 52^{\prime} \mathrm{W}$ & 0 & (Centrón, 2009b), (Ferreira, 2009), EB \\
\hline Santiago & $27^{\circ} 05^{\prime} S$ & $56^{\circ} 50^{\prime} \mathrm{W}$ & 0 & $E B$ \\
\hline Yabebyry & $27^{\circ} 13^{\prime} S$ & $56^{\circ} 56^{\prime} \mathrm{W}$ & 0 & $\mathrm{~EB}$ \\
\hline \multicolumn{5}{|l|}{ ARGENTINA } \\
\hline \multicolumn{5}{|l|}{ Misiones } \\
\hline Campo Prates, Barra Concepción & $28^{\circ} 07^{\prime} S$ & $55^{\circ} 35^{\prime} \mathrm{W}$ & 0 & (Krauczuk, 2005) \\
\hline Candelaria, Estancia Santa Cecília & $27^{\circ} 27^{\prime} \mathrm{S}$ & $55^{\circ} 42^{\prime} \mathrm{W}$ & $P$ & $E B$ \\
\hline Candelaria, Puerto San Juan Private Reserve & $27^{\circ} 21^{\prime} \mathrm{S}$ & $55^{\circ} 37^{\prime} \mathrm{W}$ & 0 & (Krauczuk, 2005) \\
\hline Candelaria, Santa Ana, Campo San Juan Reserve & $27^{\circ} 24^{\prime} S$ & $55^{\circ} 37^{\prime} \mathrm{W}$ & $P$ & (Krauczuk, 1997), (Di Giacomo et al., 2007), EB \\
\hline Candelaria, Urutaú Reserve & $27^{\circ} 29^{\prime} S$ & $55^{\circ} 46^{\prime} \mathrm{W}$ & $P$ & $E B$ \\
\hline Capital, Garupá, near Barrio Santa Helena & $27^{\circ} 28^{\prime} S$ & $55^{\circ} 53^{\prime} \mathrm{W}$ & 0 & (Krauczuk, 2005, 2006) \\
\hline
\end{tabular}




\begin{tabular}{|c|c|c|c|c|}
\hline Country, State/Province/Departament, Municipality, Locality & Latitude & Longitude & Record & Source \\
\hline Capital, Posadas, airport & $27^{\circ} 23^{\prime} S$ & $55^{\circ} 57^{\prime} \mathrm{W}$ & 0 & $E B$ \\
\hline Capital, Posadas, Campus of Universidad Nacional de Misiones & $27^{\circ} 26^{\prime} S$ & $55^{\circ} 53^{\prime} \mathrm{W}$ & 0 & (Krauczuk, 2005) \\
\hline Capital, Posadas, Don Lorenzo Refuge & $27^{\circ} 25^{\prime} \mathrm{S}$ & $55^{\circ} 52^{\prime} \mathrm{W}$ & 0 & (Krauczuk, 2005, 2006) \\
\hline Capital, Posadas, international bridge Posadas-Encarnación, El Zaimám creek confluence & $27^{\circ} 22^{\prime} \mathrm{S}$ & $55^{\circ} 53^{\prime} \mathrm{W}$ & 0 & (Krauczuk, 2006) \\
\hline Capital, Posadas, Itaembé Guazú & $27^{\circ} 25^{\prime} \mathrm{S}$ & $55^{\circ} 58^{\prime} \mathrm{W}$ & $P$ & $E B$ \\
\hline Capital, Posadas, mouth of Mártires river & $27^{\circ} 23^{\prime} \mathrm{S}$ & $55^{\circ} 57^{\prime} \mathrm{W}$ & $P$ & $E B$ \\
\hline Capital, Posadas, near the Ruínas de Mártires & $27^{\circ} 25^{\prime} \mathrm{S}$ & $55^{\circ} 56^{\prime} \mathrm{W}$ & 0 & (Krauczuk, 2005) \\
\hline Capital, Posadas, Nemesio Parma, Paraíso Costero & $27^{\circ} 20^{\prime} \mathrm{S}$ & $56^{\circ} 01^{\prime} \mathrm{W}$ & $P$ & $E B$ \\
\hline Capital, Posadas, Santa Rosa Private Reserve & $27^{\circ} 24^{\prime} S$ & $55^{\circ} 53^{\prime} \mathrm{W}$ & 0 & (Krauczuk, 2005) \\
\hline Capital, Posadas, west access to Posadas & $27^{\circ} 22^{\prime} \mathrm{S}$ & $55^{\circ} 57^{\prime} \mathrm{W}$ & 0 & (Krauczuk, 2006) \\
\hline Concepción, Cerro Mártires y Barra Santa María & $27^{\circ} 51^{\prime} S$ & $55^{\circ} 26^{\prime} \mathrm{W}$ & 0 & (Di Giacomo et al., 2007) \\
\hline Concepción de la Sierra, Barra Concepción & $28^{\circ} 08^{\prime} S$ & $55^{\circ} 53^{\prime} \mathrm{W}$ & $S$ & MACN, (Di Giacomo et al., 2007) \\
\hline Garupá creek basin & $27^{\circ} 29^{\prime} \mathrm{S}$ & $55^{\circ} 44^{\prime} \mathrm{W}$ & 0 & (Di Giacomo et al., 2007) \\
\hline Near Río Saimá, Itapua & $27^{\circ} 22^{\prime} \mathrm{S}$ & $55^{\circ} 58^{\prime} \mathrm{W}$ & $S$ & (White, 1882) \\
\hline \multicolumn{5}{|l|}{ Chaco } \\
\hline Bermejo, El Cachapé & $26^{\circ} 50^{\prime} \mathrm{S}$ & $59^{\circ} 00^{\prime} \mathrm{W}$ & 0 & (Di Giacomo et al., 2007) \\
\hline Bermejo, Sol de Mayo & $26^{\circ} 59^{\prime} S$ & $58^{\circ} 42^{\prime} \mathrm{W}$ & $P$ & $E B$ \\
\hline \multicolumn{5}{|l|}{ Corrientes } \\
\hline Capital, Estero Valenzuela & $27^{\circ} 53^{\prime} \mathrm{S}$ & $58^{\circ} 34^{\prime} \mathrm{W}$ & 0 & (Di Giacomo et al., 2007) \\
\hline Concepción and San Roque, Concepcíon - Chavarría & $28^{\circ} 37^{\prime} S$ & $58^{\circ} 10^{\prime} \mathrm{W}$ & 0 & (Di Giacomo et al., 2007) \\
\hline Estancia Puerto Valle & $27^{\circ} 43^{\prime} \mathrm{S}$ & $56^{\circ} 29^{\prime} \mathrm{W}$ & 0 & (Parera, 2004) \\
\hline General Alvear, Bañado San Isidoro & $28^{\circ} 54^{\prime} S$ & $56^{\circ} 36^{\prime} \mathrm{W}$ & 0 & $E B$ \\
\hline General Paz, Lomas de Vallejos, Ruta Provincial 5 & $27^{\circ} 43^{\prime} \mathrm{S}$ & $58^{\circ} 01^{\prime} \mathrm{W}$ & 0 & $E B$ \\
\hline Gobernador General Virasoro, Estancia La Higuera & $27^{\circ} 59^{\prime} S$ & $56^{\circ} 18^{\prime} \mathrm{W}$ & 0 & (Marino et al., 2013) \\
\hline Gobernador General Virasoro, Estancia Virocay & $28^{\circ} 15^{\prime} S$ & $55^{\circ} 57^{\prime} \mathrm{W}$ & 0 & (Marino et al., 2013), EB \\
\hline Gobernador General Virasoro, Las Marías & $28^{\circ} 06^{\prime} S$ & $56^{\circ} 03^{\prime} \mathrm{W}$ & 0 & (Krauczuk, 2005), EB \\
\hline Gobernador General Virasoro, Sosa Cué & $28^{\circ} 00^{\prime} \mathrm{S}$ & $56^{\circ} 02^{\prime} \mathrm{W}$ & 0 & $E B$ \\
\hline Iberá Provincial Reserve & $28^{\circ} 24^{\prime} S$ & $57^{\circ} 07^{\prime} \mathrm{W}$ & 0 & (Chebez et al., 1999) \\
\hline Ituzaingó, Estancia La Guayna & $27^{\circ} 45^{\prime} \mathrm{S}$ & $56^{\circ} 04^{\prime} \mathrm{W}$ & 0 & (Codesido \& Fraga, 2009) \\
\hline Ituzaingó, Iberá National Park, Cambyretá & $27^{\circ} 49^{\prime} \mathrm{S}$ & $56^{\circ} 50^{\prime} \mathrm{W}$ & 0 & $E B$ \\
\hline Ituzaingó, Isla Apipé Grande Natural Reserve & $27^{\circ} 30^{\prime} \mathrm{S}$ & $56^{\circ} 52^{\prime} \mathrm{W}$ & 0 & (Esteban, 1953) \\
\hline Ituzaingó, Lomada de San Alonso, Esteros del Iberá & $28^{\circ} 14^{\prime} S$ & $57^{\circ} 24^{\prime} \mathrm{W}$ & 0 & $E B$ \\
\hline Ituzaingó, Puerto Valle & $27^{\circ} 43^{\prime} \mathrm{S}$ & $56^{\circ} 30^{\prime} \mathrm{W}$ & 0 & $E B$ \\
\hline Ituzaingó, Rincón de Santa María Natural Reserve & $27^{\circ} 30^{\prime} \mathrm{S}$ & $56^{\circ} 35^{\prime} \mathrm{W}$ & $P$ & (Krauczuk, 2005), (Di Giacomo et al., 2007), XC, EB \\
\hline Ituzaingó, San Carlos, Rio Aguapey, Estancia San Joaquín & $27^{\circ} 45^{\prime} \mathrm{S}$ & $55^{\circ} 54^{\prime} \mathrm{W}$ & $S$ & MACN, (Darrieu \& Camperi, 1992) \\
\hline Isla Apipé Grande & $27^{\circ} 30^{\prime} S$ & $56^{\circ} 52^{\prime} \mathrm{W}$ & 0 & (Esteban, 1953) \\
\hline Mburucuyá, Mburucuyá National Park & $28^{\circ} 00^{\prime} S$ & $58^{\circ} 05^{\prime} \mathrm{W}$ & 0 & (Chebez et al., 1999), (Di Giacomo et al., 2007), EB \\
\hline Mburucuyá, Mburucuyá village and surroundings & $28^{\circ} 02^{\prime} S$ & $58^{\circ} 13^{\prime} \mathrm{W}$ & 0 & $E B$ \\
\hline Mercedes and San Martín, Rincón del Socorro and Iberá & $28^{\circ} 32^{\prime} \mathrm{S}$ & $57^{\circ} 10^{\prime} \mathrm{W}$ & 0 & (Di Giacomo et al., 2007), EB \\
\hline San Martín, Colonia Carlos Pellegrini & $28^{\circ} 32^{\prime} S$ & $57^{\circ} 10^{\prime} \mathrm{W}$ & 0 & EB \\
\hline San Miguel, Estancia San Juan Poriahú & $27^{\circ} 42^{\prime} S$ & $57^{\circ} 11^{\prime} \mathrm{W}$ & 0 & EB \\
\hline Santo Tomé, Estancia Mora Cué and around & $28^{\circ} 18^{\prime} S$ & $56^{\circ} 10^{\prime} \mathrm{W}$ & 0 & (Di Giacomo et al., 2007) \\
\hline Santo Tomé, far northeast Corrientes & $28^{\circ} 27^{\prime} S$ & $55^{\circ} 47^{\prime} \mathrm{W}$ & 0 & (Di Giacomo et al., 2007) \\
\hline Santo Tomé, Río Aguapey basin & $28^{\circ} 36^{\prime} S$ & $56^{\circ} 56^{\prime} \mathrm{W}$ & 0 & (Di Giacomo et al., 2007) \\
\hline Santo Tomé, Ruta Provincial 40 & $28^{\circ} 22^{\prime} \mathrm{S}$ & $56^{\circ} 07^{\prime} \mathrm{W}$ & 0 & $E B$ \\
\hline Santo Tomé, Ruta Provincial 41 & $28^{\circ} 11^{\prime} \mathrm{S}$ & $56^{\circ} 43^{\prime} \mathrm{W}$ & 0 & $E B$ \\
\hline \multicolumn{5}{|l|}{ Entre Ríos } \\
\hline Colón, Arroyo Caraballo & $32^{\circ} 13^{\prime} \mathrm{S}$ & $58^{\circ} 08^{\prime} W$ & 0 & (Milat et al., 1985) \\
\hline Ibicuy, Ceibas & $33^{\circ} 26^{\prime} \mathrm{S}$ & $58^{\circ} 45^{\prime} \mathrm{W}$ & 0 & (Di Giacomo et al., 2007) \\
\hline \multicolumn{5}{|l|}{ Formosa } \\
\hline Laishi, El Bagual Reserve & $26^{\circ} 10^{\prime} \mathrm{S}$ & $58^{\circ} 56^{\prime} \mathrm{W}$ & $P$ & (Di Giacomo, 1996, 2005), EB \\
\hline Riacho Pilaga & $26^{\circ} 05^{\prime} S$ & $57^{\circ} 59^{\prime} \mathrm{W}$ & $S$ & USNM, (Wetmore, 1926) \\
\hline Río Pilcomayo National Park & $25^{\circ} 04^{\prime} \mathrm{S}$ & $58^{\circ} 07^{\prime} \mathrm{W}$ & $S$ & (Chebez et al., 1999) \\
\hline \multicolumn{5}{|l|}{ Santa Fe } \\
\hline Gral. Obligado y Vera, wooded wedge of Santa Fe & $28^{\circ} 30^{\prime} \mathrm{S}$ & $59^{\circ} 30^{\prime} \mathrm{W}$ & 0 & (Di Giacomo et al., 2007) \\
\hline Mocovi & $28^{\circ} 24^{\prime} S$ & $59^{\circ} 42^{\prime} \mathrm{W}$ & $S$ & AMNH, (Hartert \& Venturi, 1909) \\
\hline San Martín, Provincial Reserve for Multiple Uses Federico Wildermuth & $32^{\circ} 00^{\prime} \mathrm{S}$ & $61^{\circ} 42^{\prime} \mathrm{W}$ & 0 & (Di Giacomo et al., 2007) \\
\hline Tacuarendi & $28^{\circ} 25^{\prime} \mathrm{S}$ & $59^{\circ} 18^{\prime} \mathrm{W}$ & 0 & (Lillo, 1909) \\
\hline Villa Ocampo & $28^{\circ} 28^{\prime} S$ & $59^{\circ} 22^{\prime} \mathrm{W}$ & $S$ & AMNH, (Hartert \& Venturi, 1909) \\
\hline \multicolumn{5}{|l|}{ URUGUAY } \\
\hline \multicolumn{5}{|l|}{ Rivera } \\
\hline Near La Palma, Valle del Lunarejo & $31^{\circ} 10^{\prime} \mathrm{S}$ & $55^{\circ} 55^{\prime} \mathrm{W}$ & $P$ & (Azpiroz, 1998) \\
\hline
\end{tabular}




\title{
APPENDIX 2
}

Specimens of Culicivora caudacuta.

BRAZIL

\section{Amazonas:}

MZUSP 92411, ơ', Igarapé Assuã, BR 319, Canutama, 07.xii.2011, Fábio Schunck \& Bret Whitney.

MZUSP 92412, ơ', Igarapé Assuã, BR 319, Canutama, 07.xii.2011, Fábio Schunck \& Bret Whitney.

MZUSP 92413, ?, Igarapé Assuã, BR 319, Canutama, 07.xii.2011, Fábio Schunck \& Bret Whitney.

\section{Maranhão:}

MPEG 43519, ơ', Estiva, Alto Parnaíba, 03.iv.1989, Brígida, Rosemiro, J.M. Rosa, Raimundo \& Dionísio.

\section{Distrito Federal:}

MNRJ 28988, , Parque Guará, Brasília, 11.x.1963, Luiz Moojen.

MNRJ 28989, ơ', Parque Guará, Brasília, 11.x.1963, Luiz Moojen.

MNRJ 28990, ơ', Parque Guará, Brasília, 11.x.1963, Luiz Moojen.

MNRJ 28991, ơ', Parque Guará, Brasília, 11.x.1963, Luiz Moojen.

MNRJ 32662, ơ', Parque Nacional de Brasília, Brasília, 02.xii.1978, Helmut Sick.

MNRJ 32663, + , Parque Nacional de Brasília, Brasília, 02.xii.1978, Helmut Sick.

IBGE 719, ơ", Cristo Redentor, RECOR, Brasília, 04.vii.1984.

IBGE 720, \&, Cristo Redentor, RECOR, Brasília, 04.vii.1984.

\section{Goiás:}

MNRJ 13218, ơ, Planaltina, 15.vi.1927, Emilie Snethlage.

MNRJ 13219, ᄋ, Planaltina, 15.vi.1927, Emilie Snethlage.

\section{Mato Grosso:}

AMNH 33317, $\$$, Chapada, 13.iv.1883, Herbert Smith.

NHMUK 1889.1.10.299, ㅇ, Chapada, 17.x.1883, Herbert Smith.

\section{Mato Grosso do Sul:}

MZUSP 13211, , Fazenda Monte Verde, Coxim, 29.vi.1930, João Leonardo Lima.

MZUSP 17391, ๆ, Fazenda Monte Verde, Coxim, 08.viii.1937, José Leonardo de Lima.

MCZ 154615, \&, Coxim, 29.vi.1930, João Leonardo Lima.

MCZ 154616, ơ", Coxim, 10.vii.1930, João Leonardo Lima.

MCZ 154617, \&, Fazenda Monte Verde, Coxim, 10.vii.1930, João Leonardo Lima.

FMNH 17390, ơ, Fazenda Recreio, Coxim, 09.viii.1937, José Leonardo de Lima.

\section{Minas Gerais:}

DZUFMG 4511, ơ", Retiro das Pedras, Nova Lima, 02.vi.2005, Marcelo Ferreira de Vasconcelos, Diego Hoffmann, Leonardo Esteves Lopes \& Éverton Vieira Ouriques. DZUFMG 4512, $\subsetneq$, Retiro das Pedras, Nova Lima, 02.vi.2005, Marcelo Ferreira de Vasconcelos, Diego Hoffmann, Leonardo Esteves Lopes \& Éverton Vieira Ouriques. MCNA 2211, o', Retiro das Pedras, Nova Lima, 02.vi.2005, Marcelo Ferreira de Vasconcelos, Diego Hoffmann, Leonardo Esteves Lopes \& Éverton Vieira Ouriques. MCNA 2277, ९, Retiro das Pedras, Nova Lima, 02.vi.2005, Marcelo Ferreira de Vasconcelos, Diego Hoffmann, Leonardo Esteves Lopes \& Éverton Vieira Ouriques. MZUSP 115128, headwaters of Córrego do Fundão, Patrocínio, 22.x.2015, Luís Fábio Silveira \& Robson Silva e Silva.

MZUSP 115129, Fazenda Todos os Santos, headwaters of Córrego Capoeira Grande, Patrocínio, 19.viii.2020, Robson Silva e Silva \& Lucio dos Reis Oliveira. MZUSP 115130, headwaters of Córrego Bebedouro, Patrocínio, 30.v.2021, Robson Silva e Silva, Paulo César Araújo dos Santos-Jr. \& Lucio dos Reis Oliveira. MZUSP 115131, headwaters of Córrego Bebedouro, Patrocínio, 30.v.2021, Robson Silva e Silva, Paulo César Araújo dos Santos-Jr. \& Lucio dos Reis Oliveira. MZUSP 115132, headwaters of Córrego Bebedouro, Patrocínio, 30.v.2021, Robson Silva e Silva, Paulo César Araújo dos Santos-Jr. \& Lucio dos Reis Oliveira. MZUSP 115133, headwaters of Córrego Bebedouro, Patrocínio, 30.v.2021, Robson Silva e Silva, Paulo César Araújo dos Santos-Jr. \& Lucio dos Reis Oliveira.

\author{
São Paulo: \\ NMW 17817, ơ', Scaramuza, Itararé, 20.viii.1820, Johann Natterer. \\ NMW 17818, o`, Scaramuza, Itararé, 20.viii.1820, Johann Natterer. \\ NMW 17820, ᄋ, Ipanema, 29.v.1819, Johann Natterer. \\ NMW 17821, ơ, Ipanema, 29.v.1819, Johann Natterer. \\ SMF 43938, ?, Ipanema, 29.v.1819, Johann Natterer. \\ NMW 17822, o"', Itararé, 11.ii.1821, Johann Natterer. \\ NHMUK 1888.1.13.331, ơ', Itararé, 11.ii.1821, Johann Natterer.
}


RMNH 88812, $0^{7}$, Itararé, Johann Natterer.

NMW 17823, o', Rio das Pedras, 16.iv.1823, Johann Natterer.

MZUSP 1434, \%, Batatais, 12.xii.1900, João Leonardo Lima.

MZUSP 7995, o', Franca, ix.1910, Ernest Garbe.

MCP 3269, Unidade de Pesquisa e Desenvolvimento de Itararé, Itararé, 26.i.2010, Márcio Repenning.

ZMB 2559, ơ', Santa Lúcia, between 1814 and 1831, Friedrich Sellow.

Paraná:

NMW 17819, o', Curitiba, 29.x.1820, Johann Natterer.

NHMUK 1888.1.13.330, $\sigma^{\prime}, 20 . x i .1820$, Curitiba, Johann Natterer.

MHNCI 5023, o', Quatro Barras, 07.iv.1999, Eduardo Carrano \& Luiz Fernando Franco de Macedo.

MHNCI 5140, ?, Rio Iraí, Quatro Barras, 13.iv.1999, Eduardo Carrano \& Luiz Fernando Franco de Macedo.

MCP 3583, Piraí do Sul, 29.i.2013, Tony Andrey Bichinski Teixeira.

MCP 3584, Piraí do Sul, 29.i.2013, Tony Andrey Bichinski Teixeira.

\section{Santa Catarina:}

MCP 2773, Coxilha Rica, Lages, 03.xii.2009, Márcio Repenning.

MCP 2793, Coxilha Rica, Lages, 12.i.2010, Mariana Lopes Gonçalves.

MCP 3294, Coxilha Rica, Lages, 01.ii.2009, Ismael Franz.

MCP 3689, Coxilha Rica, Lages, 10.ii.2010, Ismael Franz.

\section{Rio Grande do Sul:}

MCP 1845, Várzea do Arroio Moema, Vacaria, 22.xii.2006, Márcio Repenning.

MCP 2110, Banhado do Arroio Água Branca, Bom Jesus, 12.xii.2007, Cristiano Eidt Rovedder.

MCP 2111, Banhado do Arroio Água Branca, Bom Jesus, 24.xii.2007, Cristiano Eidt Rovedder.

MCP 2112, Banhado do Arroio Água Branca, Bom Jesus, 09.i.2008, Cristiano Eidt Rovedder.

MCP 2246, Banhado do Arroio Água Branca, Bom Jesus, 04.iv.2008, Márcio Repenning.

MCP 2265, Banhado do Arroio Água Branca, Bom Jesus, 03.xii.2007, Márcio Repenning.

MCP 2266, Banhado do Arroio Água Branca, Bom Jesus, 07.i.2008, Cristiano Eidt Rovedder.

MCP 3274, Bom Jesus, 08.i.2010, Cristiano Eidt Rovedder.

MCP 3275, Bom Jesus, 08.i.2010, Cristiano Eidt Rovedder.

MCP 3657, Coxilha Grande São Pedro, Vacaria, 16.i.2009, Márcio Repenning.

MCP 3683, Banhado do Arroio Água Branca, Bom Jesus, 14.xii.2009, Cristiano Eidt Rovedder.

MCP 3684, Banhado do Arroio Água Branca, Bom Jesus, 17.xi.2009, Cristiano Eidt Rovedder.

\section{Unknown State}

NHMUK 1888.1.1.433, ?, S.E. Brazil, P.L. Sclater.

ZMB 2560, $\sigma^{7}$, between 1814 and 1831, Friedrich Sellow.

ZMB 2561, $0^{\prime}$, between 1814 and 1831, Friedrich Sellow.

ZSM, S. Brazil, ex. Mus. H. von Leuchtenberg.

\section{BOLIVIA}

El Beni:

LSUMZ 124493, ơ', General Jose Ballivan, 3 km SW San Borja, 06.x.1984, C. Gregory Schmitt.

\section{Santa Cruz:}

ANSP 143068, ơ', Buena Vista, 26.vii.1912, Joseph Steinbach.

CM P43912, \&, Buena Vista, 25.vii.1911, Joseph Steinbach.

CM P43925, ơ', Buena Vista, 26.i.1912, Joseph Steinbach.

CM P51046, o', Buena Vista, 20.xi.1914, Joseph Steinbach.

CM P79126, ơ', Buena Vista, 16.iii.1917, Joseph Steinbach.

LSUMZ 150981, \&, Velasco, Serranía de Huanchaca, 45 km E. Florida, 02.x.1989, Tristan J. Davis.

LSUMZ 150982, ९, Velasco, Serranía de Huanchaca, 45 km E. Florida, 03.x. 1989, John M. Bates.

LSUMZ 150983,, , Velasco, Serranía de Huanchaca, 45 km E. Florida, 03.x.1989, Gary H. Rosenberg.

LSUMZ 150984, + , Velasco, Serranía de Huanchaca, 45 km E. Florida, 04.x.1989, Abel Castillo.

LSUMZ 150985, o", Velasco, Serranía de Huanchaca, 45 km E. Florida, 06.x.1989, Tristan J. Davis.

LSUMZ 150986, o", Velasco, Serranía de Huanchaca, 45 km E. Florida, 12.x.1989, Tristan J. Davis.

LSUMZ 150987, o', Velasco, Serranía de Huanchaca, 45 km E. Florida, 12.x.1989, Gary H. Rosenberg.

LSUMZ 151790, \&, Velasco, Serranía de Huanchaca, 45 km E. Florida, 03.x.1989, Abel Castillo (skeleton specimen). 
LSUMZ 151884, ?, Velasco, Serranía de Huanchaca, 45 km E. Florida, 03.x.1989, Tristan J. Davis (alcoholic specimen). MNK 701, \&, Velasco, Serranía Huanchaca, 45 km E. Florida, 30.ix.1989, Abel Castillo.

\section{PARAGUAY}

Caaguazú:

AMNH 320548, ơ', Upper Iguazú River, 07.i.1931, Emil Kaempfer.

AMNH 320549, \&, Upper Iguazú River, 07.i.1931, Emil Kaempfer.

\section{San Pedro:}

ZSM 32699, ơ', Col. Nueva Germânia, 01.ii.1932, E. Schunmacher.

\section{Presidente Hayes:}

MHNSCP, Benjamin Aceval, Villa Hayes.

? Monte Sociedad.

\section{Paraguarí:}

NHMUK 1905.10.12.364, ơ', Sapucái, 24.iii.1903, William Foster. NHMUK 1905.10.12.365, ơ', Sapucái, 24.vii.1904, William Foster. NHMUK 1905.10.12.366, ơ', Sapucái, 27.vii.1904, William Foster. NHMUK 1905.10.12.367, ơ', Sapucái, 16.viii.1904, William Foster. NHMUK 1905.10.12.368, \%, Sapucái, 16.viii.1904, William Foster.

\section{Concepción:}

ZSM, Zanja Moroti, Río Apa.

\section{ARGENTINA}

\section{Misiones:}

MACN 44769, ơ', Concepción de la Sierra, Barra Concepción. MACN 44771, ơ', Concepción de la Sierra, Barra Concepción.

\section{Corrientes:}

MACN 44770, , Ituzaingó, San Carlos, Río Aguapey, Estancia San Joaquín. MACN 44772, + , Ituzaingó, San Carlos, Río Aguapey, Estancia San Joaquín. MACN 44773, o', Ituzaingó, San Carlos, Río Aguapey, Estancia San Joaquín.

\section{Formosa:}

USNM 227339, , Kilometro 182, Riacho Pilaga, 10 mi NW, 14.viii.1920, Alexander Wetmore. USNM 284426, $\$$, Kilometro 182, Riacho Pilaga, 10 mi NW, 14.viii.1920, Alexander Wetmore. ? Río Pilcomayo National Park.

\section{Santa Fe:}

AMNH 498990, o', Mocovi, 02.xii.1903, Santiago Venturi.

AMNH 498991, ९, Mocovi, 02.xii.1903, Santiago Venturi.

AMNH 435689, o", Villa 0campo, 07.i.1904, Santiago Venturi.

AMNH 498989, o", Villa Ocampo, 01.xi.1905, Santiago Venturi. 